
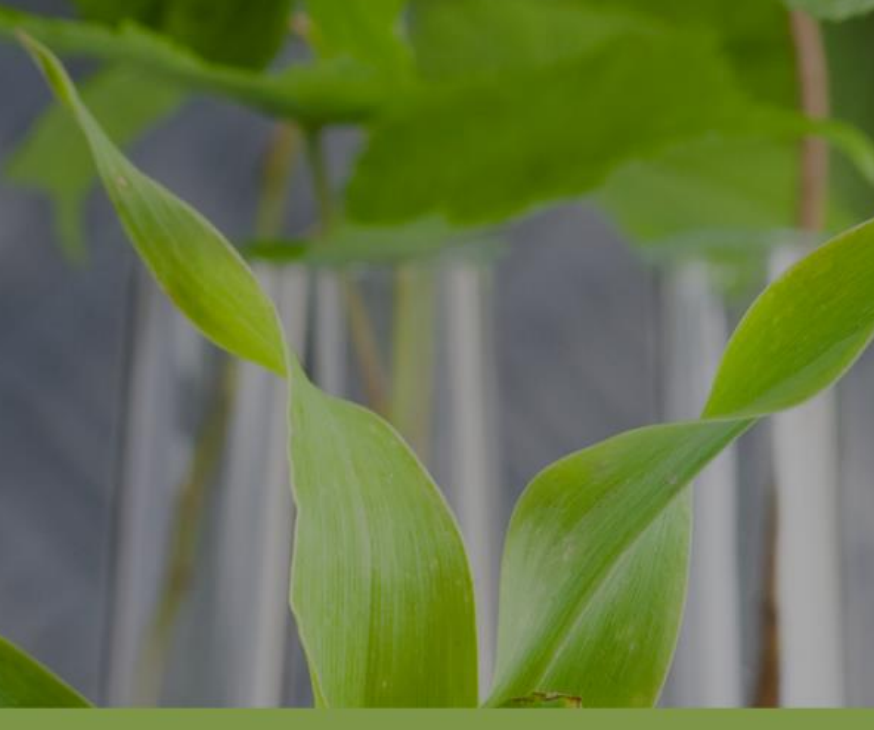

\title{
Biotechnological potential of
} essential oils from native and

\section{cultivated plants in Brazil}

\section{ORGANIZED BY}

SELENE MAIA DE MORAIS
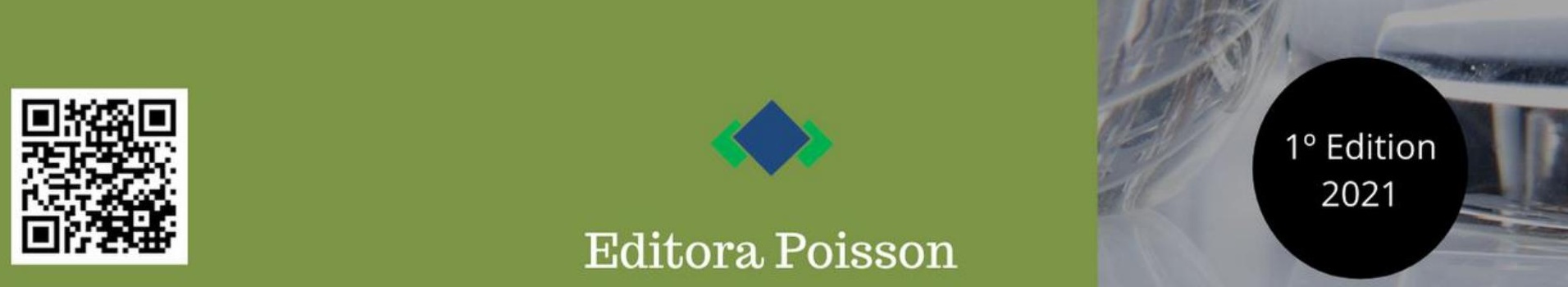

Editora Poisson 
Organized by

Selene Maia de Morais

\section{Biotechnological potential of essential oils from native and cultivated plants in Brazil}




\section{Chief Editor: Dr. Darly Fernando Andrade}

\section{Editorial Board}

Dr. Antônio Artur de Souza - Federal University of Minas Gerais

Ms. Davilson Eduardo Andrade

Dra. Elizângela de Jesus Oliveira - Federal University of Amazonas

Msc. Fabiane dos Santos

Dr. José Eduardo Ferreira Lopes - Federal University of Minas Uberlândia Dr. Otaviano Francisco Neves - Pontifical Catholic University of Minas Gerais

Dr. Luiz Cláudio de Lima - FUMEC University

Dr. Nelson Ferreira Filho - Kennedy Colleges

Ms. Valdiney Alves de Oliveira - Federal University of Minas Uberlândia

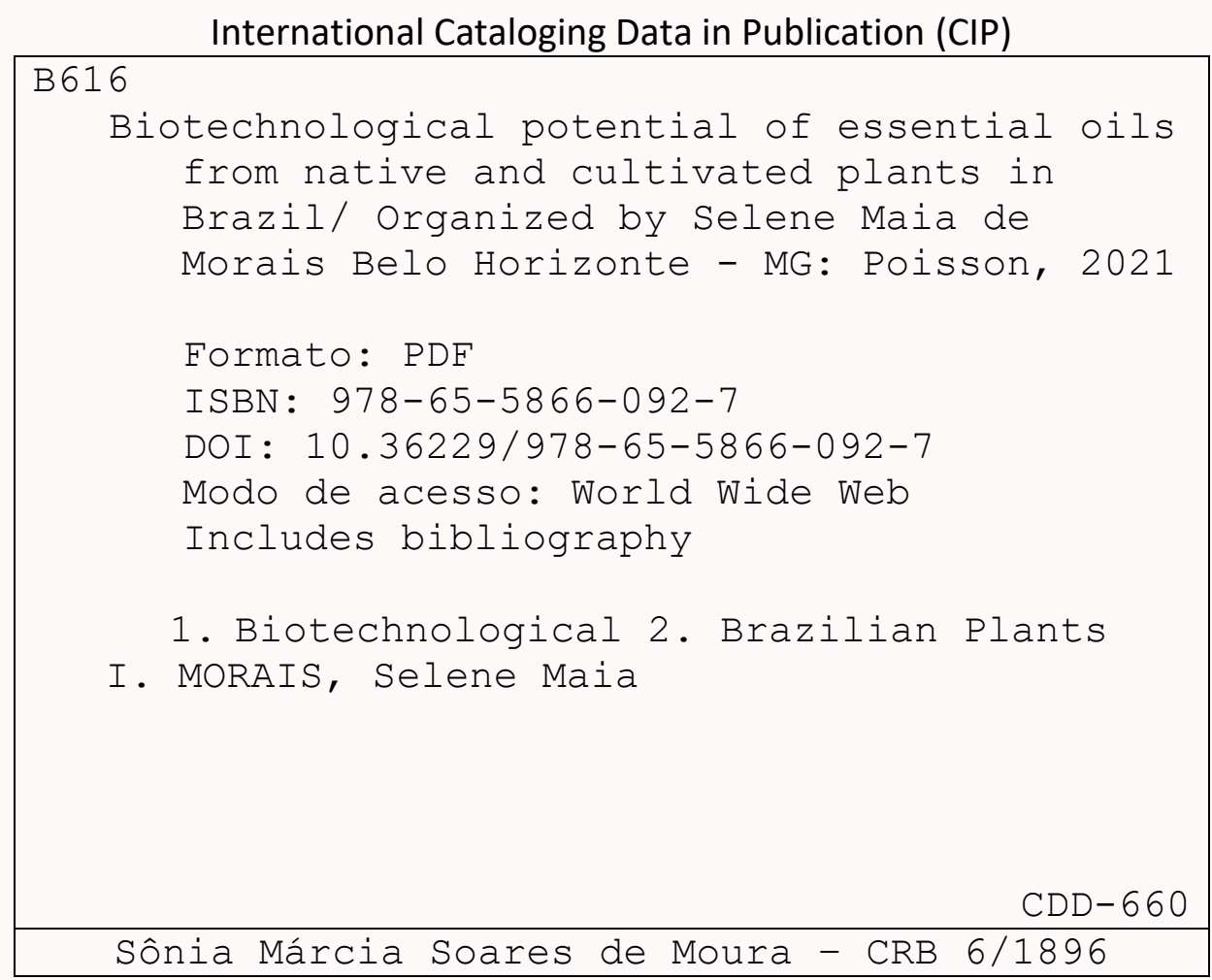

The content of the articles and their data in their form, correctness and reliability are the sole responsibility of their respective authors.

$\underline{\text { www.poisson.com.br }}$

contato@poisson.com.br 
Chapter 1 Chemical composition and bioactivities of essential oils from different chemotypes of Lippia alba (Mill.) N.E.Br. Ex Britton \& P. Wilson

Selene Maia de Morais, Antonio Carlos Nogueira Sobrinho, Hortência Ribeiro Liberato, Rita de Cassia Alves Pereira, Raquel Oliveira dos Santos Fontenelle, Cláudia Pessoa, Elthon Gois Ferreira, Daniela Ribeiro Alves, Ícaro Gusmão Pinto Vieira.

DOI 10.36229/978-65-5866-092-7.CAP.01

Chapter 2 Essential Oils from Curcuma longa and Curcuma zedoaria grown in Brazil as larvicides against Aedes aegypti

Celma de Oliveira Barbosa, Selene Maia de Morais, Icaro Gusmão Pinto Vieira, Rita de Cássia Alves Pereira, Vitor Carvalho Martins, João Francisco Câmara Neto, José Osvaldo Beserra Carioca

DOI 10.36229/978-65-5866-092-7.CAP.02

Chapter 3 Intraspecific variation of the chemical composition and antioxidant and anticholinesterase activities of essential oils and phenolic content of four Croton blanchetianus Baill specimens

Dayane Lima Guerra, Ana Livya Moreira Rodrigues, Daniela Ribeiro Alves, Edilberto Rocha Silveira, Selene Maia de Morais

DOI 10.36229/978-65-5866-092-7.CAP.03

Chapter 4 Chemical composition and antioxidant activity of leaf essential from three Mentha species

Selene Maia de Morais, Alexandre Sousa Barros, Icaro Gusmão Pinto Vieira, Rita de Cassia A. Pereira, Cleonilda Claita C. Pinto, Hortência Ribeiro Liberato

DOI 10.36229/978-65-5866-092-7.CAP.04

Chapter 5 Applications of plant essential oils Selene

Maia de Morais

DOI 10.36229/978-65-5866-092-7.CAP.05

\section{Authors}




\section{PREFACE}

\section{ESSENTIAL OILS FROM PLANTS AND POTENTIALITIES}

Essential oils are liquid extracts from aromatic plants, which have numerous applications in multiple industries. There is a variety of methods used for the extraction of essential oils, like steam distillation, hydro-distillation, and supercritical $\mathrm{CO}_{2}$ which are the most used, each method exhibiting certain advantages and can influence in the biological and physicochemical properties of the extracted oils. Essential oils from different plant species contains many constituents which are comprised of volatile and non-volatile components (Aziz et al., 2018). The biological properties of essential oils as antimicrobial, antileishmanial, insecticidal, anticancer, anti-inflammatory and anti-viral agents is due to their effective and efficient properties.

Essential oils can be defined as either products or mixtures of fragrant substances or as mixtures of fragrant and odorless substances. Essential oils vary greatly, sometimes due to genetic causes, but also because of climate, rainfall, or geographic origin. They are composed principally of lipophilic and highly volatile secondary plant metabolites, principally mono- and sesquiterpenes, but other types of compounds such as allyl, isoallyl phenols and coumarins may also be present. The applications of essential oils are diverse. Widely used in cosmetics and perfumes, they also have medicinal applications due to their therapeutic properties as well as agro-alimentary uses because of their antimicrobial and antioxidant effects (Ríos, 2016).

Many aromatic oils from plants contain a few major constituents, several minor ones and a larger number of trace compounds (called elements in perfumery parlance). It is virtually impossible to totally reconstruct such a complex combination of components which would include all the trace compounds. It is the synergism of the specific combination of hundreds of constituents naturally present in each plant (including trace compounds) that give the essential oils their valuable therapeutic/healing properties (Vankar et al, 2004). 
Essential oils are compounds derived from the secondary metabolism of glucose in plants, being produced for several purposes: 1. aiming at the survival and continuation of the species by the dispersion of pollen, with the production of pheromones (sexual attractants); 2. In defense against pathogens, producing antifungal, antibacterial, anthelmintic compounds and 3. For protection against oxidative stress caused by the environmental conditions through compounds with antioxidant properties. These would be the main functions for the plant.

The chemical composition of essential oil varies many times according to the time of the year (seasonal variation) or along the day (circadian variation) in each species and also depends which organ it comes from because each part of a plant exerts a proper function. In the roots a defense against soil organisms as helminths, fungus and bacteria and in the leaves insect attractants (pheromones) or repellent, formicide, etc.

Several other factors can influence the composition of essential oils, including growth conditions, climate, altitude, soil type, agricultural methods and practices, developmental stage, plant part extracted, and harvesting time.

However, human being uses these secondary metabolites in the food, pharmaceutical and cosmetic industries due to the millenary use of aromatic plants and their essential oils as condiments, spices, antimicrobial, insecticidal and agents to protect stored products (Mejri et al, 2018).

Volatile organic compounds in plants are low molecular weight compounds (below 300 $\mathrm{Da}$ ) and can be found in various plant tissues. In the plant metabolism, glycose produce Acetyl-CoA, which forms mevalonic acid, precursor of terpenes and by the pentose pathway generates shikimic acid leading to arylpropanoid constituents. Figure 1 shows some examples of constituents of essential oils from plants.

The main constituents of essential oils are:

1. Monoterpenes and sesquiterpenes in the form of saturated and unsaturated hydrocarbons and also functionalized with groups as alcohols, ethers, aldehydes and ketones, esters and thiols.

2. Arylpropanoids which suffers reactions of oxidation, reduction and cyclization to form different classes as propenyl-benzenes, allylbenzenes, aromatic aldehydes and coumarins. 
3. Short chain aliphatic alcohols, alkanes, ketones, aldehydes and fatty acid esters. This book shows the composition of essential oils and various activities of several plants. The main activities examined were antioxidant against the radical DPPH (1,1-Diphenyl, 2-picryl-hidrazyl), anticholinesterase, larvicide against Dengue virus vector mosquito Aedes aegypti, antimicrobial (fungus and bacteria), anthelmintic against Haemonchus contortus, main helminth of ovine and caprine in Northeastern Brazil and cytotoxicity against tumor cells.

In general, the information about essential oils in this book are research results of students from undergraduate and post-graduate courses in Ceará State University.

We are thankful for the financial support of FUNCAP (Ceará Foundation for Research Support) and Ceará State Department of Education. To CNPq (National Conseil for Scientific and Technological Development) by the research grant, process number: 308144/2015-5. 
Figure 1. Examples of compounds present in essential oils

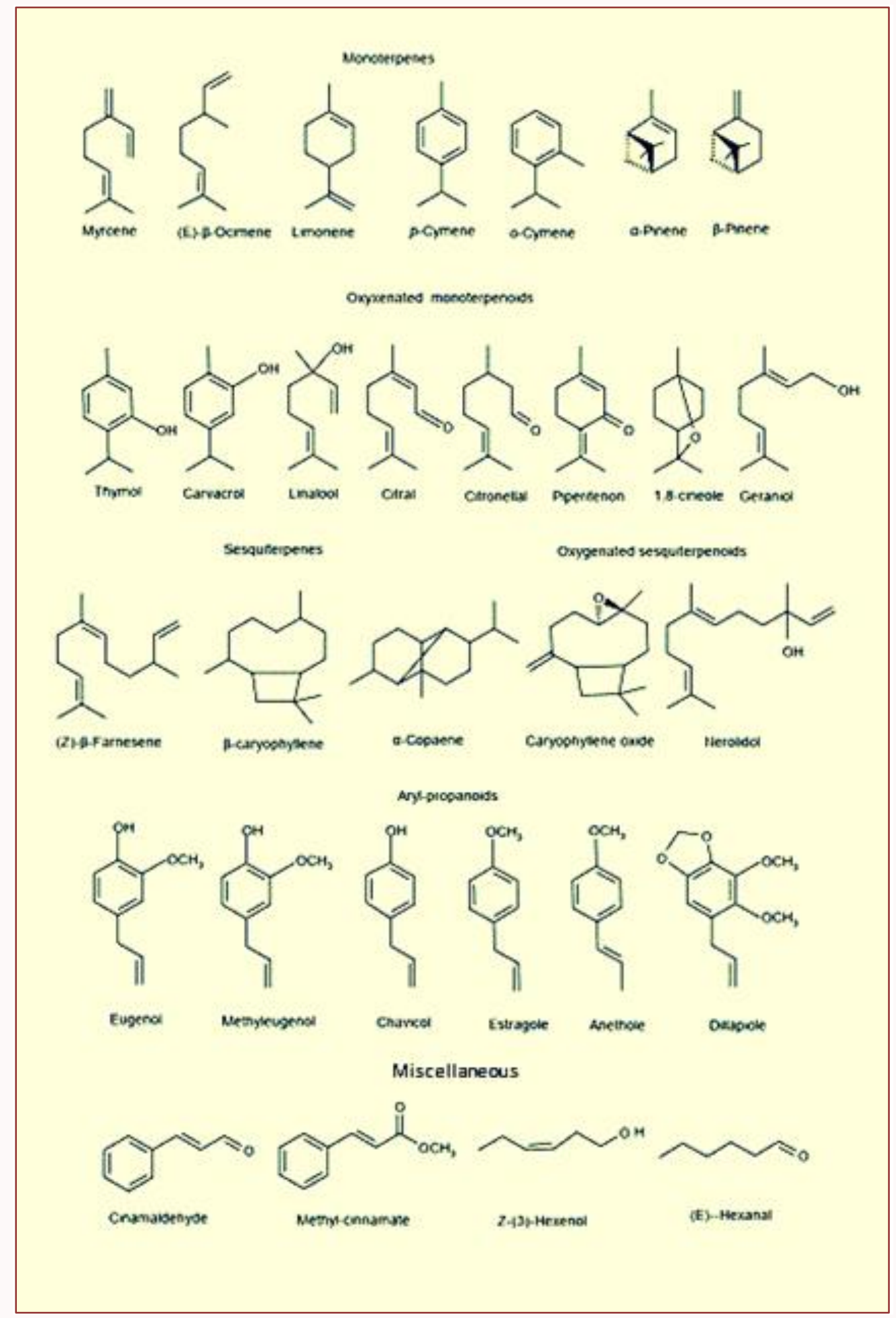




\section{Chapter 1}

Chemical composition and bioactivities of essential oils from different chemotypes of Lippia alba (Mill.) N.E.Br. Ex Britton \& P. Wilson

Selene Maia de Morais,

Antonio Carlos Nogueira Sobrinho

Hortência Ribeiro Liberato

Rita de Cassia Alves Pereira

Raquel Oliveira dos Santos Fontenelle

Cláudia Pessoa, Elthon Gois Ferreira

Daniela Ribeiro Alves

Ícaro Gusmão Pinto Vieira

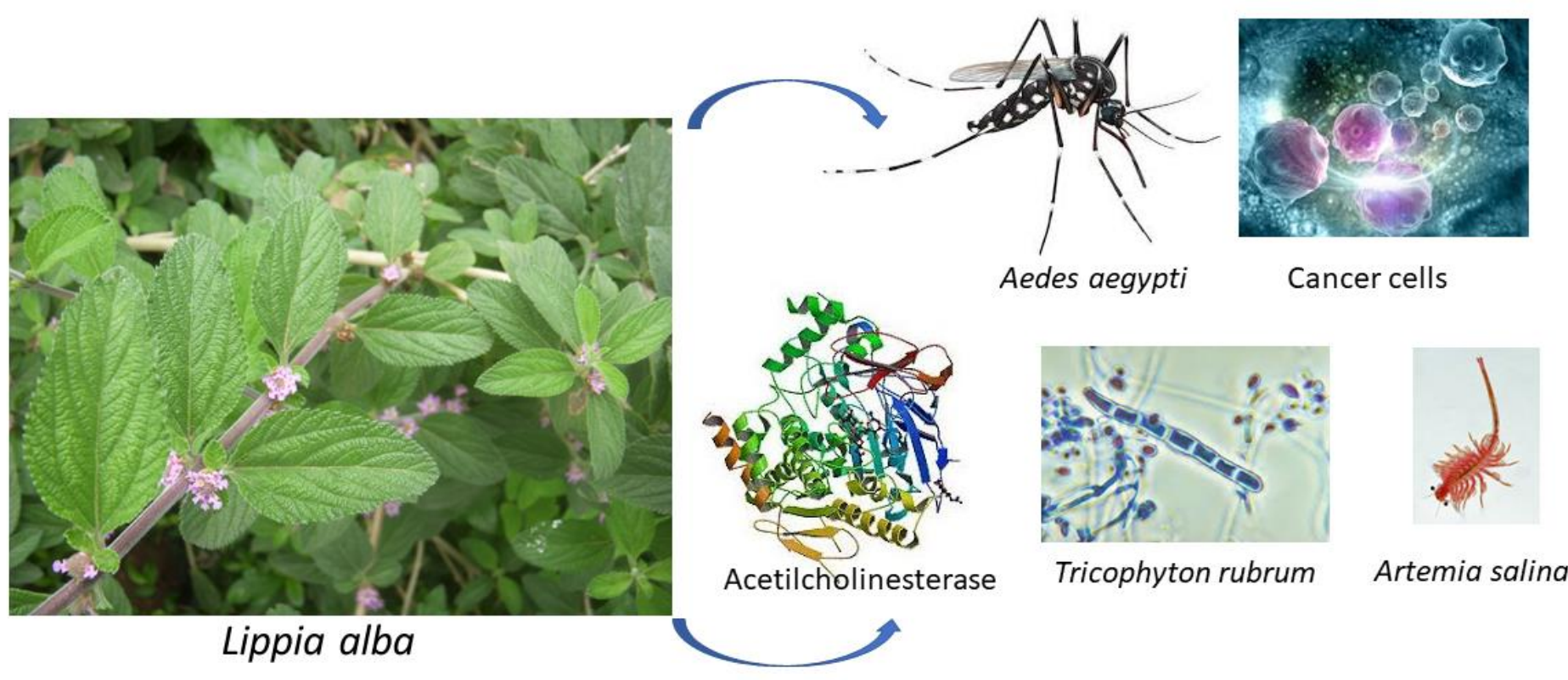




\section{INTRODUCTION}

Lippia alba (Mill.) N.E.Br. ex Britton \& P. Wilson (Verbenaceae family) is a highly branched aromatic shrub with height up to $2 \mathrm{~m}$ (Hennebelle et al., 2008). Popularly known as bushy matgrass, bushy Lippia or lemon balm in English language countries, in Brazil it is variously called erva cidreira, falsa melissa and salvia. It is widely distributed in tropical and subtropical regions, with considerable rates of endemism (Salimena et al., 2016).

Previous studies indicate a large use the $L$. alba by the population including indigenous and rural communities. Infusions made from leaves and aerial parts are used against hypertension, states of excitement, nausea, flu, digestive troubles, colds and pain, as well as topically to heal wounds, and as a syrup against cough and bronchitis (Suárez, 2019; Albuquerque et al., 2007).

Different biological activities, such as antibacterial (Porfírio et al., 2017), antifungal (Mesa-Arango et al., 2009), antiviral (Ocazionez et al., 2010), antigenotoxic (López, Stashenko and Fuentes, 2011), antiprotozoal (Escobar et al., 2010), antioxidant (Stashenko, Jaramillo and Martínez, 2004) and vasorelaxant (Silva et al., 2018), have been identified in L. alba essential oils.

The essential oil of $L$. alba presents varied chemical composition, with great chemical diversity, prompting classification into different chemotypes, such as linalool, carvone, citral, myrcene-camphor, myrcene and limonene-carvone (Matos, 1996; Yamamoto et al., 2008).

Natural products have attracted increasing interest by the pharmaceutical industry due to their medicinal and pharmacological properties, as alternatives to synthetic drugs (Harvey et al., 2015). The larvicidal action of natural products has been useful in the development of bioproducts for the control of arbovirus vectors, such as dengue fever, zika fever, chikungunya fever, yellow fever and Japanese encephalitis, which are serious public health problems in tropical and subtropical regions (Raj et al., 2015; LondonoRenteria, Troupin and Colpitts, 2016).

The acetylcholinesterase (AChE) inhibitory enzyme assay is useful to prospect for molecules with pharmacological action for the treatment of Alzheimer's disease (AliShtayeh et al., 2018). AChE is the major mode of action of most insecticides, such as 
carbamates and organophosphates, and this effect may be responsible for the larvicidal activity against Aedes aegypti and Aedes albopictus (Gade et al., 2017; Mesquita et al., 2018).

This article compares the chemical composition of the volatile oils extracted from seven L. alba chemotypes, and characterizes some biological properties, such as antioxidant and larvicidal against Aedes aegypti and A. albopictus, antifungal against dermatophytes, and cytotoxicity against SNB-19 (astrocytoma), HCT-116 (human colon) and PC-3 (human prostate) cancer cell lines, as well as evaluating these essential oils for the inhibition of acetylcholinesterase, to provide useful information on possible medicinal and other biotechnological applications.

\section{MATERIALS AND METHODS}

Plant collection. Aerial parts of L. alba chemotypes (leaf, inflorescence and stem) were collected in the flowering period in the medicinal plants garden of Embrapa Agroindústria Tropical (Agroindustry Research Unit), Fortaleza, Ceará, Brazil, in August 2016 (latitude 3 45', 47", longitude 38 31' 23" W, altitude 21 m). A voucher specimen (No. EAC59269) was deposited in the Prisco Bezerra Herbarium (EAC) and authenticated by botanist Dr. Maria Iracema Bezerra Loiola of the Department of Biology, Federal University of Ceará. The chemotypes were coded according to their region of origin and culture in Brazil. Embrapa also uses this standard of identification. This study involved the use of seven L. alba chemotypes from different regions of Brazil: LA1, LA2, LA3, LA4, LA5, LA6, LA7, all plants grown at EMBRAPA Tropical Agroindustry (Table 1). 
Table 1. Variety/chemotype of Lippia alba obtained from the experimental garden of Brazilian Agricultural Research Corporation - Embrapa Tropical Agroindustry in Ceará State, Brazil.

Variety/chemotype

\begin{tabular}{|c|c|c|}
\hline LA1 & Atibaia/ São Paulo /Brazil & 0.99 \\
\hline LA2 & São Gonçalo do Rio Abaixo/ Minas Gerais /Brazil & 1.44 \\
\hline LA3 & Botucatu/ São Paulo/ Brazil & 0.72 \\
\hline LA4 & Brasília/ Federal District/ Brazil & 0.61 \\
\hline LA5 & Cruzeiro Grande/ Federal District/ Brazil & 3.31 \\
\hline LA6 & Embrapa/ Cenargem/ Federal District/ Brazil & 1.00 \\
\hline LA7 & Estrutural/ Federal District/ Brazil & 0.63 \\
\hline
\end{tabular}

Extraction of the essential oil. Fresh aerial parts of L. alba (500 g of each chemotype) were submitted to hydrodistillation for $4 \mathrm{~h}$ in a modified Clevenger-type apparatus (Craveiro et al., 1976). The oil was dried over anhydrous $\mathrm{Na}_{2} \mathrm{SO}_{4}(\sim 1 \mathrm{~g})$, filtered and preserved in a sealed vial at $4{ }^{\circ} \mathrm{C}$ prior to further analysis, with different yields of $0.2-2 \%$ $(\mathrm{w} / \mathrm{w})$. The chemical analysis of the essential oil constituents was performed with a Shimadzu QP-2010 Ultra instrument employing the following conditions: Column: Rtx5MS (Crossbond, 5\% diphenyl/95\% dimethyl polysiloxane) measuring $30 \mathrm{~m} \mathrm{x} 0.25 \mathrm{~mm}$ x $0.25 \mu \mathrm{m}$ df; carrier gas: He $(24.2 \mathrm{~mL} / \mathrm{min}$, in constant linear velocity mode); injector temperature of $250^{\circ} \mathrm{C}$, in split mode (1:100); and detector temperature of $250{ }^{\circ} \mathrm{C}$. The column temperature was programmed for $35-180{ }^{\circ} \mathrm{C}$ at $4{ }^{\circ} \mathrm{C} / \mathrm{min}$, then $180-280{ }^{\circ} \mathrm{C}$ at $1{ }^{\circ} \mathrm{C} / \mathrm{min}$, and $280^{\circ} \mathrm{C}$ for $10 \mathrm{~min}$. Mass spectra were obtained at electron impact of 70 $\mathrm{eV}$. The volume of sample injected was $1 \mu \mathrm{L}$. The components were identified from their GC retention times, calculated by linear interpolation relative to retention times of main compounds and by comparison of their mass spectra with those present in the computer data bank and published literature (Adams, 2012; NIST).

Antioxidant test performed by $\beta$-carotene/linoleic acid assay. This test was conducted as described by Lopes-Lutz et al. (2008) and Andrade et al. (2012). The antioxidant potential was determined by measuring the inhibition of the volatile organic compounds and the conjugated diene hydroperoxides resulting from linoleic acid oxidation. A stock solution of emulsion was prepared with $1 \mathrm{mg}$ of $\beta$-carotene dissolved in $5 \mathrm{~mL}$ of chloroform (0.3 mg/mL), $200 \mu \mathrm{L}$ of Tween 40 and $20 \mu \mathrm{L}$ of linoleic acid. Chloroform was completely evaporated using a vacuum evaporator. Then $100 \mathrm{~mL}$ of oxygenated distilled water was added and emulsified for $1 \mathrm{~min}$ in a sonicator to form an emulsion. The 
solution was adjusted in the spectrophotometer $(470 \mathrm{~nm})$. The final emulsion had absorbance between $0.6 \mathrm{~nm}$ and $0.7 \mathrm{~nm}$. Aliquots of $100 \mu \mathrm{L}$ of oil were dissolved in methanol, at concentrations of $500 \mu \mathrm{g} / \mathrm{mL}$ to $25 \mu \mathrm{g} / \mathrm{mL}$, and then added $5 \mathrm{~mL}$ of the $\beta$ carotene/linoleic acid emulsion was added. The samples' absorbance was measured after $2 \mathrm{~min}$, then the samples were subjected to oxidation by placing them in an oven at $50{ }^{\circ} \mathrm{C}$ for $120 \mathrm{~min}$, and a second reading was performed. The same procedure was repeated with the synthetic antioxidant, butylated hydroxyanisole (BHA) as positive control, and a blank. The anti-oxidative capacity of each sample was compared with those of BHA and the blank. Each assay was performed in triplicate and the mean standard deviation were calculated.

\subsection{THE ACETYLCHOLINESTERASE INHIBITION (ACHE INHIBITION).}

The test was qualitatively assessed using the method described by Ellman et al. (1961), as adapted for thin-layer chromatography (TLC) by Rhee et al. (2001), and was quantified using a BioTek Elisa microplate reader (model ELX 800 with Gen5 V2.04.11 software) at $405 \mathrm{~nm}$, based on the method described by Ellman et al. (1961) and modified by Trevisan et al. (2003). This in a very sensitive method based on measuring thiocholine production from hydrolysis of acetylthiocholine. This is accomplished by the continuous reaction of thiol with 5, 50-dithiobis (2-nitrobenzoic acid). The following solutions were used: A. Tris/HCl 50 mM, pH 8; B. Tris/HCl 50 mM, pH 8, with 0.1\% bovine albumin fraction $\mathrm{V}$; and $\mathrm{C}$. Tris/ $\mathrm{HCl} 50 \mathrm{mM}, \mathrm{pH}$, with $\mathrm{NaCl}$ (0.1 M) and $\mathrm{MgCl}_{2} \cdot 6 \mathrm{H}_{2} \mathrm{O}(0.02 \mathrm{M})$. To each well of a 96-well microplate, $25 \mu \mathrm{L}$ of acetylthiocholine iodide $(15 \mu \mathrm{M}), 125 \mu \mathrm{L}$ of 5,50-dithiobis in Solution C (3 $\mu \mathrm{M}$ DTNB or Ellman's reagent), $50 \mu \mathrm{L}$ of Solution B, and $25 \mu \mathrm{L}$ of compound dissolved in $\mathrm{MeOH}$ and diluted in Solution A at concentrations ranged from 1.56 to $400 \mu \mathrm{g} / \mathrm{mL}$. 


\subsection{CYTOTOXICITY AGAINST ARTEMIA SALINA}

This property was evaluated by the brine shrimp lethality test. The bioassay was modified from that described by Meyer et al. (1982) using Artemia salina Leach larvae (Crustacea, Artemiidae). Brine shrimp eggs were incubated at room temperature (between $22-29^{\circ} \mathrm{C}$ ) in artificial seawater for $48 \mathrm{~h}$. The essential oils were dissolved in methanol, DMSO, and saline water in concentrations of 10,000 to $1 \mu \mathrm{g} / \mathrm{mL}$. Then 10 shrimp larvae were added to test tubes containing $5 \mathrm{~mL}$ of each tested solution and negative and positive control solutions. Potassium dichromate $\left(\mathrm{K}_{2} \mathrm{Cr}_{2} \mathrm{O}_{7}\right)$ dissolved in saline solution and saline solution with DMSO were used as positive and negative controls, respectively. This assay was performed in triplicate and the number of dead larvae was counted after contact for $24 \mathrm{~h}$. The percentage mortality and $\mathrm{LC}_{50}$ values were evaluated through linear regression analysis.

\subsection{LARVICIDAL ASSAY AGAINST AEDES AEYPTI}

The assay was performed by the following method: L. alba essential oils were placed in beakers and dissolved in $20 \mathrm{~mL}$ of $\mathrm{H}_{2} \mathrm{O} / \mathrm{DMSO} 1.5 \%(\mathrm{v} / \mathrm{v})$ at concentrations of $50-500$ $\mathrm{mg} / \mathrm{mL}$, followed by the addition of 50 A. aegypti and A. albopictus larvae of the third instar. Mortality was recorded after $24 \mathrm{~h}$ of exposure, during which no nutritional supplement was added. The experiments were carried out at $28 \pm 2{ }^{\circ} \mathrm{C}$. Each test was performed in triplicate. Data were evaluated through regression analysis. From the regression line, the $\mathrm{LC}_{50}$ values were read, representing the concentration causing $50 \%$ larval mortality. The insecticide Temephos ${ }^{\mathrm{TM}}$ was used as positive control and a solution of water and 3\% DMSO was used as negative control (Tabanca et al., 2013; Pereira et al., 2018). The A. aegypti and A. albopictus larvae of the third instar were obtained at the Etymology Laboratory of the Vector Group of the Ceará State Health Secretariat.

\subsection{THE ANTIFUNGAL ACTIVITY}

The test was determined in accordance with guidelines of the Clinical and Laboratory Standards Institute (CLSI, 2008) by the broth microdilution method. Two strains of Trichophyton rubrum were used. Dermatophytes strains were obtained from the fungal collection of the Microbiology Laboratory, State University of Vale do Acaraú. Each strain 
was recovered and identified based on the macromorphology and micromorphology of the colonies (De Hoog et al., 2008). Aliquots of suspensions were prepared in potato dextrose agar (Difco, Detroit, MI, USA), and then incubated at $28{ }^{\circ} \mathrm{C}$ for $5-10$ days (T. rubrum strains). The suspensions were diluted to 1:500 for T. rubrum, with RPMI 1640 medium supplemented with l-glutamine without sodium bicarbonate, and then buffered to $\mathrm{pH} 7.0$ with 0.165 M MOPS. L. alba chemotypes were tested in concentrations ranging from 0.002 to $2.5 \mathrm{mg} / \mathrm{mL}$. The microdilution test was performed in 96-well microdilution plates incubated at $37^{\circ} \mathrm{C}$, and the results were expressed as minimum inhibitory concentration (MIC), while the antifungal effect was analyzed visually after 5 days (T. rubrum). The minimum fungicidal concentration (MFC) was determined by subculturing $100 \mu \mathrm{L}$ of solution from wells without turbidity on potato dextrose, at $28{ }^{\circ} \mathrm{C}$, and was determined as the lowest concentration resulting in no growth of the subculture (Fontenelle et al., 2008).

\subsection{ANTITUMOR ACTIVITY}

The cytotoxicity of the essential oils was determined by the MTT assay, following the protocol described in previous studies (Victor et al., 2017; Guedes et al., 2018). The cytotoxicity was tested against SNB-19 (astrocytoma), HCT-116 (human colon) and PC-3 (human prostate) cancer cell lines, obtained from the National Cancer Institute, Bethesda (MD, USA). Cells were cultured in RPMI-1640 medium supplemented with $10 \%$ fetal bovine serum, $1 \%$ penicillin and $1 \%$ streptomycin, and incubated at $37 \stackrel{\circ}{\circ} \mathrm{C}$ under a $5 \% \mathrm{CO}_{2}$ atmosphere. Cells were plated in 96-well plates at concentrations of $1 \mathrm{x}$ $10^{5}$ cell $\mathrm{mL}^{-1}$. After $24 \mathrm{~h}$, all fractions (50 $\left.\mu \mathrm{g} / \mathrm{mL}\right)$ dissolved in 1\% DMSO were added to each well using a high-throughput screening system (Biomek 3000 - Beckman Coulter, Inc. Fullerton, CA, USA), and the cultures were incubated for $72 \mathrm{~h}$. The fractions were centrifuged at $3000 \times \mathrm{g}$ for $10 \mathrm{~min}$ at $25 \circ \mathrm{C}$. and the supernatant removed. Then $200 \mu \mathrm{L}$ of a solution of MTT (tetrazolium salt) was added and the plates were incubated for $3 \mathrm{~h}$ at $37 \circ \mathrm{C}$. The absorbance was measured at $595 \mathrm{~nm}$ in a spectrophotometer, after dissolution of the precipitate with $150 \mu \mathrm{L}$ of DMSO. The control groups received the same amount of DMSO. The positive control used was doxorubicin at concentration of $0.3 \mathrm{mg} / \mathrm{L}$. 


\subsection{STATISTICAL ANALYSIS}

All experiments were performed in triplicate. One-way ANOVA with the Tukey test was performed followed by multiple comparison testing where appropriate. $\mathrm{IC}_{50}$ values were calculated using the GraphPad Prism 5.0 software (GraphPad Software, San Diego, CA). Significance of difference was accepted at $\mathrm{P}<0.05$.

\section{RESULTS AND DISCUSSION}

\subsection{CHARACTERIZATION OF ESSENTIAL OIL CONSTITUENTS}

The volatile oils extracted from L. alba chemotypes ranged from yellow to red, whose extraction yield were: $0.99 \%$ (LA1), 1.44\% (LA2), 0.72\% (LA3), 0.61\% (LA4), 3.31\% (LA5). $1.0 \%$ (LA6), $0.63 \%$ (LA7). The chemical composition of the essential oil chemotypes, including the retention index and the relative percentage of each constituent, are shown in Table 2. For all analyses, more than $90 \%$ of the total essential oil composition was obtained.

The chemotypes were characterized by their major constituents: camphor $(31.76 \%)$ and 1,8-cineole $(18.67 \%)$ for essential oil LA1; camphor (17.36\%) and $\beta$-caryophyllene (15.75\%) for LA2; geranial (35.60\%) and neral (23.55\%) for LA3; linalool (96.66\%) for LA4; $\beta$-caryophyllene $(26.08 \%)$ for LA5; carvone $(46.68 \%)$ and geranial $(15.65 \%)$ for LA6; and geranial (22.52\%) and $\beta$-caryophyllene (16.50\%) for LA7. 
Table 2. Comparative chemical composition (\%) of the Lippia alba essential oils obtained from different places.

\begin{tabular}{|c|c|c|c|c|c|c|c|c|}
\hline \multirow[t]{2}{*}{ Constituents } & \multirow[t]{2}{*}{$\mathrm{KI}^{\mathrm{a}}$} & \multicolumn{7}{|c|}{ Peak area (\%) } \\
\hline & & LA1 & LA2 & LA3 & LA4 & LA5 & LA6 & LA7 \\
\hline$\alpha$-Pinene & 940 & 14.41 & 17.33 & - & - & - & - & - \\
\hline Camphene & 954 & 3.07 & 2.11 & - & - & - & - & - \\
\hline$\beta$-Pinene & 979 & - & 0.96 & - & - & - & - & - \\
\hline $\begin{array}{l}\text { 6-Methyl-hepten-2- } \\
\text { one }\end{array}$ & 984 & - & - & 4.38 & - & - & 2.48 & 4.72 \\
\hline Myrcene & 988 & 0.66 & 1.02 & 6.07 & - & - & - & 2.73 \\
\hline$\alpha$-Terpinene & 1016 & 0.64 & 0.81 & - & - & - & - & - \\
\hline$p$-Cymene & 1024 & 6.48 & 13.63 & - & - & - & - & - \\
\hline$o$-Cymene & 1022 & - & - & - & - & - & 2.28 & - \\
\hline Limonene & 1026 & 3.74 & 3.92 & 7.83 & - & - & 11.94 & - \\
\hline $\begin{array}{l}\text { 1,8-Cineole } \\
\text { (eucalyptol) }\end{array}$ & 1031 & 18.67 & 15.07 & - & - & - & - & \\
\hline$\gamma$-Terpinene & 1057 & 1.73 & 0.64 & - & - & - & - & - \\
\hline Linalool & 1099 & - & - & 3.62 & 96.66 & - & 1.58 & 2.86 \\
\hline Camphor & 1146 & 31.76 & 17.36 & - & - & - & - & - \\
\hline Terpinen-4-ol & 1177 & 0.95 & 0.65 & - & - & - & - & - \\
\hline Myrtenol & 1201 & - & - & - & - & - & - & 1.14 \\
\hline Nerol & 1235 & - & - & 1.75 & - & - & - & 3.61 \\
\hline Neral & 1249 & - & - & 23.55 & - & - & 11.60 & 14.20 \\
\hline Carvone & 1252 & - & - & 3.20 & - & - & 46.68 & - \\
\hline Geraniol & 1263 & - & - & 1.74 & - & - & - & 4.10 \\
\hline Geranial & 1280 & - & - & 35.60 & - & - & 15.65 & 22.52 \\
\hline$\alpha$-Copaene & 1377 & & & & & 1.43 & & \\
\hline$\beta$-Elemene & 1381 & - & - & - & - & 10.96 & - & - \\
\hline$\beta$-Caryophyllene & 1427 & 7.70 & 15.75 & 2.47 & - & 26.08 & - & 16.50 \\
\hline Allo-aromadendrene & 1428 & 3.02 & 2.72 & - & - & - & - & - \\
\hline$\alpha$-Humulene & 1486 & - & - & - & - & 7.20 & - & - \\
\hline D-Germacrene & 1500 & - & - & - & - & 9.60 & 1.80 & 1.84 \\
\hline$\gamma$-Cadinene & 1514 & & & & & 4.38 & & \\
\hline$\delta$-Cadinene & 1523 & & & & & 9.52 & & \\
\hline
\end{tabular}


Table 2. Comparative chemical composition (\%) of the Lippia alba essential oils obtained from different places. (Continuation)

\begin{tabular}{|c|c|c|c|c|c|c|c|c|}
\hline \multirow[t]{2}{*}{ Constituents } & \multirow[t]{2}{*}{$\mathrm{KI}^{\mathrm{a}}$} & \multicolumn{7}{|c|}{ Peak area $(\%)$} \\
\hline & & LA1 & LA2 & LA3 & LA4 & LA5 & LA6 & LA7 \\
\hline$\alpha$-Cadinene & 1538 & & & & & 3.46 & & \\
\hline Elemol & 1550 & & & & & & 4.89 & \\
\hline$\beta$-Germacrene & 1562 & - & - & - & - & 6.92 & - & - \\
\hline Nerolidol & 1570 & - & - & 1.12 & - & - & - & 1.93 \\
\hline Spathulenol & 1678 & - & - & - & - & 2.92 & - & - \\
\hline Caryophyllene oxide & 1583 & 0.93 & 2.71 & 1.04 & 0.84 & 3.35 & - & 2.04 \\
\hline Globulol & 1585 & - & - & 4.73 & - & - & - & 8.67 \\
\hline Viridiflorol & 1591 & 0.64 & - & - & - & - & - & - \\
\hline Epi- $\alpha$-cadinol & 1640 & 0.93 & - & - & - & 4.28 & - & - \\
\hline$\alpha$ - Muurolol & 1646 & - & - & - & - & 0.76 & - & - \\
\hline$\alpha$-Cadinol & 1654 & - & - & - & - & 4.22 & - & 1.35 \\
\hline 2Z, 6E-Farnesol & 1694 & - & - & - & - & 0.37 & - & - \\
\hline Totarene & 1885 & - & - & - & - & - & - & 3.93 \\
\hline Total identified & & 97.41 & 94.68 & 97.10 & 100.00 & 95.45 & 98.90 & 92.14 \\
\hline
\end{tabular}

${ }^{\mathrm{a}} \mathrm{KI}$ refers to the retention index of the column Rtx-5MS and were estimated by linear regression of retention times of main compounds in the chromatograms and respective Kovats index from the literature.

Genotypes of $L$. alba have been classified as phenotypes with the different chemotypes due to variation in the concentration of their constituents and the aromatic differences, such as citral aroma. Matos et al. (1996) described six types L. alba in Brazil, with the prevalence between the clones of two chemotypes, carvone in three samples and citral (geranial + neral) and three other clones.

Environmental factors are probably the main determinants for the formation of chemotypes. Also, cytogenetic differences in the number of chromosomes in two chemotypes were found, and may be related to the speciation processes (Tavares et al., 2005). The chemotype LA4 basically presented one constituent, linalool, a monoterpene of great commercial importance in the perfume and cosmetics industry and in pharmacology due to its medicinal properties (Julião et al., 2003; Camargo and Vasconcelos, 2015). 


\subsection{ANTIOXIDANT ACTIVITY}

The inhibition of lipid peroxidation activity was determined by the $\beta$-carotene/linoleic acid system bleaching test. The results are shown in Table 3. The antioxidant activity of essential oils was concentration dependent and are expressed as IC $_{50}$ values. The chemotypes LA2, with monoterpenoids being prevalent, and LA5, with sesquiterpenoids as main constituents, had the lowest IC $_{50}$ values $(24.41 \pm 0.89 \mu \mathrm{g} / \mathrm{mL}, 29.09 \pm 0.68$ $\mu \mathrm{g} / \mathrm{mL}$, respectively). BHA (butylated hydroxyanisole) was used as standard, with antioxidant effect of $0.46 \pm 0.2 \mu \mathrm{g} / \mathrm{mL}$.

Table 3. Antioxidant activity of the Lippia alba essential oils obtained from different chemotypes.

\begin{tabular}{|c|c|}
\hline L. alba chem & $\mathrm{IC}_{50}(\mu \mathrm{g} / \mathrm{mL})$ \\
\hline LA1 & $67.16^{\mathrm{e}} \pm 2.86$ \\
\hline LA2 & $24.41^{b} \pm 0.89$ \\
\hline LA3 & $77.46^{\mathrm{f}} \pm 2.87$ \\
\hline LA4 & $52.41^{d} \pm 2.96$ \\
\hline LA5 & $29.09^{b} \pm 0.68$ \\
\hline LA6 & $43.21^{c} \pm 1.38$ \\
\hline LA7 & $71.67 \mathrm{e} \pm 1.35$ \\
\hline BHA & $0.46^{\mathrm{a}} \pm 0.2$ \\
\hline
\end{tabular}

$\mathrm{IC}_{50}$ is defined as the concentration sufficient to obtain $50 \%$ of the maximum effect of 100\%. Different letters mean significant differences between samples. ANOVA and Tukey's Multiple Comparison tests were used at $\mathrm{p}<0.05$.

In the $\beta$-carotene/linoleic acid system, the antioxidant activity can be measured since the inhibition of oxidation of linoleic acid can simulate the oxidation of the membrane lipid components (Ferreira et al., 2006). The higher antioxidant action exerted by the LA2 chemotype may be related and to the high yield of monoterpenoids like $\alpha$-pinene, 1,8-cineole and camphor. 1,8-Cineole with $\mathrm{IC}_{50}=11.01 \pm 0.41 \mu \mathrm{g} / \mathrm{mL}$ showed appreciable antioxidant activity in the DPPH test in previous study (Mogadham, 2015). The presence of methylene groups linked to double bonds in these molecules is probably the reason for this behavior (AidiWannes et al., 2010).

The L. alba essential oil chemotypes had antioxidant potential, since they contained $\alpha$ pinene, $\beta$-pinene, limonene, $p$-myrcene, 1,8-cineole and terpinen-4-ol. These monoterpenes are known to have good antioxidant properties, but depending on the 
mechanism involved in their action, some of them can exhibit low antioxidant activities (Martins et al., 2014).

The antioxidant activity found in the LA4 chemotype is due to the high concentration of linalool (96.66\%), whose antioxidant action by the $\beta$-carotene/linoleic acid system was investigated in a previous study (Hussain et al., 2008). However, an interaction between the chemical components of the essential oils can generate an antagonistic action, which might have been responsible for the moderate antioxidant action found in LA3 and LA7.

Table 4 shows the results of the AChE inhibition by qualitative (inhibition zone $-\mathrm{cm}$ ) and quantitative (inhibition $-\mu \mathrm{g} / \mathrm{mL}$ ) assays. The formation of a white halo around the TLC spots is indicative of AChE inhibition. All samples presented results close to or greater than those found for physostigmine, used as a positive control. However, the LA7 chemotype showed a stronger positive result $(1.0 \mathrm{~cm})$ than that of physostigmine in the qualitative assay.

\subsection{ACETYLCHOLINESTERASE INHIBITION ANALYSIS}

For quantitative evaluation, this inhibition was determined by the enzyme-linked immunosorbent assay (ELISA), whose the order of AChE inhibition showed that the highest action occurred in LA3 (11.49 $\pm 0.04 \mu \mathrm{g} / \mathrm{mL})$, followed by LA1 (13.20 \pm 0.88 $\mu \mathrm{g} / \mathrm{mL}$ ), which contained geranial and neral, camphor and 1,8-cineole as major constituents, respectively. Bioactive molecules that inhibit AChE have therapeutic benefits due to the ability to penetrate the blood-brain barrier, increasing the levels of endogenous acetylcholine, a useful property in therapy for Alzheimer's disease (Morais et al., 2017).

According to Jukic et al. (2007), monoterpenes like thymol, carvacrol and linalool are weak inhibitors of AChE. This may explain the weak activity found for the LA4 chemotype, which is rich in linalool. However, 1,8-cineole and limonene are monoterpenes with potent AChE inhibitory activity (Abdelgaleil et al., 2009), which may explain the activity in the LA1 chemotype. Essential oils are complex mixtures of aromatic compounds whose production depends on abiotic factors, and synergism between their constituents can modulate the inhibition of AChE. 
Table 4. Biological activities of the Lippia alba essential oils obtained from different chemotypes in brine shrimp lethality (BSLT) and acetylcholinesterase (AChE) inhibition assays (by TLC and ELISA)

\begin{tabular}{|c|c|c|c|}
\hline L. alba chemotypes & \multicolumn{1}{c}{$\begin{array}{c}\text { AChE } \\
\text { Inhibition } \\
\text { Zone }(\mathrm{cm})\end{array} \begin{array}{c}\text { AChE } \\
\text { Inhibition }(\mu \mathrm{g} / \mathrm{mL})\end{array}$} \\
\hline LA1 & $487.99^{\mathrm{c}} \pm 2.66$ & $0.8^{\mathrm{b}} \pm 0.01$ & $13.20^{\mathrm{c}} \pm 0.88$ \\
\hline LA2 & $500.83^{\mathrm{d}} \pm 0.33$ & $0.7^{\mathrm{a}} \pm 0.04$ & $35.26^{\mathrm{e}} \pm 0.71$ \\
\hline LA3 & $502.15^{\mathrm{d}} \pm 2.82$ & $0.9^{\mathrm{c}} \pm 0.02$ & $11.49^{\mathrm{b}} \pm 0.04$ \\
\hline LA4 & $494.62^{\mathrm{d}} \pm 2.11$ & $0.8^{\mathrm{b}} \pm 0.04$ & $40.50^{\mathrm{f}} \pm 0.04$ \\
\hline LA5 & $487.30^{\mathrm{c}} \pm 2.01$ & $0.7^{\mathrm{a}} \pm 0.02$ & $48.64^{\mathrm{g}} \pm 0.35$ \\
\hline LA6 & $496.74^{\mathrm{d}} \pm 2.51$ & $0.8^{\mathrm{b}} \pm 0.04$ & $49.06^{\mathrm{g}} \pm 0.13$ \\
\hline LA7 & $441.44^{\mathrm{b}} \pm 2.31$ & $1.0^{\mathrm{d}} \pm 0.02$ & $32.00^{\mathrm{d}} \pm 0.10$ \\
\hline Physostigmine & - & $0.9^{\mathrm{c}} \pm 0.04$ & $1.15^{\mathrm{a}} \pm 0,05$ \\
\hline $\begin{array}{c}\text { Potassium dichromate } \\
\left(\mathrm{K}_{2} \mathrm{Cr}_{2} \mathrm{O}_{7}\right)\end{array}$ & $11.81^{\mathrm{a}} \pm 0.04$ & - & - \\
\hline
\end{tabular}

Different letters mean significant differences between samples. ANOVA and Tukey's Multiple Comparison tests were used at $\mathrm{p}<0.05$. (-) test not performed.

\subsection{BRINE SHRIMP LETHALITY TEST (BSLT)}

The results are summarized in Table 4 and expressed as concentration required to kill $50 \%$ of the larvae ( $\mathrm{LC}_{50}$ ). According to Meyer et al. (1982), LC 50 values less than 1000 $\mu \mathrm{g} / \mathrm{mL}$ are indicative of biological activity and can be used in screening studies for natural products and proven to be a convenient system for monitoring biological activities (Krishnaraju et al., 2005). All the chemotypes presented $\mathrm{LC}_{50}$ values between 441 and $502 \mu \mathrm{g} / \mathrm{mL}$, which allows support to their many medicinal activities, indicating biotechnological potential within the diversity of chemotypes of the essential oils of the same species.

\subsection{LARVICIDAL TEST AGAINST AEDES AEGYPTI}

The larvicidal assay was carried out to determine the median lethal concentration $\left(\mathrm{LC}_{50}\right)$ against instar III larvae of Aedes aegypti and A. albopictus. The results are shown in Table 5. As positive control, Temephos ${ }^{\mathrm{Tm}}$ (0,0'-(thiodi-4,1-phenylene)bis(0,0-dimethyl phosphorothioate) was used, whose $\mathrm{LC}_{50}$ value was $1.5 \pm 0.2 \mu \mathrm{g} / \mathrm{mL}$.

Compounds with $\mathrm{LC}_{50}$ values of up to $100 \mu \mathrm{g} / \mathrm{mL}$ are considered good larvicidal agents (Cheng et al., 2003). The strongest larvicidal activities expressed by $\mathrm{LC}_{50}$ and $\mathrm{LC}_{90}$ were for the LA7 chemotype against the larval stages of $A$. aegypti. This oil is rich in neral and 
geranial and showed an $\mathrm{LC}_{50}$ value of $1.59 \pm 0.66 \mu \mathrm{g} / \mathrm{mL}$. Among essential oils with insecticidal activity against larvae of $A$. aegypti, the oil from Cymbopogon flexuosus (Nees ex Steud.) W.Watson, with citral (geranial + neral) as main component, showed the highest larvicidal activity $\left(\mathrm{LC}_{50}=17.1 \mu \mathrm{g} / \mathrm{mL}\right)$ (Vera et al., 2014). The carvone chemotype LA6 also showed good action, with $\mathrm{LC}_{50}$ of $62.98 \pm 1.08$. A previous study indicated a $\mathrm{LC}_{50}$ value of $43.8 \mu \mathrm{g} / \mathrm{mL}$ for carvone alone (Simas et al., 2004).

Table 5. Larvicidal activity of essential oils of Lippia alba obtained from different chemotypes against third-instar larvae of Aedes aegypti and Aedes albopictus after $24 \mathrm{~h}$ of exposure.

\begin{tabular}{|c|c|c|c|c|}
\hline \multirow[t]{2}{*}{$\begin{array}{c}\text { L. alba } \\
\text { chemotypes }\end{array}$} & \multicolumn{2}{|c|}{ Aedes aegypti } & \multicolumn{2}{|c|}{ Aedes albopictus } \\
\hline & $\mathrm{LC}_{50}(\mu \mathrm{g} / \mathrm{mL})$ & $\mathrm{LC}_{90}(\mu \mathrm{g} / \mathrm{mL})$ & $\mathrm{LC}_{50}(\mu \mathrm{g} / \mathrm{mL})$ & $\mathrm{LC}_{90}(\mu \mathrm{g} / \mathrm{mL})$ \\
\hline LA1 & $92.13^{c} \pm 1.18$ & $220.35^{\mathrm{d}} \pm 1.09$ & $164.2^{c} \pm 1.65$ & $446.7^{d} \pm 3.74$ \\
\hline LA2 & $190.5^{f} \pm 3.79$ & $457.32^{\mathrm{f}} \pm 3.36$ & $205.6^{d} \pm 9.55$ & $538.3^{e} \pm 39.31$ \\
\hline LA3 & $96.49 c \pm 3.82$ & $237.27 \mathrm{e} \pm 4.84$ & - & - \\
\hline LA4 & $148.56^{\mathrm{e}} \pm 3.32$ & $503.50^{g} \pm 5.66$ & $450.6^{f} \pm 2,0$ & $3043.6^{g} \pm 6.09$ \\
\hline LA5 & $113.99^{\mathrm{d}} \pm 1.31$ & $210.92^{\mathrm{d}} \pm 6.05$ & $275.1^{\mathrm{e}} \pm 6.95$ & $1100.0^{f} \pm 5.14$ \\
\hline LA6 & $62.98^{\mathrm{b}} \pm 1.08$ & $158.18 \mathrm{c} \pm 2.63$ & $113.4^{b} \pm 0.92$ & $286.8^{\mathrm{b}} \pm 0.19$ \\
\hline LA7 & $1.59 \mathrm{a} \pm 0.66$ & $74.73^{\mathrm{b}} \pm 1.23$ & $169.2^{c} \pm 1.0$ & $396.2^{c} \pm 3.64$ \\
\hline Temephos $^{\mathrm{TM}}$ & $1.5^{\mathrm{a}} \pm 0.2$ & $3.27^{a} \pm 0.17$ & $0.01^{\mathrm{a}} \pm 0.20$ & $1.78^{a} \pm 0.10$ \\
\hline
\end{tabular}

Different letters mean significant differences between samples. ANOVA and Tukey's Multiple Comparison tests were used at $\mathrm{p}<0.05$. (-) test not performed.

LA7 showed the best larvicidal action against A. aegypti of all investigated L. alba chemotypes, with $\mathrm{LC}_{50}$ value of $1.59 \pm 0.66 \mu \mathrm{g} / \mathrm{mL}$, a result very close to that of Temephos $^{\mathrm{TM}}$ (positive control). This action is due to the synergism of its major constituents geranial, $\beta$-caryophyllene and neral. A previous study of Cymbopogon citratus (DC.) Stapf essential oil, whose main chemical constituents were geranial (60.3\%) and neral (39.7\%), showed larvicidal action with $\mathrm{LC}_{50}$ value of $69 \mu \mathrm{g} / \mathrm{mL}$ against $A$. aegypti (Cavalcanti et al., 2004).

The larvicidal action described for LA7 can be related to the AChE inhibitory activity, due to the presence of many larvicidal substances that inhibit the action of acetylcholinesterase, by inhibiting the hydrolysis of the neurotransmitter acetylcholine into acetate and choline (Colovic et al., 2013). 


\subsection{ANTIFUNGAL ASSAY}

The activity against pathogenic fungal strains, shown in Table 6, the chemotypes LA1, LA2, LA3 and LA6 showed the highest antifungal activity against T. rubrum strains compared to the other chemotypes. These antifungal essential oils contain mainly monoterpenoids, such as $\alpha$-pinene, camphor, 1,8-cineole, neral and geranial. A previous study identified antifungal activity against yeasts and filamentous fungi of the citral and carvone chemotypes of L. alba (Mesa-Arango et al., 2009). The chemical composition of a commercial sample of essential oil from Eucalyptus smithii R.T. containing 1,8-cineole as the main constituent was reported to be active against several strains of Microsporum and Trichophyton (Boulatari et al., 2015). Our data corroborate the previous findings of the better antifungal action of oils containing these constituents.

Table 6. Minimum inhibitory concentration of the Lippia alba essential oils obtained from different chemotypes against T. rubrum

\begin{tabular}{c|c|c|c|c|c|c|c|c|}
\multirow{2}{*}{ Strains } & \multicolumn{2}{c|}{ MIC/MFC } & \multicolumn{2}{c|}{$(\mathrm{mg} / \mathrm{ml})$} & \\
\cline { 2 - 8 } & LA1 & LA2 & LA3 & LA4 & LA5 & LA6 & LA7 & KTC \\
$\begin{array}{c}\text { T. rubrum } \\
\text { LABMIC 0208 }\end{array}$ & $0.62 / 1.25$ & $1.25 / 2.5$ & $0.62 / 1.25$ & $1.25 / 2.5$ & NI & $0.62 / 1.25$ & $1.25 / 2.5$ & 0.25 \\
\hline $\begin{array}{c}\text { T. rubrum } \\
\text { LABMIC 0209 }\end{array}$ & $0.62 / 1.25$ & $0.15 / 0.31$ & $0.62 / 1.25$ & $1.25 / 2.5$ & NI & $0.62 / 1.25$ & $1.25 / 2.5$ & 0.25 \\
\hline $\begin{array}{c}\text { Geometric } \\
\text { mean }\end{array}$ & $0.62 / 1.25$ & $0.43 / 0.88$ & $0.62 / 1.25$ & $1.25 / 2.5$ & NI & $0.62 / 1.25$ & $1.25 / 2.5$ & 0.25 \\
\hline
\end{tabular}

NI: no inhibition; KTC: ketoconazole; MIC: minimum inhibitory concentration; MFC: minimum fungicidal concentration.

\subsection{CYTOTOXICITY ACTIVITY}

The cytotoxicity was determined by the MTT assay, which is a well-established colorimetric assay based on the enzymatic reduction of the tetrazolium salt MTT in living, metabolically active cells, but not in dead cells (Macêdo et al., 2018). The inhibition percentage of cell growth was high (75-100\%) to moderate (51-74\%) (ISO 10993-5:, 2009). All the chemotypes showed high cytotoxic activity against the cancer cell lines used in this study, except LA5, whose inhibition percentage ranged from 31.7073.94 (Table 7). 
Table 7. Cell proliferation inhibition (\%) of the Lippia alba essential oils obtained from different chemotypes determined by MTT assay at the concentration of $50 \mathrm{mg} / \mathrm{mL}$.

\begin{tabular}{|c|c|c|c|c|}
\hline \multirow[t]{2}{*}{ Chemotype } & \multicolumn{3}{|c|}{ Cell proliferation inhibition (\%) } & $I C_{50}(\mu \mathrm{g} / \mathrm{mL})$ \\
\hline & НСТ-116 & PC-3 & SNB-19 & НСТ-116 \\
\hline LA1 & $89.69^{c} \pm 1.01$ & $82.41^{c} \pm 1.37$ & $79.50^{c} \pm 1.11$ & 24.89 \\
\hline LA2 & $91.02^{c} \pm 0.32$ & $84.20^{c} \pm 1.26$ & $64.90^{\mathrm{d}} \pm 1.20$ & 33.81 \\
\hline LA3 & $95.28^{b} \pm 0.64$ & $97.37 \mathrm{a} \pm 0.97$ & $89.83^{b} \pm 0.72$ & 5.49 \\
\hline LA4 & $88.41^{\mathrm{c}} \pm 1.08$ & $82.27^{c} \pm 1.49$ & $49.44^{e} \pm 1.59$ & 42.76 \\
\hline LA5 & $73.94^{\mathrm{d}} \pm 1.18$ & $47.83^{\mathrm{d}} \pm 1.99$ & $31.70^{f} \pm 1.11$ & $>100$ \\
\hline LA6 & $93.15^{b} \pm 0.93$ & $87.80^{\mathrm{b}} \pm 1.21$ & $87.41^{b} \pm 0.11$ & $>100$ \\
\hline LA7 & $93.07^{b} \pm 1.80$ & $91.02^{b} \pm 1.43$ & $89.23^{b} \pm 1.48$ & 9.22 \\
\hline Doxorubicin & $99.99 a \pm 0.01$ & $99.99 a \pm 0.01$ & $99.99 a \pm 0.01$ & 0.21 \\
\hline
\end{tabular}

Different letters mean significant differences between samples. ANOVA and Tukey's Multiple Comparison tests were used at $\mathrm{p}<0.05$. (-) test not performed.

Previous studies have determined the cytotoxic potential of $L$. alba essential oil, rich in geraniol (18.9\%) and citral (15.9\%), against CHO-Chinese hamster ovary cells (TofiñoRivera et al., 2016) and K562-leukemia cells (García et al., 2017). These results are in line with those of present study, according to which L. alba demonstrated good antiproliferative effect (Fig. 1), due to the content of oxygenated monoterpenoids in the oils. There also may be a synergistic effect, by modifying the response to the various investigated chemotypes.

Figure 1. Cell proliferation inhibition (\%) of the Lippia alba essential oils obtained from different chemotypes.

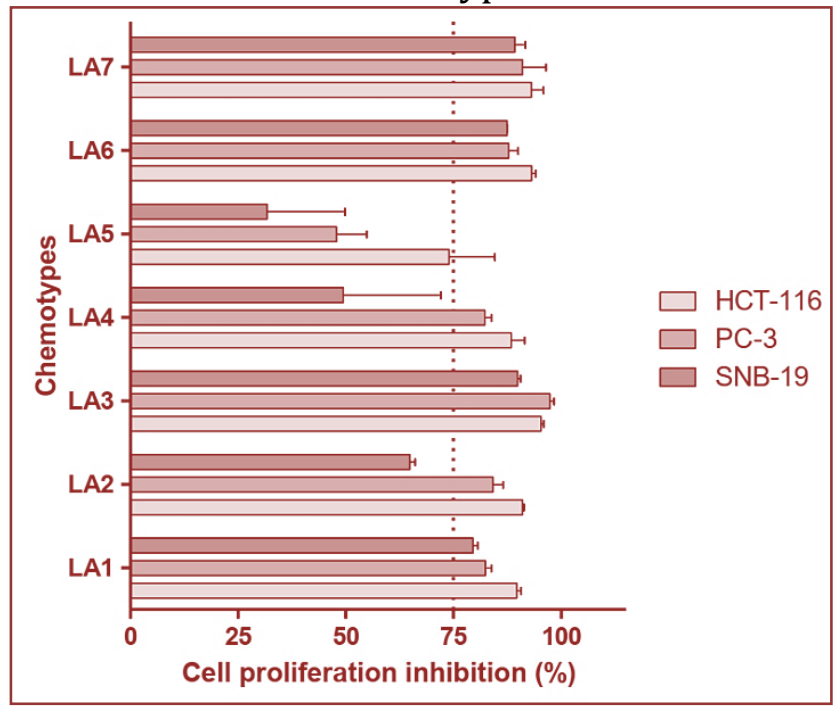


Among all the cancer cell lines tested, HCT-116 presented the highest cell proliferation inhibitory effect at the concentration of $50 \mu \mathrm{g} / \mathrm{mL}$ in all the tested chemotypes. Thus, the $\mathrm{IC}_{50}$ was determined, whose values ranged from 5.49-42.76 $\mu \mathrm{g} / \mathrm{mL}$ (Table 7). The LA5 and LA6 chemotypes only had weak antiproliferative action, with IC $_{50}$ of more than 100 $\mu \mathrm{g} / \mathrm{mL}$. However, the LA3 and LA7 chemotypes were able to reduce cell viability of HCT116 in low concentrations, approaching the results obtained for the standard drug, doxorubicin.

$\beta$-caryophyllene and $\beta$-caryophyllene oxide are present in a large number of plants worldwide. Both compounds possess significant anticancer activities, affecting growth and proliferation of numerous cancer cell lines (Fidyt et al., 2016). The aldehydes geranial and neral demonstrated cytotoxic and antitumor effect against the HeLa cell line (Mesa-Arango et al., 2009). Citral (geranial + neral) and $\beta$-caryophyllene was major constituents found in some chemotypes, like LA3 and LA7, which could explain their better anticancer activity.

\section{CONCLUSIONS}

The chemical diversity allowed the identification of different chemotypes, whose medicinal properties were investigated, revealing a biotechnological potential of this plant. The results presented here indicate the main constituents of each chemotype, as well as the biological activities, which include antioxidant, antiacetylcholinesterase, antifungal and larvicidal activities, along with cytotoxicity against cancer cells. The chemical composition of the essential oils undergoes changes due to environmental factors and the circadian cycle. In addition, major constituents may influence on the biological action, then there is a need to study the constituents separately through in vivo assays. 


\section{REFERENCES}

Abdelgaleil, S. A. M.; Mohamed, M. I. E.; Badawy, M.E.I.; El-arami, S.A.A. Fumigant and contact toxicities of monoterpenes to Sitophilus oryzae (L.) and Tribolium castaneum (Herbst) and their inhibitory effects on acetylcholinesterase activity Journal of Chemical Ecology, v. 35, n. 5, p. 518-525, 2009.

Adams, R. P. Identification of Essential Oil Components by Gas Chromatography/Mass Spectrometry. Allured Publishing Corporation, Illinois. 2012.

AidiWannes, W.; Mhamdi, B.; Sriti, J.; Ben Jemia, M.; Ouchikh, O.; Hamdaoui, G.; Kchouk, M. E.; Marzouk, B. Antioxidant activities of the essential oils and methanol extracts from myrtle (Myrtuscommunis var. italica L.) leaf, stem and flower. Food and chemical toxicology, v. 48, n. 5, p. 1362-1370, 2010.

Albuquerque, U. P.; Medeiros, P. M.; Almeida, A. L. S.; Monteiro, J. M.; Neto, E. M. F. L.; Melo, J. G.; Santos, J. P. Medicinal plants of the caatinga (semi-arid) vegetation of NE Brazil: a quantitative approach. Journal of Ethnopharmacology, v. 114, n. 3, p. 325-354, 2007.

Ali-Shtayeh, M. S., Jamous, R. M., Abu-Zaitoun, S. Y., Akkawi, R. J., Kalbouneh, S. R., Dudai, N., Bernstein, N. Secondary treated effluent irrigation did not impact chemical composition, and enzyme inhibition activities of essential oils from Origanum syriacum var. syriacum. Industrial Crops and Products, v. 111, p. 775-786, 2018.

Andrade, M. A.; Cardoso, M. D. G.; Batista, L. R.; Mallet, A. C. T.; Machado, S. M. F. Óleos essenciais de Cymbopogon nardus, Cinnamomum zeylanicum e Zingiber officinale: composição, atividades antioxidante e antibacteriana. Revista Ciência Agronômica, v. 43, n. 2, p. 399-408, 2012.

Camargo, S. B.; Vasconcelos, D. F. S. A. Atividades biológicas de Linalol: conceitos atuais e possibilidades futuras deste monoterpeno. Revista de Ciências Médicas e Biológicas, v. 13, n. 3, p. 381-387, 2014.

Cardoso, J. L. M. S., Soares, M. J. S., Leite, J. R. S. A., Malaquias, L. C. C., Coelho, L. F. L. Antiviral activity of dermaseptin 01 against Dengue virus type 2, Herpes simplex virus type 1 and Vaccinia virus. Scientia Medica, v. 23, n. 1, p. 3, 2013.

Cavalcanti, E. S. B.; Morais, S. M. D.; Lima, M. A. A.; Santana, E. W. P. Larvicidal activity of essential oils from Brazilian plants against Aedes aegypti L. Memórias do Instituto Oswaldo Cruz, v. 99, n. 5, p. 541-544, 2004.

Cheng, S. S.; Chang, H. T.; Chang, S. T.; Tsai, K. H.; Chen, W. J. Bioactivity of selected plant essential oils against the yellow fever mosquito Aedes aegypti larvae. Bioresource Technology, v. 89, n. 1, p. 99-102, 2003.

Clinical and Laboratory Standards Institute. Reference Method for Broth Dilution Antifungal Susceptibility Testing of Filamentous Fungi (Approved Standard. Document M38. CLSI). Second ed.vol. M38-A2. Clinical and Laboratory Standards Institute, Wayne, PA, 2008.

Colovic, M. B.; Krstic, D. Z.; Lazarevic-Pasti, T. D.; Bondzic, A. M.; Vasic, V. M. Acetylcholinesterase inhibitors: pharmacology and toxicology. Current Neuropharmacology, v. 11, n. 3, p. 315-335, 2013.

Craveiro, A. A.; Matos, F. J. A.; Alencar, J. W. A simple and inexpensive steam generator for essential oils extraction. Journal of Chemical Education, v. 53, n. 10, p. 652, 1976.

De Hoog, G. S.; Guarro, J.; Gené, J.; Figueras, M. J. Atlas of Clinical Fungi, 4th edn. Utrecht, The Netherlands: Centralalbureau voor Schimmelcultures/Universitat Rovira I Virgili Reus, 2008.

Ellman GL, Courtney KD, Andres Jr V, Featherstone RM (1961) A new and rapid colorimetric determination of acetylcholinesterase activity. Biochemical Pharmacology, v. 7, n. 2, p. 88-95, 1961.

Escobar, P.; Leal, S. M.; Herrera, L. V.; Martinez, J. R.; Stashenko, E. Chemical composition and antiprotozoal activities of Colombian Lippia spp essential oils and their major components. Memórias do Instituto Oswaldo Cruz, v. 105, n. 2, p. 184-190, 2010.

Ferreira, A.; Proença, C.; Serralheiro, M. L. M.; Araujo, M. E. M. The in vitro screening for acetylcholinesterase inhibition and antioxidant activity of medicinal plants from Portugal. Journal of Ethnopharmacology, v. 108, n. 1, p. 31-37, 2006.

Fontenelle, R. O. S.; Morais, S. M.; Brito, E. H. S.; Brilhante, R. S. N.; Cordeiro, R. A.; Nascimento, N. R. F.; Kerntopf, M. R.; Sidrim, J. J. C.; Rocha, M. F. G. Antifungal activity of essential oils of Croton species from the Brazilian Caatinga biome. Journal of Applied Microbiology, v. 104, n. 5, p. 1383-1390, 2008. 
Gade, S.; Rajamanikyam, M.; Vadlapudi, V.; Nukala, K. M.; Aluvala, R.; Giddigari, C.; Karanam, N. J.; Barua, N. C.; Pandey, R.; Upadhyayula, V. S. V.; Sripadi, P.; Amanchy, R.; Upadhyayula, S. M. Acetylcholinesterase inhibitory activity of stigmasterol \& hexacosanol is responsible for larvicidal and repellent properties of Chromolaena odorata. Biochimica et Biophysica Acta (BBA)-General Subjects, v. 1861, n. 3, p. 541-550, 2017.

García, L. T.; Leal, A. F.; Moreno, É. M.; Stashenko, E. E.; Arteaga, H. J. Differential anti-proliferative effect on K562 leukemia cells of Lippia alba (Verbenaceae) essential oils produced under diverse growing, collection and extraction conditions. Industrial Crops and Products, v. 96, p. 140-148, 2017.

Guedes, J. A. C.; Filho, E. G. A.; Rodrigues, T. H. S.; Silva, M. F. S.; Souza, F. V. D.; Silva, L. M. A.; Alves, R. E.; Canuto, K. M.; Brito, E. S.; Pessoa, C. Ó.; Nascimento, R. F.; Zocolo, G, J. Metabolic profile and cytotoxicity of non-polar extracts of pineapple leaves and chemometric analysis of different pineapple cultivars. Industrial Crops and Products, v. 124, p. 466-474, 2018.

Harvey, A. L.; Edrada-Ebel, R.; Quinn, R. J. The re-emergence of natural products for drug discovery in the genomics era. Nature Reviews Drug Discovery, v. 14, n. 2, p. 111-129, 2015.

Hennebelle, T.; Sahpaz, S.; Joseph, H.; Bailleul, F. Ethnopharmacology of Lippia alba. Journal of Ethnopharmacology, v. 116, n. 2, p. 211-222, 2008.

Hussain, A. I.; Anwar, F.; Sherazi, S. T. H.; Przybylski, R. Chemical composition, antioxidant and antimicrobial activities of basil (Ocimum basilicum) essential oils depends on seasonal variations. Food chemistry, v. 108, n. 3, p. 986-995, 2008.

ISO 10993-5, 2009 ISO 10993-5. Biological Evaluation of Medical Devices - part 5: Tests for In Vitro Cytotoxicity International Organization for Standardization, Geneva, 2009.

Jukic, M.; Politeo, O.; Maksimovic, M.; Milos, M.; Milos, M. In Vitro acetylcholinesterase inhibitory properties of thymol, carvacrol and their derivatives thymoquinone and thymohydroquinone. Phytotherapy Research, v. 21, n. 3, p. 259-261, 2007.

Julião, L. S.; Tavares, E. S.; Lage, C. L. S.; Leitão, S. G. Cromatografia em camada fina de extratos de três quimiotipos de Lippia alba (Mill) NE Br.(erva-cidreira). Revista Brasileira de Farmacognosia, v. 13, p. 3638, 2003.

Krishnaraju, A. V.; Rao, T. V.; Sundararaju, D.; Vanisree, M.; Tsay, H. S.; Subbaraju, G. V. Assessment of bioactivity of Indian medicinal plants using brine shrimp (Artemia salina) lethality assay. Int J Appl Sci Eng, v. 3, n. 2, p. 125-34, 2005.

Londono-Renteria, B.; Troupin, A.; Colpitts, T. M. Arbovirosis and potential transmission blocking vaccines. Parasites \& Vectors, v. 9, n. 1, p. 516, 2016.

Lopes-Lutz, D.; Alviano, D. S.; Alviano, C. S.; Kolodziejczyk, P. P. Screening of chemical composition, antimicrobial and antioxidant activities of Artemisia essential oils. Phytochemistry, v. 69, n. 8, p. 17321738, 2008.

López, M. A.; Stashenko, E. E.; Fuentes, J. L. Chemical composition and antigenotoxic properties of Lippia alba essential oils. Genetics and Molecular Biology, v. 34, n. 3, p. 479-488, 2011.

Matos, F. J. A. (1996) As ervas cidreiras do Nordeste do Brasil. Estudo de três quimiotipos de Lippia alba (Mill.) N. E. Brown (Verbenaceae) Parte II - Farmacoquímica. Revista Brasileira de Farmacognosia, v. 77, p. 137-141, 1996.

Martins, M. D. R.; Arantes, S.; Candeias, F.; Tinoco, M. T.; Cruz-Morais, J. Antioxidant, antimicrobial and toxicological properties of Schinusmolle L. essential oils. Journal of Ethnopharmacology, v. 151, n. 1, p. 485492, 2014.

Mesa-Arango, A. C.; Montiel-Ramos, J.; Zapata, B.; Durán, C.; Betancur-Galvis, L.; Stashenko, E. Citral and carvone chemotypes from the essential oils of Colombian Lippia alba (Mill.) NE Brown: composition, cytotoxicity and antifungal activity. Memorias do Instituto Oswaldo Cruz, v. 104, n. 6, p. 878-884, 2009.

Mesquita, B. M. D.; Nascimento, P. G.; Souza, L. G.; Farias, I. F. D.; Silva, R. A.; Lemos, T. L.; Monte, F. J. Q.; Oliveira, I. R.; Trevisan, M. T. S.; Silva, H. C.; Santiago, G. M. P. Synthesis, larvicidal and acetylcholinesterase inhibitory activities of carvacrol/thymol and derivatives. Quimica Nova, v. 41, n. 4, p. 412-416, 2018.

Meyer, B. N.; Ferrigni, N. R.; Putnam, J. E.; Jacobsen, L. B.; Nichols, D. J.; McLaughlin, J. L. Brine shrimp: a convenient general bioassay for active plant constituents. Planta Medica, v. 45, n. 05, p. 31-34, 1982. 
Moghadam, A. R. L. (2015) Antioxidant activity and chemical composition of Rosmarinus officinalis L. essential oil from Iran. Journal of Essential Oil Bearing Plants, v. 18, n. 6, p. 1490-1494, 2015.

Morais, S. M.; Silva, K. A.; Araujo, H.; Vieira, I. G.; Alves, D. R.; Fontenelle, R. O. S.; Silva, A. M. S. Anacardic acid constituents from cashew nut shell liquid: NMR characterization and the effect of unsaturation on its biological activities. Pharmaceuticals, v. 10, n. 1, p. 31, 2017.

Ocazionez, R. E.; Meneses, R.; Torres, F. Á.; Stashenko, E. Virucidal activity of Colombian Lippia essential oils on dengue virus replication in vitro. Memórias do Instituto Oswaldo Cruz, v. 105, n. 3, p. 304-309, 2010.

Porfírio, E. M.; Melo, H. M.; Pereira, A. M. G.; Cavalcante, T. T. A.; Gomes, G. A.; Carvalho, M. G. D.; Costa, R. A.; Júnior, F. E. A. C. In vitro antibacterial and antibiofilm activity of Lippia alba essential oil, citral, and carvone against Staphylococcus aureus. The Scientific World Journal, v. 2017, 2017.

Pereira, E. J. P.; Silva, H. C.; Holanda, C. L.; Menezes, J. E. S. A.; Siqueira, S. M. C.; Rodrigues, T. H. S.; Fontenelle, R. O. S., Vale, J. P. C.; Silva, P. T.; Santiago, G. M. P.; Santos, H. S. Chemical composition, cytotoxicity and larvicidal activity against Aedes aegypti of essential oils from Vitex gardineriana Schauer. Boletín Latinoamericano y del Caribe de Plantas Medicinales y Aromáticas, v. 17, p. 302-308, 2018.

Raj, G. A.; Chandrasekaran, M.; Krishnamoorthy, S.; Jayaraman, M.; Venkatesalu, V. Phytochemical profile and larvicidal properties of seed essential oil from Nigella sativa L. (Ranunculaceae), against Aedes aegypti, Anopheles stephensi, and Culex quinquefasciatus (Diptera: Culicidae). Parasitology Research, v. 114, n. 9, p. 3385-3391, 2015.

Rhee, I. K.; van de Meent, M.; Ingkaninan, K.; Verpoorte, R. Screening for acetylcholinesterase inhibitors from Amaryllidaceae using silica gel thin-layer chromatography in combination with bioactivity staining. Journal of Chromatography A, v. 915, n. 1-2, p. 217-223, 2001.

Salimena, F. R. G.; Ferreira, S. C.; Cardoso, P. H.; Valério, V. I. R. Verbenaceae. In: Rizzo, J A. (ed.) Flora dos estados de Goiás e Tocantins. Coleção Rizzo. Vol. 47. Universidade Federal de Goiás, Goiânia. pp. 1-157, 2016.

Silva, R. E. R.; Morais, L. P.; Silva, A. A.; Bastos, C. M. S.; Pereira-Gonçalves, Á.; Kerntopf, M. R.; Menezes, I. R. A.; Leal-Cardoso, J. H.; Barbosa, R. Vasorelaxant effect of the Lippia alba essential oil and its major constituent, citral, on the contractility of isolated rat aorta. Biomedicine \& Pharmacotherapy, v. 108, p. 792-798, 2018.

Simas, N. K.; Lima, E. D. C.; Conceicao, S. D. R.; Kuster, R. M.; Oliveira Filho, A. D.; Lage, C. L. S. Produtos naturais para o controle da transmissão da dengue-atividade larvicida de Myroxylon balsamum (óleo vermelho) e de terpenóides e fenilpropanóides. Química Nova, v. 27, n. 1, p. 46-49, 2004.

Stashenko, E. E.; Jaramillo, B. E.; Martínez, J. R. Comparison of different extraction methods for the analysis of volatile secondary metabolites of Lippia alba (Mill.) NE Brown, grown in Colombia, and evaluation of its in vitro antioxidant activity. Journal of Chromatography A, v. 1025, n. 1, p. 93-103, 2004.

Suárez, M. E. Medicines in the forest: Ethnobotany of wild medicinal plants in the pharmacopeia of the Wichí people of Salta province (Argentina). Journal of Ethnopharmacology, v. 231, p. 525-544, 2019.

Tabanca, N.; Avonto, C.; Wang, M.; Parcher, J. F.; Ali, A.; Demirci, B.; Raman, V.; Khan, I. A. Comparative investigation of Umbellularia californica and Laurus nobilis leaf essential oils and identification of constituents active against Aedes aegypti. Journal of Agricultural and Food Chemistry, v. 61, n. 50, p. 12283-12291, 2013.

Tavares, E. S.; Lopes, D.; Bizzo, H. R.; Lage, C. L. S.; Leitão, S. G. Kinetin enhanced linalool production by in vitro plantlets of Lippia alba. Journal of Essential Oil Research, v. 16, n. 5, p. 405-408, 2004.

Tavares, E. S.; Julião, L. S.; Lopes, D.; Bizzo, H. R.; Lage, C. L. S.; Leitão, S. G. Analysis of the essential oil from leaves of three Lippia alba (Mill.) NE Br. (Verbenaceae) chemotypes cultivated on the same conditions. Revista Brasileira de Farmacognnosia, v. 15, p. 1-5, 2005.

Tofiño-Rivera, A.; Ortega-Cuadros, M.; Galvis-Pareja, D.; Jiménez-Rios, H.; Merini, L. J.; Martínez-Pabón, M. C. Effect of Lippia alba and Cymbopogon citratus essential oils on biofilms of Streptococcus mutans and cytotoxicity in CHO cells. Journal of Ethnopharmacology, v. 194, p. 749-754, 2016. 
Trevisan, M. T. S.; Macedo, F. V. V.; van de Meent, M.; Rhee, I. K.; Verpoorte, R. Seleção de plantas com atividade anticolinasterase para tratamento da doença de Alzheimer. Química Nova, v. 26, n. 3, p. 301-304, 2003.

Vera, S. S.; Zambrano, D. F.; Méndez-Sanchez, S. C.; Rodríguez-Sanabria, F.; Stashenko, E. E.; Luna, J. E. D. Essential oils with insecticidal activity against larvae of Aedes aegypti (Diptera: Culicidae). Parasitology Research, v. 113, n. 7, p. 2647-2654, 2014.

Victor, M. M.; David, J. M.; Santos, M. A.; Barreiros, A. L.; Barreiros, M. L.; Andrade, F. S.; Carvalho, A. A.; Luciano, M. C. S.; Moraes, M. O.; Baros-Nepomuceno, F. W. A.; Pessoa, C. Synthesis and Evaluation of Cytotoxic Effects of Amino-ester Derivatives of Natural $\alpha, \beta$-Amyrin Mixture. Journal of the Brazilian Chemical Society, v. 28, n. 11, p. 2155-2162, 2017.

Yamamoto, P. Y.; Colombo, C. A.; Azevedo Filho, J. A.; Lourenção, A. L.; Marques, M. O. M.; Morais, G. D. D. S.; Chiorato, A. F.; Martins, A. L. M.; Siqueira, W. J. Performance of ginger grass (Lippia alba) for traits related to the production of essential oil. Scientia Agricola, v. 65, n. 5, p. 481-489, 2008. 


\section{Chapter 2}

Essential oils from Curcuma longa and Curcuma zedoaria grown in Brazil as larvicides against Aedes aegypti $L$.

Celma de Oliveira Barbosa

Selene Maia de Morais

Vitor Carvalho Martins

João Francisco Câmara Neto

Icaro Gusmão Pinto Vieira

Rita de Cássia Alves Pereira and José Osvaldo Beserra Carioca

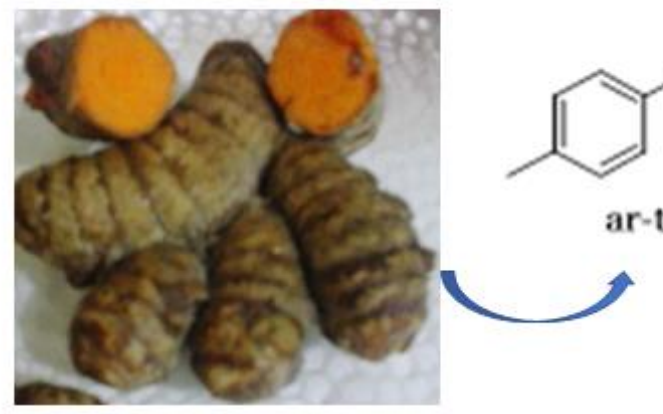

Curcuma longa

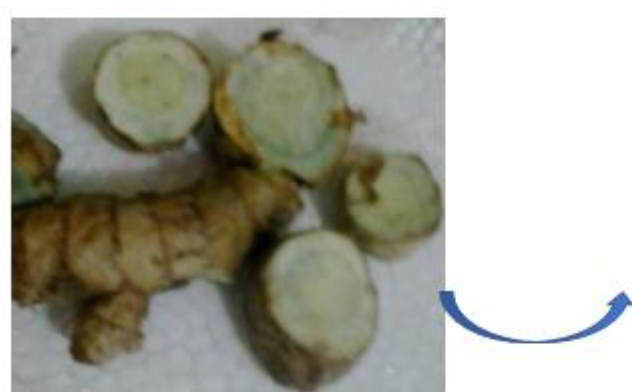

Curcuma zeodaria

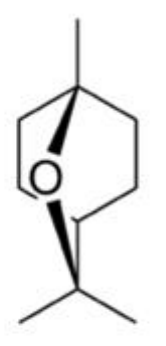

1,8-cineol<smiles>CC(C)=CC(=O)CC(C)C1C=CC(C)=CC1</smiles>

$\alpha$-turmerone<smiles>C=C1C=CC(C(C)CC(=O)C=C(C)C)CC1</smiles>
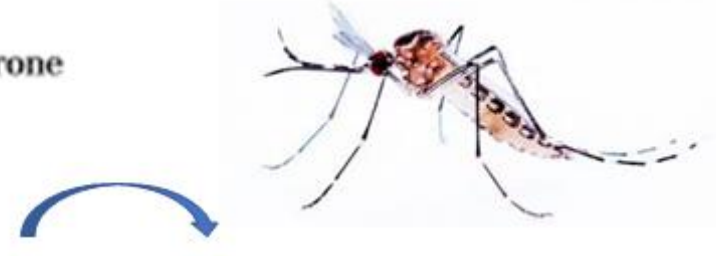

B-turmerone

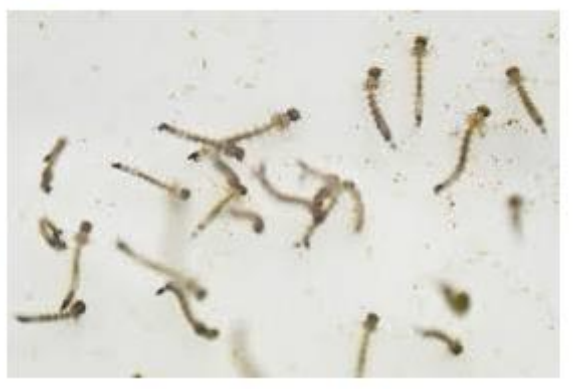

Larvicidal activity against Aedes aegypti 


\section{INTRODUCTION}

Aedes aegypti Linnaeus is a mosquito species that plays an important role as a vector of diseases in tropical and subtropical zones. Aedes aegypti (L.) is the main vector of Dengue Hemorrhagic Fever (DHF) and Zika (Sutiningsih et al. 2017), and Chikungunya. To control mosquitoes and arbovirais diseases, which have a worldwide health and economic impacts, synthetic insecticide-based interventions are still necessary, particularly in situations of epidemic outbreak and sudden increases of adult mosquitoes (Nathan et al. 2006). However, the indiscriminate use of conventional insecticides is fostering problems like widespread development of insecticide resistance, toxic hazards to mammals, undesirable effects on nontarget organisms, and environmental pollution (Sutthanont et al. 2010). It is important to develop vector control methods that are more environmentally friendly and less costly, as larvicide deriving from plants.

Essential oils are potentially used in larval control management because they constitute a rich source of bioactive compounds that are effective and naturally biodegradable into non-toxic products (Sutthanont et al. 2010). A large number of plants, including Zingiberaceae, Rutaceae, Euphorbiaceae and Myrtaceae family, shows essential oils with larvicidal activity (Sutthanont et al. 2010; Morais et al. 2006). Popularly known as zedoaria, the Curcuma zedoaria (Christm.) Roscoe is an Indian plant of the family Zingiberaceae (Shinobu-Mesquita et al. 2011) and is a close relative of Curcuma longa (Zingiberaceae) (Widyowati and Agil 2018). Curcuma longa, known as turmeric, is native from south and southeast Asia (Ali et al. 2015).

In medicine, turmeric is extensively used for the management of various diseases, related to antioxidant, anti-inflammatory and cancer preventive properties due to curcuminoids (Dall'Acqua et al. 2016). The rhizomes of $C$. longa have also been reported with varied biological activities, including the toxicity against Aedes aegypti and Anopheles quadrimaculatus of hexane extracts and constituents (Roth et al. 1998, Ali et al. 2015). Curcuma zedoaria (white turmeric), Boesenbergia rotunda and Hedychium coronarium essential oils tested resulted in 100\% mortality against Ae. aegypti and Cx. quin-quefasciatus larvae at 60 minutes and 30 minutes, respectively (Phukerd and Soonwera 2013). 
The increase in resistance of the Aedes aegypti larvae and the slow delivery of new therapeutic strategies to Dengue, Zika and Chikungunya combat, increase researchers' interest in locally grown plants with use in traditional medicine. Thus, the present study investigated the chemical composition and larvicidal activity of Curcuma longa and Curcuma zedoaria essential oils against Aedes aegypti larvae.

\section{MATERIALS AND METHODS}

\subsection{PLANT MATERIAL AND ESSENTIAL OIL EXTRACTION}

C. longa and C. zedoaria were cultivated and collected during the morning at garden of Embrapa Tropical Agroindustry (Ceará), located at the Federal University of Ceará (Ceará). The taxonomic identification was perfomed in the Department of Biology, Prisco Bezerra Herbarium, Federal University of Ceará, voucher 59673 to Curcuma longa and 60403 to Curcuma zedoaria. The essential oils were extracted from plants in the Natural Plants Products Laboratory, at Ceara State University by hydrodistillation as described in the literature by A.O.A.C (1995).

\subsection{GENERAL EXPERIMENTAL PROCEDURES}

\subsubsection{THE ESSENTIAL OILS WERE SUBMITTED TO ANALYSIS BY CG/MS AND RMN.}

The CG/MS analysis was performed with a Shimadzu QP-2010 instrument using the following conditions: column: DB-1 MS (Agilent, part No. 122-5532) coated fused silica capillary column $(30 \mathrm{~m} \times 0.25 \mathrm{~mm} \times 0.25 \mu \mathrm{m})$; carrier gas: He $(1 \mathrm{~mL} / \mathrm{min}$, in constant linear velocity mode); the injector temperature was $250^{\circ} \mathrm{C}$, in split mode, and the detector temperature was $250^{\circ} \mathrm{C}$. The column temperature was programmed from $35-$ $180^{\circ} \mathrm{C}$ at $4^{\circ} \mathrm{C} / \mathrm{min}$ then $180-280^{\circ} \mathrm{C}$ at $17^{\circ} \mathrm{C} / \mathrm{min}$, and at $280^{\circ} \mathrm{C}$ for $10 \mathrm{~min}$; mass spectra: electron impact $70 \mathrm{eV}$. The sample was injected in volume of $1 \mu \mathrm{L}$. Compounds were identified by their retention times relative in GC to known compounds and by comparison of their mass spectra with those present in the computer data bank (NIST) and published literature (Adams 2007).

The ${ }^{1} \mathrm{H}$ and ${ }^{13} \mathrm{C}$ NMR were obtained on Bruker spectrometers, Avance DRX-500 (500 $\mathrm{MHz}$ for ${ }^{1} \mathrm{H}$ and $125 \mathrm{MHz}$ for ${ }^{13} \mathrm{C}$ ) or DPX-300 (300 MHz for ${ }^{1} \mathrm{H}$ and $75 \mathrm{MHz}$ for ${ }^{13} \mathrm{C}$ ), 
proton chemical shifts were referenced to the residual undeuterated $\mathrm{CHCl}_{3}\left(\delta_{\mathrm{H}} 7.27\right)$, while the center peak of the deuterated $\mathrm{CDCl}_{3}\left(\delta_{\mathrm{C}} 77.23\right)$ was used to reference the $\mathrm{C}-13$ spectra.

\section{LARVICIDAL BIOASSAY}

Aedes aegypti larvae of $3^{\text {th }}$ instar were collected at NUVET (Vectors Control Nucleus of Ceará State Health Secretary, Ceará, Brazil). The test against Aedes aegypti was performed by preparing samples in concentrations of 250,100, 50 and $25 \mu \mathrm{g} / \mathrm{mL}$ using DMSO $(0.3 \mathrm{~mL})$ to solubilize the oil in water $(19.7 \mathrm{~mL})$ that contained 50 larvae $\left(3^{\text {th }}\right.$ instar) (Cavalcanti et al. 2004). The test was performed in triplicate and after 24 hours of incubation, the dead larvae were counted for determination of $\mathrm{LC}_{50}$ (lethal concentration to kill $50 \%$ of the larvae).

\section{STATISTICAL ANALYSIS}

The experiments were performed in triplicate, and the results were expressed as mean and standard deviation (SD). The one-way ANOVA with the Tukey test was performed followed of comparisons testing for normal and homogeneous data, and when not, the Kruskal-Wallis test, Fisher's LSD multiple-posttest was used. The data were considered significant with p values below 0.05 .

\section{RESULTS AND DISCUSSION}

\subsection{CHEMICAL ANALYSIS}

The yields of essential oils were $0.30 \%$ for Curcuma longa and Curcuma zedoaria. Vieira and Simon (2000) explained that the yield of the essential oil depends on plant species, climatic and geographical areas, extraction and factors related to the plant, stage of maturation, and storage or preservation of the plant.

Table 1 displays the chemical composition of Curcuma longa and Curcuma zedoaria grown in Fortaleza, CE, Brazil. The gas chromatogram (Figure 2.1) shows peaks correspondent to compounds in order of retention time. The $C$. longa rhizome presented 14 compounds with $100 \%$ of the total identified, containing $\alpha$-turmerone $(33.09 \%)$, 
eucalyptol (17.70\%), $\alpha$-phellandrene (14.25\%), $\beta$-turmerone (13.82\%), ar-turmerone $(10.42 \%)$ and minor constituents such as terpinolene and para-cymene. The $C$. zedoaria essential oil presented 25 compounds, representing $95.21 \%$ of the total identified, and as major constituents: eucalyptol (45.37\%), camphor (15.71\%) and curzerenone $(13.55 \%)$.

The chemical analysis of the essential oils of $C$. longa obtained from plants of different locations shows differences in the composition with ar-turmerone as main constituents, followed by smaller amounts of $\alpha$ - and $\beta$-turmerone (Singh et al. 2010, Ferreira et al. 2013, Ali et al. 2015, Abdel-Lateef et al. 2016, Kumar et al. 2016, Hu et al. 2017, Avanço et al. 2017), differing from the findings of this study. For Curcuma longa grown in India, Kumar et al. (2018) revealed the presence of 11 compounds, representing $90.29 \%$ of the oil, in which terpinolene (52.88\%) and $\alpha$-phellandrene $(21.13 \%)$ are the main components.

For Curcuma zedoaria in plants from India, Mau et al. (2003) found epicurzerenone and curzerene in the first and second largest amounts (24.1 and 10.4\%). In another study with the oil of $C$. zedoaria, $\alpha$-terpinyl acetate (8.4\%), isoborneol (7\%), dehydrocurdione (9\%) and selina-4(15),7(11)-dien-8-one (9.4\%) were the main constituents of the leaf essential oil (Garg et al. 2011). In Curcuma zedoaria essential oils from Taichung (Taiwan), Chen et al. (2013) found 8,9-Dehydro-9-formyl-cycloisolongifolene, 6-ethenyl4,5,6,7-tetrahydro-3,6-dimethyl-5-isopropenyl-trans-benzofuran, eucalyptol, and $\gamma$ elemene. 
Table 1. Chemical composition of $C$. longa and C. zedoaria essential oils

\begin{tabular}{|c|c|c|c|c|}
\hline Chemical composition & KI lit & $\begin{array}{l}\mathrm{KI} \\
\exp \end{array}$ & $\begin{array}{c}\text { Curcuma longa } \\
(\%)\end{array}$ & $\begin{array}{c}\text { Curcuma } \\
\text { zedoaria }(\%)\end{array}$ \\
\hline Alpha-pinene & 939 & 928 & - & 0.80 \\
\hline Camphene & 954 & 942 & - & 1.46 \\
\hline Beta-pirene & 979 & 969 & - & 1.79 \\
\hline Myrcene & 991 & 984 & - & 0.70 \\
\hline Alpha-phellandrene & 1003 & 1002 & 14.25 & - \\
\hline para-Cymene & 1025 & 1022 & 2.04 & - \\
\hline Sylvestrene & 1031 & 1026 & 0.90 & - \\
\hline 1,8-cineole (Eucalyptol) & 1031 & 1029 & 17.70 & 45.37 \\
\hline Gamma-terpinene & 1060 & 1058 & 0.58 & - \\
\hline Terpinolene & 1089 & 1089 & 3.74 & - \\
\hline 2-nonanone & 1090 & 1091 & - & 0.38 \\
\hline Camphor & 1146 & 1150 & - & 15.71 \\
\hline Isoborneol & 1162 & 1163 & - & 3.19 \\
\hline Borneol & 1169 & 1172 & - & 1.05 \\
\hline Terpinen-4-ol & 1177 & 1184 & - & 1.00 \\
\hline Alpha-terpineol & 1189 & 1199 & 0.77 & 2.20 \\
\hline Beta-elemene & 1391 & 1408 & - & 2.01 \\
\hline E-caryophylene & 1409 & 1435 & - & 0.38 \\
\hline Z-beta-farnesene & 1443 & 1469 & - & 2.19 \\
\hline Germacrene-D & 1485 & 1495 & - & 0.72 \\
\hline Alpha-zingiberene & 1494 & 1502 & 0.77 & - \\
\hline Curzerene & 1499 & 1510 & - & 1.38 \\
\hline Beta-sesquiphellandrene & 1523 & 1528 & 0.63 & - \\
\hline Ar-turmerol & 1583 & 1578 & 0.64 & - \\
\hline Curzerenone & 1606 & 1612 & - & 13.55 \\
\hline Beta-atlantol & 1608 & 1627 & 0.65 & - \\
\hline Ar-turmerone & 1669 & 1655 & 10.42 & - \\
\hline Alpha-turmerone & 1680 & 1659 & 33.09 & - \\
\hline Beta-turmerone & 1681 & 1685 & 13.82 & - \\
\hline Curcumenol & 1734 & 1730 & - & 0.76 \\
\hline Selina-1,3,7 (11)-trien-8-one-epoxi & 1748 & 1763 & - & 1.31 \\
\hline$\%$ Total identified & & & 100.00 & 95.21 \\
\hline
\end{tabular}


Figure 2.1 GC-MS total ion chromatograms for essential oils of Curcuma longa and Curcuma zedoaria.

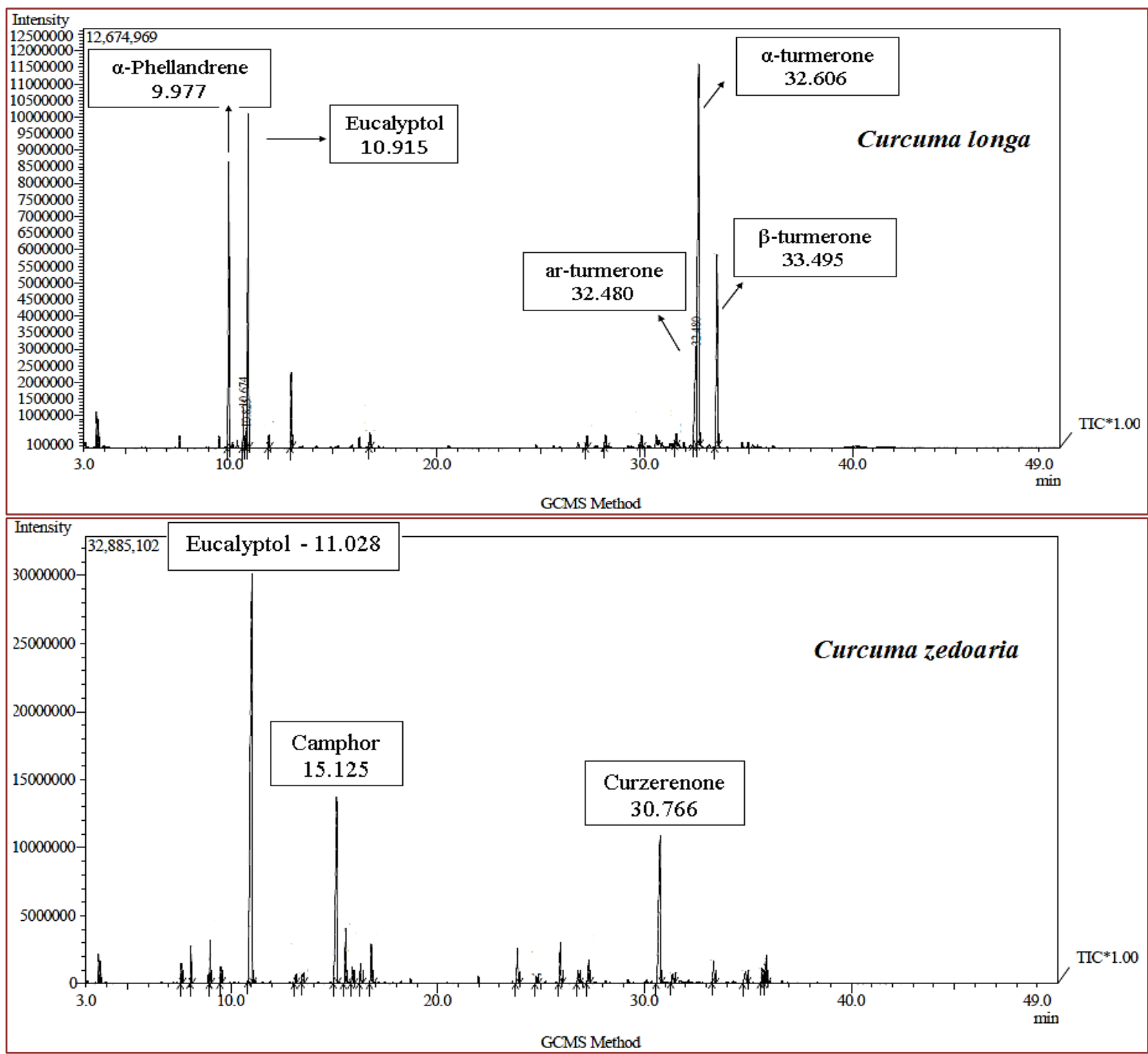

The species variability can cause changes in their chemical composition and activities. Variations in the chemical composition of plants essential oils occur due to changes in abiotic factors such as plant location, season of the year and even the time of day (Nogueira-Sobrinho et al. 2016).

All essential oils were examined by ${ }^{1} \mathrm{H}-\mathrm{NMR}$ analysis for confirmation of the main chemical constituents (Figure 2.2). The major peaks of the essential oil of the white variety are those from the methyl groups of carbon 7 at $1.09 \mathrm{ppm}$ and carbons 9 and 10 at 1.28 ppm according to the published data (http://www.hmdb.ca/spectra/nmr_one_d/2000). In the essential oil of the red variety the ${ }^{1} \mathrm{H}-\mathrm{NMR}$ spectrum showed in $7.11 \mathrm{ppm}$ the absorption of four aromatic hydrogens of the para-dissubstituted benzene ring of ar-turmerone, at 6.02-6.07 ppm of the double 
bonded hydrogen, the methyl group attached to the aromatic ring at $2.31 \mathrm{ppm}$, and singlets at 1.88, 1.85 and 1.86 ppm of methyl groups of carbon 13 and at 2.09, 2.10 and 2.13 ppm for methyl groups of carbon 12 for the three turmerones (Golding and PomboVillar 1992, Megumi et al. 2017).

Figure 2.2. ${ }^{1} \mathrm{H}$ NMR spectra of Curcuma longa (A) and Curcuma zedoaria (B) and structures of main constituents, solvent $\mathrm{CDCl}_{3}, 300 \mathrm{MHz}$.

A

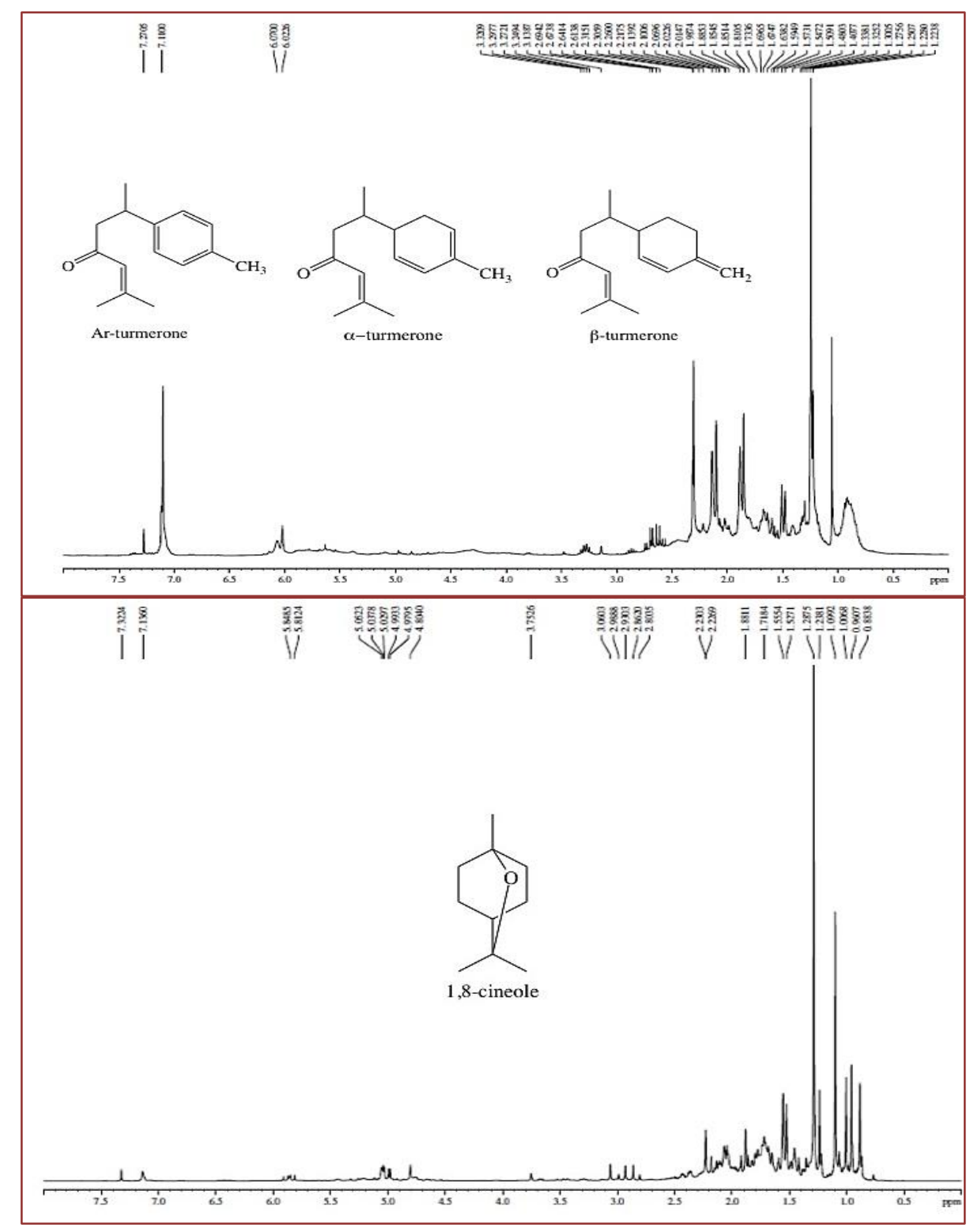




\subsection{ACTIVITY AGAINST AEDES AEGYPTI}

Some studies have shown that the terpene components, alcohols and aldehydes of essential oils are mainly responsible for insecticidal or larvicidal activity (Lucia et al. 2005). Essential oils can also act as digestive and neurological enzymes as well as interact with the insect in tegument (Isman 2006). Kim et al. (2003) demonstrated the importance of the relationship between chemical structure and compound activity; reporting that, the higher the lipophilicity and larger penetration (Gomes et al. 2016).

A review of the literature revealed that 361 essential oils from 269 plant species were tested for their larvicidal activity against Aedes aegypti. More than $60 \%$ of these essential oils were considered active ( $\mathrm{LC}_{50}<100 \mathrm{mg} / \mathrm{L}$ ), and most of these active oils were derived from species belonging to Myrtaceae, Lamiaceae, and Rutaceae. Essential oils rich in phenylpropanoids, oxygenated sesquiterpenes, and monoterpene hydrocarbons were the most active (Dias and Moraes 2014). Curcuma is a genus belonging to Zingiberaceae family and main compounds present in the oils were oxygenated mono (1,8-cineole) and sesquiterpenes (curzerenone, ar-turmerone, $\alpha$ tumerone and $\beta$-turmerone). Therefore, new sources as food ingredients should be investigated for discovering of nontoxic biolarvicides.

Both Curcuma oils exhibit good action against Ae. aegypti larvae. However, C. zedoaria presented a better larvicidal activity with $\mathrm{LC}_{50}$ of $46.33 \pm 1.21$ e $\mathrm{LC}_{90}$ of $93.48 \pm 1.28$ $\mu \mathrm{g} / \mathrm{mL}$, corresponding 100\% of mortality (Table 2). Sukontason et al. (2004) reported insecticidal on insects by eucalyptol (1,8-cineole), the main constituent of $C$. zedoaria.

Essential oils of $C$. longa have been documented as insecticides against many species of insects, including members of order Diptera. Previous studies about C. longa demonstrated anti-inflammatory and anti-cancer effects, and fractionation of volatile oil from rhizomes provided ar-turmerone, which showed $100 \%$ mosquito action at a concentration of $50 \mu \mathrm{g} / \mathrm{mL}$ on Aedes aegypti larvae (Roth et al. 1998). 
Table 2. Larvicidal activity of essential oil of Curcuma longa and Curcuma zedoaria against $3^{\text {th }}$ instar of Aedes aegypti.

\begin{tabular}{|l|c|c|}
\hline \multicolumn{2}{|c|}{ Essential Oil } & \multicolumn{2}{c|}{ Larvicidal against Aedes aegypti } \\
\cline { 2 - 3 } C. longa & $\mathrm{LC}_{50}(\mu \mathrm{g} / \mathrm{mL})$ & $\mathrm{LC}_{90}(\mu \mathrm{g} / \mathrm{mL})$ \\
\hline C. zedoaria & $95.52 \pm 6.68^{\mathrm{a}}$ & $253.29 \pm 31.38^{\mathrm{a}}$ \\
\hline
\end{tabular}

Different small letters mean statistical differences among lines $(\mathrm{p}<0.05)$.

The Curcuma longa grown in Brazil showed a larvicidal activity in third instar larvae of Aedes aegypti with better action when compared to the results of Prajapati et al. (2005), with $\mathrm{LC}_{50}$ values of $226.9 \mu \mathrm{g} / \mathrm{mL}$. The variation can be done to differences in composition of Curcuma oil from different locations. The larvicidal action can cause cytopathological alterations, destruction of the midgut epithelial cells of Ae. aegypti as explained by $\mathrm{Yu}$ et al. (2015), and also dark larval after exposure to some natural products.

Luna et al. (2004) performed with Ae. aegypti using the diagnostic concentration (CD) 0.0125 ppm i.a. of the organophosphate temephos, resulted in 10\% survival and $90 \%$ mortality. The difficulty in exterminating Aedes aegypti in Brazil, especially in the Brazilian Northeast, is due to the accelerated growth of the urban population, tropical climate (hot and rainy), and reproductive characteristics of the mosquito in our territory. However, frequent and increasing use of temephos causes mosquito-resistant, being gradually replaced by plants.

In conclusion, the comparative study demonstrated that the larvicidal activity against Aedes aegypti of the essential oil of $C$. zedoaria presented better results, mainly due to the higher content in eucalyptol and camphor and both products present low toxicity against A. salina. Thus, the essential oils of Curcuma species cultivated in Brazil present good prospects of being a useful larvicide against Aedes aegypti. 


\section{REFERENCES}

Abdel-Lateef, E., F. Mahmoud, O. Hammam, E. El-Ahwany, E. El-Wakil, S. Kandil, H.A. Taleb, M. El-Sayed, H. Hassenein. 2016. Bioactive chemical constituents of Curcuma longa L. rhizomes extract inhibit the growth of human hepatoma cell line (HepG2). Acta Pharmaceutica, 66: 387-398.

Adams, R.P. 2007. Identification of essential oil components by Gas Chromatography /Mass Spectrometry, 4th Edition. USA: ALLURED.

Ali, A., Wang, Y.; Khan, I.A. 2015. Larvicidal and biting deterrent activity of essential oils of Curcuma longa, ar-turmerone, and curcuminoids against Aedes aegypti and Anopheles quadrimaculatus (Culicidae: Diptera). J Medical Entomology, 1: 1-8.

Association of Official Analytical (AOAC)., 1995. Official methods of analysis (16 th ed.). Gaithersburg, MD: AOAC International.

Avanço, G.B., Ferreira, F.D.; N.S. Bonfim, P.A.S.R. Santos, R.M. Peralta, T. Brugnari, C.A. Mallmann, B.A. Abreu Filho, J.M.G. Mikcha, M.Jr. Machinski. 2016. Curcuma longa L. essential oil composition, antioxidant effect, and effect on Fusarium verticillioides and fumonisin production. Food Control, 83: 806-813.

Cavalcanti, E.S., S.M. Morais, M.A. Lima and E.W. Santana. 2004. Larvicidal activity of essential oils from Brazilian plants against Aedes aegypti L. Memórias do Instituto Oswaldo Cruz 99: 541-544.

Chen, C.C., Y. Chen, Y.T. Hsi, C.S. Chang, L.F. Huang, C.T. Ho, T.D. Way, J.Y. Kao. 2013. Chemical constituents and anticancer activity of Curcuma zedoaria Roscoe essential oil against non-small cell lung carcinoma cells in vitro and in vivo. Journal of Agricultural and Food Chemistry, 27; 61(47): 11418-27.

Dall'Acqua, S., M. Stoccherob, I. Boschiero, M. Schiavon, S. Golobc, J. Uddin, D. Voinovich, S. Mammi, E. Schievano. 2016. New findings on the in vivo antioxidant activity of Curcuma longa extract by an integrated 1H NMR and HPLC-MS metabolomic approach. Fitoterapia 109: 125-131.

Dias, C.N., D.F.C. Moraes. 2014. Essential oils and their compounds as Aedes aegypti L. (Diptera: Culicidae) larvicides: review. Parasitology Research, 113: 565-592.

Ferreira, F.D., S.A.G. Mossini, F.M.D. Ferreira, C.C. Arrotéia, C.L. Costa, C.V. Nakamura, M. Machinski Jr. 2013. The inhibitory effects of Curcuma longa L. essential oil and curcumin on Aspergillus flavus link growth and morphology. The Scientific World J. 136: 1-6.

Garg, S.N., A.A. Naquvi, R.P. Bansal, J.R. Bahl, S. Kumar. 2011. Chemical Composition of the Essential oil from the leaves of Curcuma zedoaria Rosc. of Indian Origin. Journal of Essential Oil Research, 17:1, 29-31.

Golding, B.T.; Pombo-Villar, E. 1992. Structures of alpha-turmerone and beta-turmerone. Journal of the Chemical Society - Perkin Transactions, 1: 1519-1524.

Gomes, P.R.B., A.L.S. Silva, H.A. Pinheiro, L.L. Carvalho, H.S. Lima, E.F. Silva, R.P. Silva, C.H. Louzeiro, M.B. Oliveira, V.E.M. Filho. 2016. Avaliação da atividade larvicida do óleo essencial do Zingiber officinale Roscoe (gengibre) frente ao mosquito Aedes aegypti. Revista Brasileira de Plantas Medicinais, 18(2, Suppl. 1): 597-604.

Hu, Y., J. Zhang, W. Kong, G. Zhao and M. Yang. 2017. Mechanisms of antifungal and anti-aflatoxigenic properties of essential oil derived from turmeric (Curcuma longa L.) on Aspergillus flavus. Food Chemistry, 220: $1-8$

Isman, M. 2006. Botanical insecticides, deterrents, and repellents in modern agriculture and an increasingly regulated world. Annual Review of Entomology, 51: 45-66.

Kim, B.N., N.J. Kim, M.N. Kim, Y.S. Kim, J.H. Woo and J. Ryu. 2003. Bacteremia due to Tribe Proteeae: a review of 132 cases during a decade (1991-2000). Scandinavian Journal of Infectious Disease, 35: 98-103.

Kumar, K.N., M. Venkataramana, J.A. Allen, S. Chandranayaka, H.S. Murali and H.V. Batra. 2016. Role of Curcuma longa L. essential oil in controlling the growth and zearalenone production of Fusarium graminearum. LWT - Food Science and Technology, 69: 522-528.

Lai, E.Y.C., C.C. Chyau, J.L. Mau, C.C. Chen, Y.J. Lai, C.F. Shih, L.L. Lin. 2004. Antimicrobial activity and cytotoxicity of the essential oil of Curcuma zedoaria. The American Journal of Chinese Medicine, 32: 281290. 
Lucia, A., G.A. Audino, E. Seccacini, S. Licastro, E. Zerba,and H. Masuh. 2007. Larvicidal effect of Eucalyptus grandis essential oil and turpentine and their major components on Aedes aegypti larvae. Journal of the American Mosquito Control Association. 3: 299-303.

Luna, J.E.D., M.F. Martins, A.F. Anjos, E.F. Kuwabara, M.A. Navarro-Silva. 2004. Susceptibilidade de Aedes aegypti aos inseticidas temephos e cipermetrina, Brasil. Revista de Saúde Pública, 38: 842-843.

Mau, J.L., E.Y.C. Lai, N.P. Wang, C.C. Chen, C.H. Chang, C.C. Chyau, 2013. Composition and antioxidant activity of the essential oil from Curcuma zedoaria. Food Chemistry, 82: 583-591.

Megumi, C., K. Muroyama, H. Sasako, N. Tsuge. 2017. Preventive activity of ar-Turmerone and Bisacurone isolated from Turmeric Extract Against ethanol-Induced Hepatocyte Injury. Food Sci. Technol. Res. 23: 275-281.

Morais, S.M.; Cavalcanti, E.S.B.; Bertini, L.M.; Oliveira, C.L.L.; Rodrigues, J.R.B.; Cardoso, J.H.L. Larvicidal Activity of Essential Oils from Brazilian Croton Species against Aedes aegypti L. Journal of the American Mosquito Control Association, v. 22, n. 2, p. 161-164, 2006.

Nathan, S.S., K. Kalaivani, and K. Sehoon. 2006. Effects of Dysoxylum malabaricum Bedd. (Meliaceae) extract on the malarial vector Anopheles stephensi Liston (Diptera:Culicidae). Bioresource Technology, 97: 2077-2083.

Nogueira-Sobrinho, A.C., E.B. Souza, M.F.G. Rocha, M.R.J.R. Albuquerque, P.N. Bandera, H.S. Santos, R. Pereira, S.M. Morais, R.O.S. Fontenelle and C.S.P. Cavalcante. 2016. Cytotoxicity, antifungal and antioxidant activities of the essential oil from Eupatorium ballotifolium Kunth (Asteraceae). African Journal of Pharmacy and Pharmacology, 16: 346-355.

Phukerd, U. and M. Soonwera. 2013. Larvicidal and pupicidal activities of essential oils from Zingiberaceae plants against Aedes aegypti (Linn.) and Culex quinquefasciatus say mosquitoes. Southeast Asian Journal of Tropical Medicine and Public Health 44: 761-71.

Prajapati, V., A.K. Tripathi, K.K. Aggarwal and S.P.S. Khanuja. 2005. Insecticidal, repellent and ovipositiondeterrent activity of selected essential oils against Anopheles stephensi, Aedes aegypti and Culex quinquefasciatus. Bioresource Technology, 96: 1749-1757.

Roth, G.N., A. Chandra and M.G. Nair. 1998. Novel bioactivities of Curcuma longa constituents. Journal of Natural Products, 61: 542-545.

Shinobu-Mesquita, C.S., T.A. Bertoni, E. Guilhermetti, and T.I.E. Svidzinski, 2011. Antifungal activity of the extract of Curcuma zedoaria (Christm.) Roscoe, Zingiberaceae, against yeasts of the genus Candida isolated from the oral cavity of patients infected with the human immunodeficiency virus. Revista Brasileira de Farmacognosia, 21: 128-132.

Singh, G., I.P.S. Kapoor, P. Singh, C.S. Heluani, M.P. Lampasona, C.A.N. 2010. Catalan. Comparative study of chemical composition and antioxidant activity of freshand dry rhizomes of turmeric (Curcuma longa Linn.). Food and Chemical Toxicology, 48: 1026-1031.

Sukontason, K.L., N. Boonchu, K. Sukontason and W. Choochote 2004. Effects of eucalyptol on house fly (Diptera: Muscidae) and blow fly (Diptera: Calliphoridae). Revista do Instituto de Medicina Tropical, 46: 97-101.

Sutiningsih, D., Mustofa, T.B.T. Satoto and E. Martono, 2017. Inhibitory effects of bruceine A biolarvicideon growth and development of Aedes aegypti Larvae. Journal of Entomology, 14: 104-111.

Sutthanont, N., W. Choochote, B. Tuetun, A. Junkum, A. Jitpakdi, U. Chaithong, D. Riyong and B. Pitasawat. 2010. Chemical composition and larvicidal activity of edible plant-derived essential oilsagainst the pyrethroid-susceptible and -resistant strains of Aedes aegypti (Diptera: Culicidae). Journal of Vector Ecology, 35: 105-115.

Teixeira, R.R., W.L. Pereira, A.F. Oliveira, A.M. Silva, A.S. Oliveira, M.L. Silva, C.C. Silva and S.O. Paula. 2014. Natural products as source of potential dengue antivirals. Molecules 17; 19(6): 8151-76.

Widyowati, R and M. Agil. 2018. Chemical constituents and bioactivities of several Indonesian plants typically used in Jamu. Chemical and Pharmaceutical Bulletin, 66: 506-518.

Yu, K.X., C.L. Wong, R. Ahmad and I. Jantan. 2015. Larvicidal activity, inhibition effect on development, histopathological alteration and morphological aberration induced by seaweed extracts in Aedes aegypti (Diptera: Culicidae). Asian Pacific Journal of Tropical Medicine, 8: 1006-1012. 


\section{Chapter 3}

Intraspecific chemical composition variation and acetilcholinesterase inhibition activity of leaf essential oils from four Croton blanchetianus Baill specimens

\section{Dayane Lima Guerra}

Ana Livya Moreira Rodrigues

Daniela Ribeiro Alves

Edilberto Rocha Silveira

Selene Maia de Morais

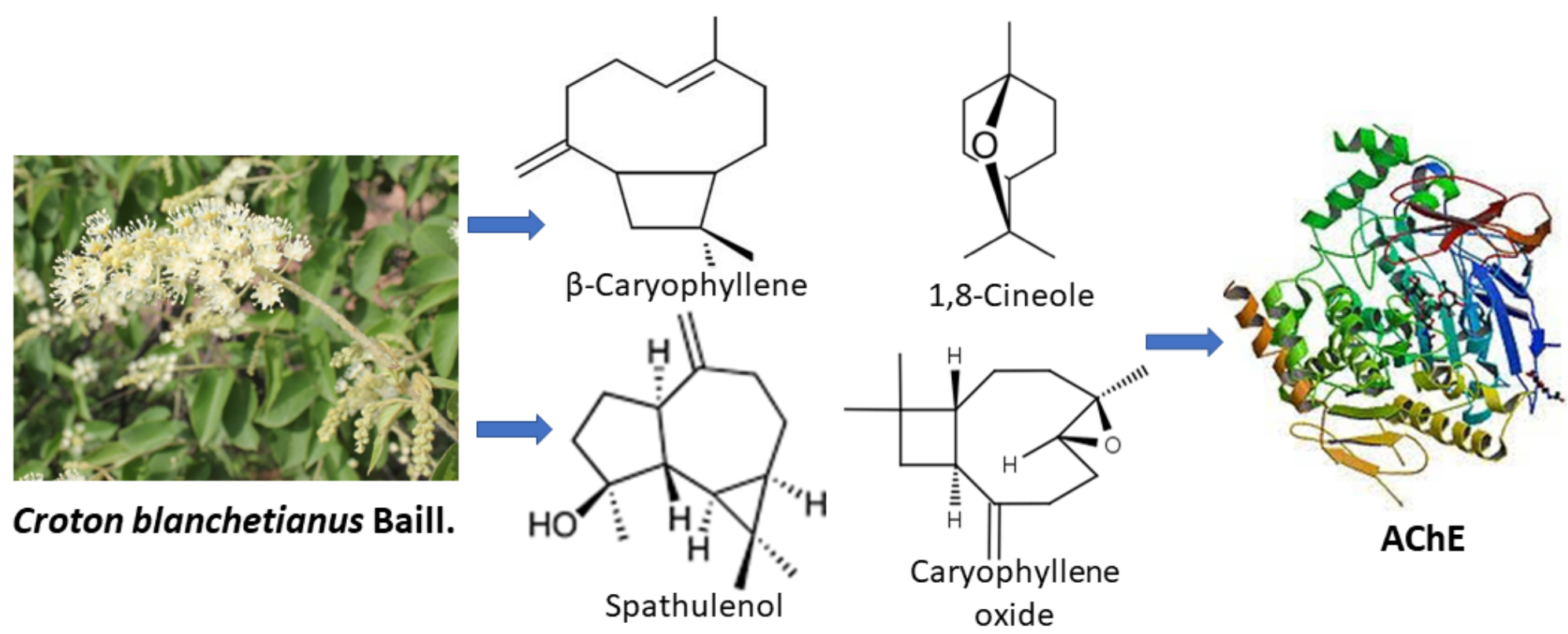




\section{INTRODUCTION}

In Brazil several medicinal plants were selected by the National Program of Medicinal Plants and Phytotherapics as the most promising for new studies. These included species of the genera Chenopodium, Equisetum and Croton (Souza et al., 2016). One of these species is Croton blanchetianus Baill. (syn. Croton sonderianus Muell Arg., which is found mainly in the Northeast region of Brazil, in the Caatinga biome (Cordeiro et al., 2016).

In ethnobotanical studies, this species is cited to prevent bleeding and treat liver ailments and stomach pain (Ribeiro et al., 2014). In pharmacological studies, the essential oil extracted from $C$. banchetianus showed antinociceptive activity in rats (Santos et al., 2005). It was demonstrated the bioactivity of $C$. blanchetianus essential oil on the Callosobruchus maculatus by reducing oviposition and emergence of adult (Silva et al, 2020). Another study conducted with C. blanchetianus essential oil against food pathogens showed a bactericidal effect against Aeromonas hydrophila and Listeria monocytogenes and a bacteriostatic action against Salmonella Enteritidis. A bacteriostatic effect on meat contaminated with $L$. monocytogenes was found for all concentrations of essential oils tested. Essential oil from the leaves of $C$. blanchetianus represents an alternative source of potentially natural antimicrobial agents that may be used as a food preservative (Melo et al., 2013). Due to the popular use and biological activities reported, $C$. blanchetianus deserve more studies.

Acetylcholinesterase catalyzes the hydrolysis of the neurotransmitter acetylcholine at neuronal synapses, and at neuromuscular junctions, at the end of the signaling process. In Alzheimer's disease (AD), acetylcholinesterase is present in higher concentration, then levels of acetylcholine in the brains are significantly diminished, which leads to weakened neurotransmission and thereby memory loss and other adverse effects. The cholinesterase enzyme may also be, at least partly, responsible for the buildup of amyloid $\beta$ plaques and the nervous system is more prone to oxidative stress and oxidative damage (Caetano et al., 2017; Araújo; Santos; Gonsalves, 2016). Thus, the symptoms of AD can be ameliorated by the inhibition of AChE using natural compounds found in plants, such as alkaloids and essential oils (VIEGAS et al., 2004). In addition, the use of antioxidants in the diet can reduce the risk of $\mathrm{AD}$ (Gemelli et al., 2013). 
Oxidative stress and free radicals are associated with several diseases, such as cancer, cardiovascular diseases, cataracts and neurodegenerative disorders (Sousa et al., 2007). Many medicinal plants are known for their ability to scavenge free radicals through the production of antioxidant secondary metabolites (Amri; Hossain, 2018). The production of these compounds is influenced by several factors, such as ultraviolet radiation, temperature, nutrients, soil pH and other environmental factors (Simões et al., 2010) besides genetic aspects of the species (Gobbo-Neto; Lopes, 2007).

Thus, this study aimed to determine the chemical composition and some biological activities of the leaf essential oils and ethanol extracts of $C$. blanchetianus. Four specimens were collected in the same conditions, to evaluate possible intraspecific variations that can influence the biological activities as antioxidants and inhibition of AChE, looking for potential sources of compounds to fight Alzheimer's disease.

\section{MATERIALS AND METHODS}

The four specimens of C. blanchetianus were collected in April 2018, in the Bixopá district of the city of Limoeiro do Norte, Ceará, Brazil. The specimens were collected between 9 am and 10 am in a straight line, 20 meters apart. The species was identified by the botanist L.W. Lima-Verde of the Prisco Bezerra Herbarium of Federal University of Ceará, and registered under number EAC 47159.

The essential oils from the leaves of the four specimens of $C$. blanchetianus were extracted by the hydrodistillation process individually with a Clevenger apparatus, maintained in the system for 2 hours to obtain the oils, which were dried with anhydrous sodium sulfate and kept under refrigeration until analysis.

The four oils were subjected to gas chromatography coupled to mass spectrometry for the identification of the components. The chemical analyses of the essential oils were performed with a Shimadzu QP-2010 Ultra instrument, using the following conditions: column: Rtx-5MS (crossbond 5\%, diphenyl/95\% dimethylpolysiloxane) with 30m x $0.25 \mathrm{~mm} \times 0.25 \mu \mathrm{m} \mathrm{df}$; carrier gas: He (24.2 $\mathrm{mL} / \mathrm{min}$, at constant linear velocity); injector temperature of $250{ }^{\circ} \mathrm{C}$, in split mode (1:100), and detector temperature of $250{ }^{\circ} \mathrm{C}$. The column temperature was programmed from $35-180{ }^{\circ} \mathrm{C}$ at $4{ }^{\circ} \mathrm{C} / \mathrm{min}$ and $180-280{ }^{\circ} \mathrm{C}$ at $17{ }^{\circ} \mathrm{C} / \mathrm{min}$ and kept at $280{ }^{\circ} \mathrm{C}$ for 10 minutes. The mass spectra were obtained by 
electron impact at $70 \mathrm{eV}$. The sample was injected in $1 \mu \mathrm{L}$ volume. The compounds were identified by their relative retention times in GC, compared with the NIST database and by visual comparison of mass spectra with those from a data catalog (ADAMS, 2012). Then, the essential oils were subjected to analysis to quantify the inhibitory capacity of acetylcholinesterase, which is associated with symptoms of Alzheimer's disease. The method involved an BIOTEK Elisa reader, model ELX 800, with the Gen5 V2.04.11 software and a 96-well plate containing the following solutions: $25 \mu \mathrm{L}$ of acetylthiocholine iodide (15 mM), $125 \mu \mathrm{L}$ of 5,5'-Dithiobis-[2-nitrobenzoic acid] in Tris/ $\mathrm{HCl}$ solution (50nM, $\mathrm{pH}=8$, with $0.1 \mathrm{M} \mathrm{NaCl}$ and $0.02 \mathrm{M} \mathrm{MgCl}_{2} .6 \mathrm{H}_{2} \mathrm{O}$ (3mM, DTNB or Ellman's reagent)), $50 \mu \mathrm{L}$ of the Tris/ $\mathrm{HCl}$ solution $(50 \mathrm{nM}, \mathrm{pH}=8$, with $0.1 \%$ bovine serum albumin (BSA)) (ELLMAN et al., 1961). In addition, the oils were added at a concentration of $2 \mathrm{mg} / \mathrm{mL}$, dissolved in methanol, and a serial dilution was performed to the concentration of $0.2 \mathrm{mg} / \mathrm{mL}$. Thus, a first reading was made at a wavelength of 450 nm for 30 seconds, then $25 \mu \mathrm{L}$ of acetylcholinesterase $\left(0.25 \mathrm{U}^{-\mathrm{mL}^{-1}}\right)$ was added and absorbance was read every minute for 25 minutes. The results of acetylcholinesterase inhibitory activity were submitted to analysis of variance (ANOVA), followed by the Tukey test at significance of 5\% for comparison between specimens. For these tests, GraphPad Prism version 5.01 was used.

\section{RESULTS AND DISCUSSION}

In the GC/MS analysis, 52 constituents were tentatively identified in the four essential oils by comparison of their retention times - Kovat's index and mass spectrum with those displayed in the Adams' book (2012) of essential oil components. The relative percentual composition was obtained observing the peak area for each component in the gas chromatogram. Significant differences were observed in the types and contents of the major compounds of each oil. In the essential oil the specimen 1 (EOCB1), the main compounds were D-limonene (12.41\%), $\beta$-caryophyllene (10.35\%), spathulenol (25.37\%) and caryophyllene oxide (14.67\%); in the essential oil from specimen 2 (EOCB2) the main compounds were 1,8-cineole (7.01\%), $\beta$-caryophyllene $(6.02 \%)$, germacrene B (12.73\%) and aristolene (16.09\%); in the essential oil from specimen 3 (EOCB3) the main ones were $\alpha$-barbatene (11.77\%), caryophyllene $(11.49 \%)$, spathulenol (12.82\%) and caryophyllene oxide (13.8\%); and the essential oil from 
specimen 4 (EOCB4) the main constituents were 1,8-cineole (26.70\%), spathulenol (12.90\%) and caryophyllene oxide (21.25\%). The complete results are reported in Table 1.

As observed in table 1, there was a substantial variation both quantitatively and qualitatively of the chemical composition of the four oils. Some major compounds like $\alpha$ barbatene, which is present only in EOCB3, and germacrene B and aristolene only in EOCB2, among others. In addition, different contents of the compounds occurred in more than one essential oil, such as caryophyllene, which in EOCB1 presented $10.35 \%$ and in EOCB4 was 1.37\%.

These chemical differences observed in essential oils of the same species can be explained by several factors. Among them are environmental conditions, which are directly linked to the production of secondary metabolites in the plant, like temperature, soil, luminosity and presence of pathogens. In addition, another factor that causes changes both in the yield and types of compounds in the oils is the intraspecific genetic variations of the plants, which affects their biological activities. (Simões et al., 2010; Gobbo-Neto; Lopes, 2007). Thus, we believe these chemical differences present in the four $C$. blanchetianus essential oils is due to intraspecific variations, since the specimens were collected in the same place.

The leaf essential oils from 62 specimens of Myracrodruon urundeuva were analyzed and six different chemotypes were characterized, nevertheless the variation was not related to the harvest time or habitat (De Aquino; Araújo; Silveira, 2017). In another study, among the essential oils extracted from 31 populations of Lippia integrifolia, many differences were observed among them, being defined five chemotypes, associating the variation of the composition to the genetic factor (Marcial et al., 2016). 
Table 1. Percentage composition of essential oils from the leaves of four Croton blanchetianus specimens (EOCB).

\begin{tabular}{|c|c|c|c|c|c|c|}
\hline Constituents & KILit & KICal & EOCB1 $(\%)$ & EOCB2 $(\%)$ & EOCB3 (\%) & EOCB4 (\%) \\
\hline$\alpha$-Pinene & 939 & 933 & - & 0.51 & - & 1.5 \\
\hline Sabinene & 975 & 972 & - & - & - & 1.69 \\
\hline$\beta$-Pinene & 979 & 975 & - & - & - & 0.48 \\
\hline$\beta$-Myrcene & 990 & 990 & - & 1.81 & - & 4.78 \\
\hline$p$-Cymene & 1024 & 1024 & 3.87 & - & - & 1.66 \\
\hline D-Limonene & 1029 & 1020 & 12.41 & - & - & - \\
\hline 1,8-Cineole & 1031 & 1030 & - & 6.56 & 5.3 & 26.70 \\
\hline 2-Heptanol, acetate & 1034 & 1040 & - & - & - & 1.13 \\
\hline Linalool & 1096 & 1094 & 1.1 & - & - & - \\
\hline cis- $\beta$-Terpineol & 1144 & 1140 & - & - & - & 2.61 \\
\hline Borneol & 1169 & 1174 & - & - & - & 1.24 \\
\hline Terpinen-4-ol & 1177 & 1178 & 1.52 & - & 1.22 & 0.81 \\
\hline$p$-Cymen-8-ol & 1182 & 1188 & 3.60 & - & - & - \\
\hline Cryptone & 1185 & 1190 & - & - & 0.98 & - \\
\hline$\alpha$-Terpineol & 1188 & 1193 & 0.72 & 0.96 & 5.56 & 4.09 \\
\hline Myrtenol & 1195 & 1207 & - & - & - & 0.85 \\
\hline$\delta$-Elemene & 1338 & 1350 & - & 0.90 & - & - \\
\hline Cyclosativene & 1371 & 1368 & - & - & 0.8 & 0.62 \\
\hline$\alpha$-Copaene & 1376 & 1383 & 0.66 & - & - & - \\
\hline$\beta$-Bourbonene & 1388 & 1389 & 1.1 & 0.38 & 1.07 & 1.06 \\
\hline$\beta$-Elemene & 1390 & 1399 & 1.17 & 2.60 & - & 1.73 \\
\hline$\alpha$-Barbatene & 1407 & 1412 & - & - & 11,77 & - \\
\hline E-Caryophyllene & 1419 & 1424 & 10.35 & 5.63 & 11.49 & 1.37 \\
\hline Aromadendrene & 1441 & 1444 & 0.45 & - & 0.84 & - \\
\hline$\alpha$-Humulene & 1454 & 1458 & 2.71 & - & - & - \\
\hline$\gamma$-Muurolene & 1479 & 1480 & - & 4.24 & - & - \\
\hline Eudesma-4(14),11-diene & 1483 & 1481 & 2.4 & - & 4.82 & - \\
\hline$\gamma$-Gurjunene & 1485 & 1482 & - & - & 4.9 & - \\
\hline Guaia-1(10),11-diene & 1488 & 1490 & - & - & 0.94 & - \\
\hline$\alpha$-Muurolene & 1497 & 1491 & 1.1 & 1.83 & 1.72 & - \\
\hline$\alpha$-Selinene & 1498 & 1497 & 1.39 & - & - & - \\
\hline 4- Epi-Cubebol & 1500 & 1499 & - & - & 5.89 & 4.53 \\
\hline Trans-Calamenene & 1509 & 1500 & - & 4.69 & 1.08 & \\
\hline$\gamma$-Cadinene & 1515 & 1520 & 0.93 & 2.48 & - & - \\
\hline$\delta$-Cadinene & 1523 & 1523 & 0.35 & 0.92 & - & - \\
\hline Germacrene B & 1559 & 1550 & - & 11.91 & & \\
\hline Spathulenol & 1577 & 1577 & 25.37 & 1.20 & 12.82 & 12.90 \\
\hline Caryophyllene Oxide & 1583 & 1580 & 14.67 & - & 13.8 & 21.25 \\
\hline Aristolene & 1585 & 1587 & - & 15.05 & - & - \\
\hline Viridiflorol & 1593 & 1590 & - & - & 2.28 & - \\
\hline Ledol & 1599 & 1595 & 0.79 & 2.87 & - & - \\
\hline$\delta$-Cedrol & 1603 & 1610 & - & - & 0.96 & - \\
\hline Selina-6-en-4-ol & 1624 & 1630 & 0.77 & - & - & - \\
\hline Germacrene D-4-ol & 1626 & 1632 & - & 2.94 & - & - \\
\hline Xantoxilyn & 1650 & 1645 & 3.45 & - & - & - \\
\hline
\end{tabular}


Table 1. Percentage composition of essential oils from the leaves of four Croton blanchetianus specimens (EOCB)(Continuation).

\begin{tabular}{|l|c|c|c|c|c|c|}
\hline \multicolumn{1}{|c}{ Constituents } & \multicolumn{1}{c}{ KILit } & \multicolumn{1}{c|}{ KICal } & \multicolumn{1}{c|}{ EOCB1 (\%) } & \multicolumn{1}{c|}{ EOCB2 (\%) } & EOCB3 (\%) & EOCB4 (\%) \\
\hline$\delta$-Cadinol & 1654 & 1654 & - & 0.66 & - & - \\
\hline Isolongifolen-5-one & 1685 & 1660 & - & 2.60 & - & - \\
\hline Khusimol & 1747 & 1740 & - & 2.51 & - & - \\
\hline Guaiazulene & 1781 & 1772 & - & 2.79 & - & - \\
\hline \multicolumn{1}{|c|}{ TOTAL } & & & 90.88 & 76.03 & 88.24 & 90.00 \\
\hline
\end{tabular}

The order of compounds is displayed according to their retention times in a non-polar columnRtx-5MS. KILit = Kovats Index from the literature; KICal = Kovats Index calculated by linear regression using the compounds in highest proportion in the oils.

The results of the acetylcholinesterase inhibition test were shown in Table 2. The four essential oils revealed good results as compared to the standard physostigmine but with significative differences among them.

Table 2. Inhibitory activity of acetylcholinesterase by the four essential oils of Croton blanchetianus

\begin{tabular}{|c|c|c|c|c|c|}
\hline & PHYS & EOCB1 & EOCB2 & EOCB3 & EOCB4 \\
\hline $\mathrm{IC}_{50}$ & $1.15 \pm$ & $10.31 \pm$ & $15.53 \pm$ & $6.59 \pm$ & $11.98 \pm$ \\
$(\mu \mathrm{g} / \mathrm{mL})$ & $0.05^{\mathrm{a}}$ & $0.03^{\mathrm{c}}$ & $0.03^{\mathrm{e}}$ & $0.19^{\mathrm{b}}$ & $0.53^{\mathrm{d}}$ \\
\hline
\end{tabular}

$\mathrm{IC}_{50}=50 \%$ inhibitory concentration of the enzyme acetylcholinesterase, PHYS = physostigmine.

The relevant activity of the essential oils for AChE inhibition is associated with some compounds present, such as: 1,8-cineole, $\alpha$-pinene, $\beta$-myrcene, terpine-4-ol, limonene and E-caryophyllene (Souza, et al., 2012; Burcul et al., 2019). These compounds were present in most oils, explaining their good activity, since the anticholinesterase potency was classified in three categories in accordance to their $\mathrm{IC}_{50}$ values: high potency, $\mathrm{IC}_{50}<$ $20 \mu \mathrm{g} / \mathrm{mL}$; moderate potency, $20<\mathrm{IC}_{50}<200 \mu \mathrm{g} / \mathrm{mL}$; and low potency, $200<\mathrm{IC}_{50}<$ $1,000 \mu \mathrm{g} / \mathrm{mL}$. (Santos et al, 2018). In addition, in a previous study synergism in the inhibition of this enzyme was found between the compounds 1,8-cineole and caryophyllene oxide, present in oils EOCB3 and EOCB4 (Savelev et al., 2003). Although EOCB1 did not contain 1,8-cineole, one of the main compounds with activity was Dlimonene, which has previously been found to inhibit AChE (Souza et al., 2012).

E-caryophyllene (BCAR) is a major sesquiterpene of various plant essential oils reported for several important pharmacological activities, including antioxidant, anti- 
inflammatory, anticancer, cardioprotective, hepatoprotective, gastroprotective, nephroprotective, antimicrobial, and immune-modulatory activity. Recent studies suggest that it also possesses neuroprotective effect. Additionally, BCAR has local anesthetic-like activity, which could protect the nervous system from oxidative stress and inflammation and can act as an immunomodulatory agent then there is a possible application of BCAR as a neuroprotective agent (Machado et al., 2018). All of these findings suggest that $\beta$-caryophyllene has a potent neuroprotective activity, and its neuroprotection may be partly related to the modulation of inflammatory mediators.

Eugenia pyriformis essential oil presented a biocidal potential of in the control of Rhipicephalus (Boophilus) microplus in the free-living cycle. The mechanism of action through which killed the larvae and adult females was investigated by the Bioautographic Method, which showed inhibition of $3.15 \mathrm{mg} / \mathrm{mL}$ of the EO on the acetylcholinesterase (AChE) enzyme. Main constituents of the oil were spathulenol (43.65\%) and caryophyllene oxide (12.17\%) (Medeiros et al., 2019).

Sage (Salvia spp) is reputed in European herbal encyclopaedias to enhance memory, and current memory-enhancing/anti-dementia drugs are based on enhancing cholinergic activity by inhibiting cholinesterase. The effects of Salvia lavandulaefolia Vahl. (Spanish sage) essential oil and some of its constituent terpenes on human erythrocyte acetylcholinesterase were examined in-vitro. The essential oil, 1,8-cineole and alphapinene were most actives (Perry et al, 2000).

\section{CONCLUSIONS}

The essential oils of $C$. blanchetianus showed good activity in the inhibition of the enzyme acetylcholinesterase. This opens possibilities for the plant's leaves to be used to prevent memory deficits. In this respect, other studies have already demonstrated the effect of the essential oil of this species on the nervous system through the antinociceptive action. In addition, this species presented intraspecific variations in the production of secondary metabolites, significantly influencing their biological activities. Thus, for a desired use as anticholinesterase agent, $C$. blanchetianus specimens with essential oils rich in $\beta$-caryophyllene, caryophyllene, spathulenol and 1,8-cineole should be domesticated for future studies in this medical area. 


\section{REFERENCES}

Adams, R.P. 2012. Identification of essential oil components by gas chromatography/mass spectrometry. [S.l.]: Carol Stream, IL: Allured Publishing corporation

Amri, F.S.; Hossain, M.A. 2018. Comparison of total phenols, flavonoids and antioxidant potential of local and imported ripe bananas. Egyptian Journal of Basic and Applied Sciences, v. 5, n. 4, p. 245-251.

Araújo, C.R.M.; Santos, V.L.A.; Gonsalves, A.A. 2016. Acetilcolinesterase - AChE: Uma Enzima de Interesse Farmacológico. Revista Virtual de Quimica, v. 8, n. 6, p. 1818-1834.

Araújo-Filho, J.V.; Ribeiro, W.L.C.; André, W.P. Cavalcante, G. S.; Rios, T.T.; Schwinden, G.M.; Rocha, L.O.; Macedo, I.T.F.; Morais, S.M.; Bevilaqua, C.M.L.; Oliveira, L.M.B. 2019. Anthelmintic activity of Eucalyptus citriodora essential oil and its major component, citronellal, on sheep gastrointestinal nematodes. Revista Brasileira de Parasitologia Veterinária, v. 28, p. 644-651.

Burcul, F.; Burčul, F., Blažević, I., Radan, M., Politeo, O. 2019. Terpenes, Phenylpropanoids, Sulfur and other essential oil constituents as Inhibitors of cholinesterases. Current Medicinal Chemistry, v. 26, n. 42, p. 155.

Caetano, 0.; Da Silva, F. S.; Silveira, C. A. B. 2017. Alzheimer, sintomas e grupos: uma revisão integrativa. VINCULO - Revista do NESME, v. 14, n. 2, p. 84-93.

Cordeiro, I.; Secco, R.; Carneiro-Torres, D.S.; Lima, L.R.; Caruzo, M.B.R.; Berry, P.; Riina, R.; Silva, O.L.M; Silva, M.J.; Sodré, R.C. 2016. Croton In Lista de Espécies da Flora do BrasiL. In: Jardim Botânico do Rio de Janeiro. [S.l: s.n.].

De Aquino, N.C.; Araújo, R.M.; Silveira, E. 2017. Intraspecific variation of the volatile chemical composition of Myracrodruon urundeuva Fr. Allem. ("aroeira-do-sertão"): Characterization of six chemotypes. Journal of the Brazilian Chemical Society, v. 28, n. 5, p. 907-912.

Ellman, G.L.; Courtney, K.D., Andres Jr, V., Featherstone, R.M. 1961. A new and rapid colorimetric determination of acetylcholinesterase activity. Biochemical Pharmacology, v. 7, p. 88-95.

Gemelli, T.; Andrade, R.B.; Castro, Al.; Garcia, L. P.; Funcha, C. 2013. Estresse Oxidativo como Fator Importante na Fisiopatologia da doença de Alzheimer. Revista Uniara, v. 16, n. 1, p. 67-78.

Gobbo-Neto, L.; Lopes, N.P. 2007. Plantas Medicinais: Fatores de Influência no Conteúdo de metabólitos secundários. Quimica Nova, v. 30, n. 2, p. 374-381,

Machado, K.C.; Islam, M. T.; Ali, E.S.; Rouf, R.; Uddin, S.J.; Dev, S.; Shilpi, J.A.; Shill, M.C.; Reza, H. M.; Das, A. K.; Shaw, S.; Mubarak, M.S.; Mishra, S.K.; Melo-Cavalcante, A.A.C. 2018. A systematic review on the neuroprotective perspectives of beta-caryophyllene. Phytotherapy Research, v. 32, n. 12, p. 2376-2388.

Marcial, G.; Lampasona, M.P.; Vega, M.I.; Lizarraga, E.; Viturro, C.I.; Slanis, A; Juárez, M.A.; Elechosa, M.A.; Catalána, C.A.N. 2016. Intraspecific variation in essential oil composition of the medicinal plant Lippia integrifolia (Verbenaceae). Evidence for five chemotypes. Phytochemistry, v. 122, p. 203-212.

Medeiros, J.P.; Bortollucci, W.C.; Silva, E. Gonçalves, S., Herika L.M. Oliveira, Caio F.A.A. Campo, J. E.; P. Junior, R.; Gazim, Z.C. Biocidal potential of Eugenia pyriformis Cambess essential oil in the control of Rhipicephalus (Boophilus) microplus in the free-living cycle. Pesq. Vet. Bras. v. 39, n. 11, p. 879-888, 2019.

Perry NS, Houghton PJ, Theobald A, Jenner P, Perry EK. In-vitro inhibition of human erythrocyte acetylcholinesterase by salvia lavandulaefolia essential oil and constituent terpenes. J Pharm Pharmacol. 2000 Jul;52(7):895-902.

Ribeiro, D.A.; Macêdo, D.G.; Oliveira, L.G.S.; Saraiva, M.E.; Oliveira SF.; Souza, M.M.A.; Menezes, I.R.A. Potencial terapêutico e uso de plantas medicinais em uma área de Caatinga no estado do Ceará, nordeste do Brasil. Revista Brasileira de Plantas Medicinais, v. 16, n. 4, p. 912-930, 2014.

Santos, F.A.; Jeferson, F.A.; Santos, C.C.; Silveira, E. R.; Rao, V.S.N. 2005. Antinociceptive effect of leaf essential oil from Croton sonderianus in mice. Life Sciences, v. 77, n. 23, p. 2953-2963.

Santos, T. C.; Gomes, T. M.; Pinto, B. A. S.; Camara, A. L.; Paes, A. M. A. 2018. Naturally occurring acetylcholinesterase inhibitors and their potential use for Alzheimer's disease therapy. Frontiers in Pharmacology, v. 18, n. 9, 1192.

Savelev, S.; Okello, E.; Perry, N.S.L.; Wilkins, R.M.; Perry, E.K. 2003. Synergistic and antagonistic interactions of anticholinesterase terpenoids in Salvia lavandulaefolia essential oil. Pharmacology 
Biochemistry and Behavior, v. 75, n. 3, p. 661-668.

Simões, C.M.O., Schenkel, E.P., Gosmann, G., Mello, J.C.P., Mentz, L.A., Pedrovick, P.R. , 2010. Farmacognosia: da planta ao medicamento. 6. ed. [S.l.]: UFRGS: Porto Alegre.

Sousa, C M.M.; Silva, H.R.; Ayres, M.C.C.; Costa, C.L.S.D.; Araújo, D.S.; Cavalcante, L.C.D.; Barros, E.D.S.; Araújo, P.B.M.; Brandão, M.S.; Chaves, M.H. 2007. Fenóis totais e atividade antioxidante de cinco plantas medicinais. Quimica Nova, v. 30, n. 2, p. 351-355.

Souza, L.F.; Dias, R.F.; Guilherme, F.A.G.; Coelho, C.P. 2016. Plantas medicinais referenciadas por raizeiros no município de Jataí, estado de Goiás. Revista Brasileira de Plantas Medicinais, v. 18, n. 2, p. 451-461.

Souza, S.P.; Valverde, S.S.; Silva, R.L.; Lima, K.S.; Lima, A.L. 2012. Óleos Essenciais como Inibidores da acetilcolinesterase. Revista Fitos, v. 7, n. 4, p. 259-266.

Viegas, C.J.; Bolzani, V.D.S.; Furlan, M.; Fraga, C.A.M.; Barreiro, E.J. 2004. Produtos naturais como candidatos a fármacos úteis no tratamento do mal de alzheimer. Química Nova, v. 27, n. 4, p. 655-660. 


\section{Chapter 4}

Chemical composition and antioxidant activity of the leaf essential oils from three Mentha species

Selene Maia de Morais

Alexandre Sousa Barros

Icaro Gusmão Pinto Vieira

Rita de Cássia Alves Pereira

Cleonilda Claita Carneiro Pinto and Hortencia Ribeiro Liberato

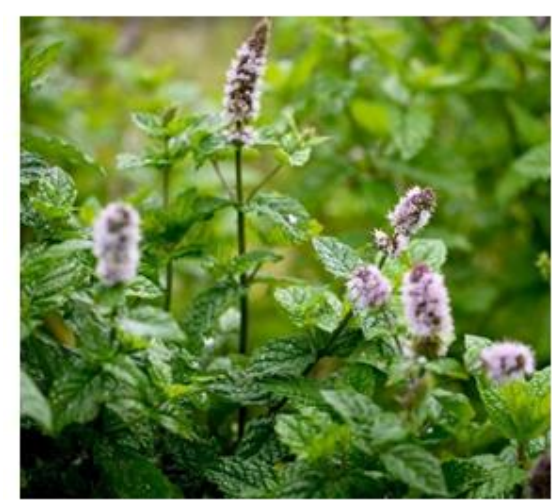

Mentha spicata<smiles>CCC1CC(C)CC[C@@H]1O</smiles>

Menthol<smiles>CC(C)=C1CC[C@@]2(C)O[C@H]2C1=O</smiles>

Piperitenone oxide

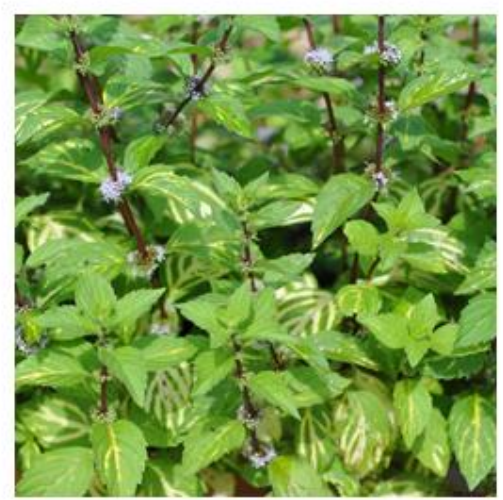

Mentha $\times$ gracilis

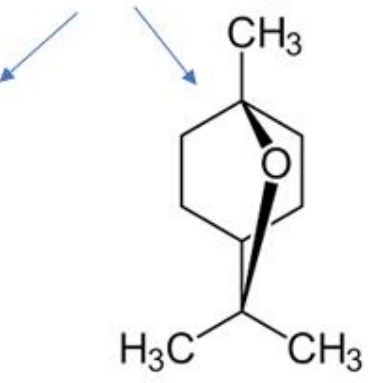

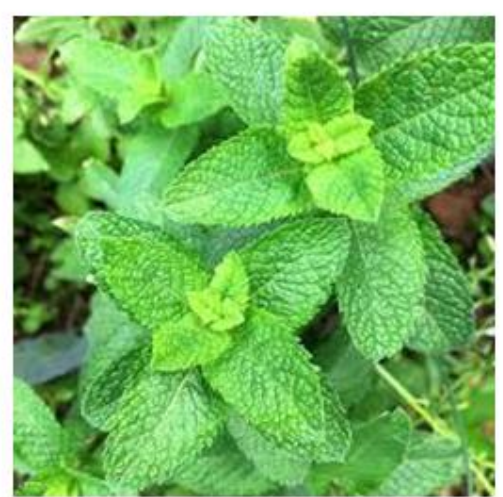

\section{Mentha villosa}

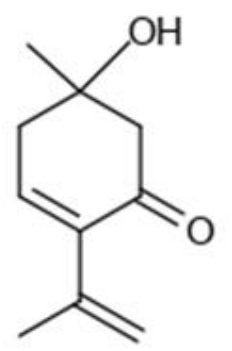




\section{INTRODUCTION}

The Lamiaceae family includes about 250 genera, represented by approximately 6,970 species has a wide range of species related to biological and pharmacological activities. The Lamiaceae family includes about 250 genera, represented by approximately 6,970 species has a wide range of species related to biological and pharmacological activities. Since ancient times, plants of the family have been used to improve the flavor and organoleptic properties of different types of food, and phytotherapy (Falcão; Menezes, 2003; Blumenthal, 1999; Bozin et al., 2006; Bruneton, 1999).

Among the genera of the family, the Mentha genus stands out for its therapeutic and industrial applications. Several species have distribution worldwide, with the center of origin to Southern Europe and the Mediterranean region, supporting low temperatures, but well adapted to the tropical climate. They are evergreen plants with opposite leaves, petiolated and pubescent. There are approximately 25 species in the genus, and the genus Mentha consists of a large number of hybrids mainly from the cross between the various populations, such as the $M . x$ villosa, hybrid of crossing $M$. spicata with $M$. suaveolens, as the M. $x$ gracilis, hybrid of crossing M. arvensis with M. spicata (Mattos, 2000; Hokkini, 1991; Tucker; Naczi, 2007; Zeinali et al., 2005; Turra; Pereira, 2012; Pegoraro et al., 2010).

The mint stands out for culinary use or medicinal teas to combat intestinal parasites and digestive disorders. The aromatic leaves of Mentha species are used fresh and dried as flavorings or spices in a wide variety of foods. They contain biologically active components. The main product of Mentha is essential oil, which can be obtained by different extraction methods. Essential oils are volatile organic constituents responsible for the fragrance of many plants. They can be obtained from flowers, leaves, fruits, seeds, roots, rhizomes and stems of plants. The essential oils may contain about 20 to 60 components in very different concentration and are characterized by two or three main components in relatively high concentrations compared to other components present (Lorenzi; Matos, 2002; Gracindo et al., 2006; Monteiro, 2009; Morais et al., 2006; Croteau; Kutchan; Lewis, 2000).

The main components found in the essential oil of Mentha are menthol, menthone, isomenthone, 1,8-cineole (eucalyptol), menthyl acetate, menthofuran, limonene, $\beta$ - 
myrcene, $\beta$-caryophyllene, pulegone, carvone, piperitone oxide, piperitenone oxide and linalool (Gracindo et al., 2006; Xu et al., 2003; Pittler; Ernst, 1998).

The essential oils of Mentha genus species arouse great interest due to their biological properties and their commercial value. Among the biological properties stand out its antioxidant activity, both in scavenging free radicals as in the inhibition of peroxidation of $\beta$-carotene (Mimica-Dukic et al., 2003; Schmidt et al., 2009).

Free radical is a chemical species with one or more unpaired electrons. Its excess has harmful effects such as peroxidation of membrane lipids and attack to proteins the tissues and membranes, DNA, enzymes and carbohydrates. The free radicals are related to a series of chronic diseases such as arteriosclerosis, cancer, inflammation and neurodegenerative diseases such as Parkinson's disease and Alzheimer's disease. An effective way to eliminate the free radicals is with the help of antioxidant compounds. Therefore it has focused attention on the use of antioxidants to protect the biological cells of damage caused by free radicals (Berger; Hamilton, 1995; Husain; Cillard; Cillard, 1987; Nickavar et al., 2006; Galvez et al., 2005; Kukic; Petrovic; Niketic, 2006; Kiselova et al., 2006; Mathew; Abraham, 2006).

Antioxidants have been widely used as food additives to provide protection against oxidative degradation of food and extend its useful life. They can act as free radical scavengers, reducing agents, chelating agents metal, deactivator of singlet oxygen molecules and/or activator of antioxidant defense enzymes to suppress radical damage in biological systems (Djeridane et al., 2006; Yu et al., 2002; Prior; Wu; Schaich, 2005).

Therefore, the aim of this study was to determine the chemical composition of essential oils and evaluate the potential antioxidant against the DPPH radical and to system $\beta$ carotene/linoleic acid of Mentha spicata L. (Botucatu Mint), Mentha sp. x Mentha villosa Huds. (Ceará, Brazil), Mentha x Mentha gracilis Sole. (Bergamot). 


\section{MATERIALS AND METHODS}

\subsection{PLANT MATERIAL AND EXTRACTION OF ESSENTIAL OILS}

The plant material was cultivated and collected in the morning at a farm of Embrapa Tropical Agroindustry (Ceará), located at the Federal University of Ceará (Fortaleza, Brazil). The three species have botanic and genetic certification and were obtained from the databank of germoplasm of Embrapa Genetic Products located in Brasília (Brazil). The essential oils were extracted at Padetec - Technology Development Park (Fortaleza, Brazil) by hydrodistillation as described in the literature (Craveiro; Matos; Alencar, 1976).

\subsection{ANALYSIS OF GAS CHROMATOGRAPHY / MASS SPECTROMETRY (GC-MS)}

The chemical analysis of the constituents of essential oils was performed by gas chromatography coupled with mass spectrometer in Shimadzu QP-2010 model using the following conditions: Column: DB-5 MS (Agilent, Part No. 122-5532); coated capillary column of fused silica $(30 \mathrm{~m} \times 0.25 \mathrm{~mm} \times 0.25 \mu \mathrm{m})$; Carrier gas: He, at a flow rate of $1 \mathrm{ml}$ / min at the constant linear velocity mode; injector temperature was $250^{\circ} \mathrm{C}$ in split mode $(1: 100)$ and the detector temperature was $250^{\circ} \mathrm{C}$. The column temperature was programmed from $35-180^{\circ} \mathrm{C}$ at $4^{\circ} \mathrm{C} / \mathrm{min}$, then $180-280^{\circ} \mathrm{C}$ at $17^{\circ} \mathrm{C} / \mathrm{min}$ and $280^{\circ} \mathrm{C}$ for $10 \mathrm{~min}$; and the mass spectra were obtained with electron impact of $70 \mathrm{eV}$. The injected sample volume was $1 \mathrm{ml}$. The compounds were identified by their retention index in gas chromatography compared to known compounds for the type of column used, and by comparison of their mass spectra with those present in the database of virtual library (NIST) and spectra published in the literature (Adams, 2001).

\subsection{NMR SPECTRA OF M. X M. VILLOSA ESSENTIAL OIL}

The chemical structure of the major compound of $M . x$. villosa essential oil was determined by one-dimensional spectroscopic methods $\left({ }^{1} \mathrm{H}\right.$ and $\left.{ }^{13} \mathrm{C} N M R\right)$ at the Northeastern Center for the Application and Use of Nuclear Magnetic Resonance (CENAUREM), located in Federal University of Ceará. 


\subsection{ANTIOXIDANT ACTIVITY}

\subsubsection{DETERMINATION OF ANTI-FREE RADICAL ACTIVITY BY DPPH DIPHENIL, 2-PICRYLHYDRAZYL) METHOD}

It was added to a test tube containing $3.9 \mathrm{ml}$ of DPPH methanolic solution $6.5 \times 10-5 \mathrm{M}$, $0.1 \mathrm{~mL}$ of methanolic solution of essential oils in different concentrations $(10000,5000$, $1000,500,100,50,5$ and $1 \mu \mathrm{g} / \mathrm{mL}$ ). Initially it was determined the absorbance of DPPH solution (control) and after $1.0 \mathrm{~h}$ the absorbance of the mixture was measured at 515 $\mathrm{nm}$ in spectrophotometer model Thermo-BioMate 5. The test was performed in triplicate and the results were considered positive if the absorbance decreased with time (Yepez et al., 2002). To calculate the potential for inhibition of DPPH for essential oils in terms of percentage (PI\%), the following equation was used.

$$
\mathrm{PI} \%=\frac{\mathrm{A}_{\mathrm{DPPH}}-\mathrm{A}_{\text {Sample }}}{\mathrm{A}_{\mathrm{DPPH}}} \times 100
$$

Where $A_{D P P H}$ is the absorbance of DPPH solution and $A_{\text {sample }}$ is the absorbance of the solution when the oil was added to a particular concentration.

The pecentual inhibition (\%) for each concentration was determined and the inhibitory concentration of $50 \%$ of the free radical DPPH $\left(\mathrm{IC}_{50}\right)$ was calculated by straight equation obtained by linear regression using Origin 7.0 statistical program. The data are presented with $95 \%$ confidence intervals.

\subsubsection{DETERMINATION OF ANTIOXIDANT CAPACITY - SYSTEM OF CO-OXIDATION OF B-CAROTENE/LINOLEIC ACID}

Initially $2 \mathrm{~mL} \beta$-carotene solution $(0.2 \mathrm{mg} / \mathrm{mL}$ chloroform $)$ was pipetted into a roundbottom flask containing $20 \mu \mathrm{L}$ linoleic acid and $200 \mu \mathrm{L}$ Tween 40 . The mixture was then evaporated at room temperature to remove chloroform. After evaporation, the mixture was immediately added to $100 \mathrm{~mL}$ of distilled water. The mixture was vigorously shaken to form an emulsion. Concentrations of 200, 100, 50, and $25 \mu \mathrm{g} / \mathrm{mL}$ of samples in methanol were prepared in test tubes and $0.2 \mathrm{~mL}$ aliquots were added to $5 \mathrm{~mL}$ of the solution of $\beta$-carotene - linoleic acid. A solution without the $\beta$-carotene - linoleic acid was prepared under the same conditions for each concentration (control solution). All the mixtures were incubated at $50{ }^{\circ} \mathrm{C}$ for 2 hours and measured at $470 \mathrm{~nm}$ (Wettasinghe; 
Shahidi, 1999) in spectrophotometer model Thermo-BioMate 5. Absorbance of the sample was measured immediately and the antioxidant activity (AA) was calculated based on the following equation.

$$
\mathrm{AA} \%=\left[1-\frac{\mathrm{A}_{\mathrm{t}}-\mathrm{A}_{0}}{\mathrm{~A}_{\mathrm{t}}^{\mathrm{o}}-\mathrm{A}_{0}^{\circ}}\right] \times 100
$$

Where $\mathrm{A}^{\mathrm{o}}{ }_{0}$ and $\mathrm{A}_{0}$ are the absorbance values measured at the initial time of the incubation for samples and control, respectively, while $\mathrm{A}^{\mathrm{o}_{t}}$ and $\mathrm{A}_{t}$ are the absorbance values measured in the samples or standards and control at $\mathrm{t}=2$ hours, respectively.

The antioxidant activity (\%) for each concentration was determined and the inhibitory concentration of $50 \%$ of the oxidation of $\beta$-carotene $\left(\mathrm{IC}_{50}\right)$ was calculated by straight equation obtained by linear regression using Origin 7.0 statistical program. The data are presented with $95 \%$ confidence intervals.

\section{RESULTS AND DISCUSSION}

The M. spicata, with $0.07 \%$ showed the best extraction yield of the essential oil from the studied species. The low yields obtained can be related to a number of factors such as the genotype, the plant developmental stage and environmental conditions (Marotti; Piccaglia; Giovanelli, 1994) essential oils extraction yields observed in the literature for some species of the genus range from 0.05 to $1.6 \%$ (Bhat et al., 2002). The yields of oils obtained are shown in Table 1.

Table 1. Extraction yields of Mentha essential oils

\begin{tabular}{|c|c|c|c|}
\hline Code & Precedence/Denomination & Name & \multicolumn{2}{c|}{ Yield \% } \\
\hline CM 22 & Bergamot & Mentha x gracilis Sole. & 0.04 \\
\hline CM 64 & Botucatu mint & Mentha spicata L. & 0.07 \\
\hline CM 65 & Ceará (Brazil) & Mentha sp. x M. villosa H. & 0.02 \\
\hline
\end{tabular}

The chemical composition of essential oils from M. x M. gracilis, M. spicata and M. $x$ M. villosa determined by gas chromatography coupled mass spectrometry is shown in Table 2. 
Table 2. Relative percentage composition of essential oils of Mentha species

\begin{tabular}{|c|c|c|c|c|c|}
\hline Compounds & $\mathrm{RI}_{\text {Lit. }}$ & $\mathrm{RI}_{\text {Exp. }}$ & $\begin{array}{l}\text { M. } x \text { gracilis } \\
\text { (Bergamot) }\end{array}$ & $\begin{array}{l}\text { M. spicata } \\
\text { (Botucatu) }\end{array}$ & $\begin{array}{l}\text { M. } x \text { villosa } \\
\text { (Ceará) }\end{array}$ \\
\hline 4-hydroxy-4-methylpentan-2-one & 839 & 895 & - & 0.58 & - \\
\hline$\alpha$-Pinene & 939 & 945 & 2.67 & 3.01 & 1.45 \\
\hline Sabinene & 975 & 973 & 2.75 & 3.62 & 1.36 \\
\hline$\beta$-Pinene & 980 & 979 & 9.10 & 5.70 & 2.01 \\
\hline Myrcene & 990 & 987 & 4.72 & 8.14 & 3.16 \\
\hline 3-Octanol & 994 & 994 & - & 0.17 & 0.33 \\
\hline Limonene & 1029 & 1022 & 2.53 & 14.29 & 6.38 \\
\hline 1,8-Cineole (eucalyptol) & 1031 & 1024 & 10.67 & 16.94 & 2.48 \\
\hline cis-Ocimene & 1040 & 1028 & 0.78 & 0.90 & 1.23 \\
\hline trans- $\beta$-Ocimene & 1044 & 1038 & - & 0.18 & - \\
\hline Terpinolene & 1085 & 1075 & - & 0.18 & - \\
\hline L-Linalool & 1099 & 1091 & - & 0.17 & - \\
\hline 3-Octanyl acetate & 1102 & 1110 & - & 0.10 & 0.51 \\
\hline Isomenthone & 1163 & 1153 & 0.74 & - & - \\
\hline Menthofurane & 1164 & 1154 & - & 2.31 & - \\
\hline 1-Menthol & 1175 & 1170 & 20.16 & - & - \\
\hline$\alpha$-Terpineol & 1188 & 1172 & - & 0.40 & - \\
\hline Pulegone & 1207 & 1229 & - & 1.89 & - \\
\hline D-Carvone & 1244 & 1247 & - & - & 1.01 \\
\hline cis-Piperitone oxide & 1254 & 1249 & - & - & 0.59 \\
\hline 1-Hydroxy-p-mentha-4,8-dien-3-one & - & 1362 & - & - & 42.79 \\
\hline Piperitenone oxide & 1363 & 1363 & 33.20 & 24.44 & 10.13 \\
\hline$\beta$-Bourbonene & 1388 & 1385 & - & 0.26 & 0.37 \\
\hline$\beta$-Elemene & 1391 & 1392 & - & - & 0.35 \\
\hline Trans- $\beta$-Caryophylene & 1418 & 1420 & 4.75 & 6.95 & 6.72 \\
\hline$\alpha$-Humulene & 1452 & 1457 & - & 0.36 & 0.62 \\
\hline$\beta$-Farnesene & 1457 & 1461 & - & 0.53 & 0.85 \\
\hline Epi-Bicyclosesquiphelandrene & 1471 & 1468 & & & 0.71 \\
\hline Germacrene D & 1485 & 1483 & 4.77 & 6.34 & 10.17 \\
\hline Y-elemene & 1492 & 1498 & 1.69 & 0.84 & - \\
\hline Bicyclogermacrene & 1494 & 1498 & - & - & 1.47 \\
\hline Germacrene A & 1503 & 1509 & - & - & 0.32 \\
\hline 1S,Cis-Calamenene & 1521 & 1522 & - & - & 0.58 \\
\hline Spathulenol & 1578 & 1576 & - & - & 0.64 \\
\hline Caryophylene oxide & 1581 & 1580 & - & 0.23 & 0.63 \\
\hline Phytol & 1949 & 1838 & - & 0.18 & - \\
\hline \multicolumn{2}{|l|}{ Monoterpene hydrocarbons } & & 22.55 & 36.02 & 15.59 \\
\hline \multicolumn{2}{|l|}{ Oxygenated monoterpenes } & & 64.77 & 46.25 & 57.51 \\
\hline \multicolumn{2}{|l|}{ Sesquiterpene hydrocarbons } & & 11.21 & 15.28 & 22.16 \\
\hline \multicolumn{2}{|l|}{ Oxygenated sesquiterpenes } & & - & 0.23 & 1.27 \\
\hline \multicolumn{2}{|l|}{ Others } & & - & 0.93 & 0.33 \\
\hline \multicolumn{2}{|l|}{ \% Total Identified } & & 98.53 & 98.71 & 96.86 \\
\hline
\end{tabular}

RILit.- Retention Index of Literature; RIExp.- Experimental Retention Index. 
From the GC/MS analysis 13 components were identified in the essential oil of $M . x$ gracilis, 25 components for the M. spicata and also 25 for M. $x$ villosa. The percentage of compounds identified in the essential oils of the three species ranged from 96.86 to 98.71\% and a predominance of oxygenated monoterpenes was observed in the composition of the essential oils, as reported in literature (Pegoraro et al., 2010; Gracindo et al., 2006). A significant content of hydrocarbon monoterpenes was observed in the essential oil of M. spicata.

The essential oil of M. $x$ gracilis presented the predominance of monoterpenes piperitenone oxide, menthol, 1,8-cineole (eucalyptol) and $\beta$-pinene (9.10\%). Different results were reported with high carvone contents followed in smaller proportion by limonene (Poovaiah; Weller; Jenks, 2006; Zheljazkov; Astatkie, 2011).

The essential oil of M. spicata presented as major constituents the monoterpenes piperitenone oxide, 1,8-cineole, eucalyptol, limonene and myrcene. Considerable levels of trans- $\beta$-caryophyllene and germacrene $\mathrm{D}$ were also found. The oil composition of $M$. spicata is described as rich in carvone, which was not observed in this work (Gracindo et al., 2006; Poovaiah; Weller; Jenks, 2006).

The CG/MS analysis of the essential oil of $M x$ villosa showed two compounds with similar mass spectra (Figure 4.1 ) with base peak $M^{+} 166$, and differences only related to peaks height, one correspondent to piperitenone oxide (10.13\%) and the other one was the major component (42.79\%).

Figure 4.1. Mass spectra of the major component from $M x$ villosa EO and Piperitenone oxide compared to literature data (Adams, 2007).

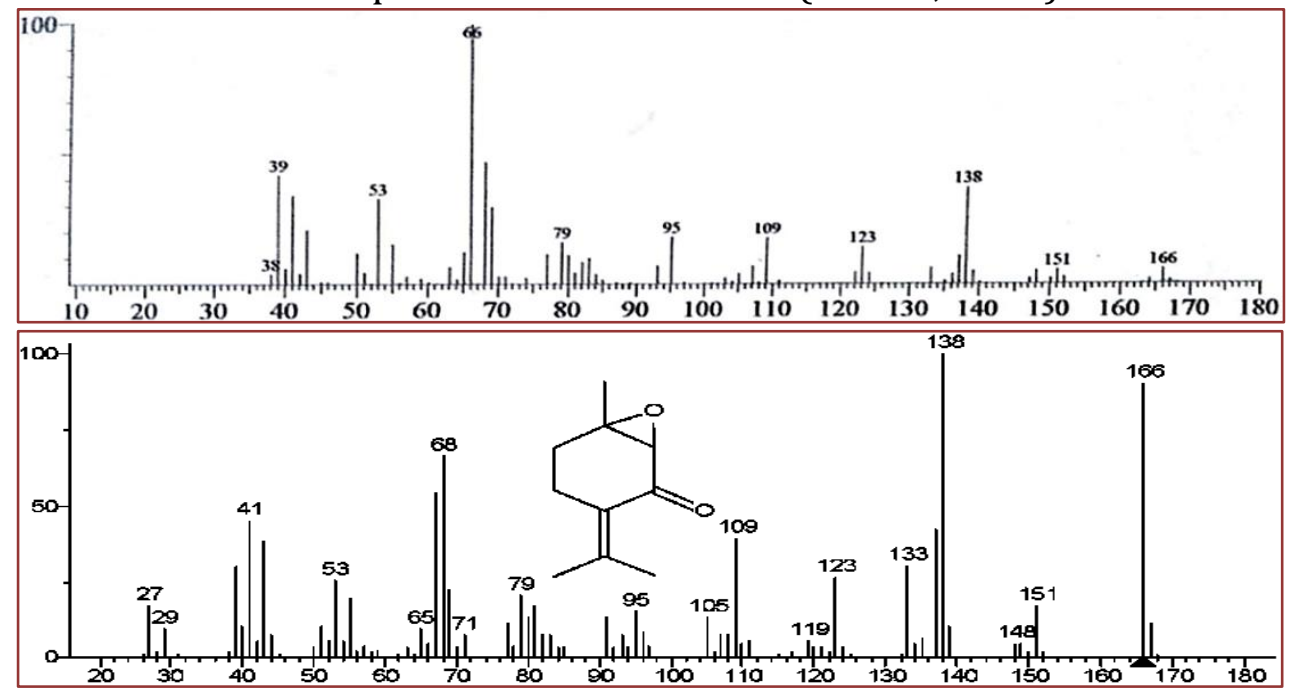


${ }^{13} \mathrm{C}$ NMR spectra of hole essential oil show two carbonyl groups in 212 an 199 (the monoterpenes 1-hydroxy-p-mentha-4,8-dien-3-one, piperitenone oxide and limonene (6.38\%). The sesquiterpene germacrene D also stood out with the content of $10.17 \%$. High levels of piperitenone oxide and limonene are also found for the essential oil of $M . x$ villosa (Matos-Rocha et al., 2013; Lima et al., 2014). Figure 4.2 shows the proposed structure of major component, 1-hydroxy-p-mentha-4,8-dien-3-one, oxygenated monoterpene also identified by nuclear magnetic resonance ${ }^{1} \mathrm{H}$ and ${ }^{13} \mathrm{C}$ as shown in table 3.

Figure 4.2. Representation of structural formula of 1-hydroxy-p-mentha-4,8-dien-3-one and piperitenone oxide

1-hydroxy-p-mentha-4,8-dien-3-one

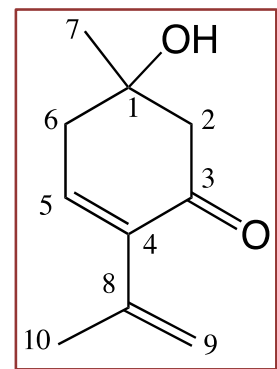

Piperitenone oxide

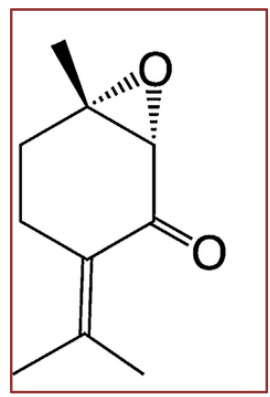

Table 3. Chemical shifts of ${ }^{1} \mathrm{H}$ and ${ }^{13} \mathrm{C}$ for 1 -hydroxy-p-mentha-4,8-dien-3-one

\begin{tabular}{|c|c|c|c|c|}
\hline $\begin{array}{l}\text { Carbon } \\
\text { Number }\end{array}$ & $\begin{array}{c}\delta \mathrm{H} \\
(\text { predicted })\end{array}$ & $\begin{array}{l}\delta \mathrm{H} \\
\text { real }\end{array}$ & $\begin{array}{c}\delta \mathrm{C} \\
\text { (predicted) }\end{array}$ & $\begin{array}{l}\delta \mathrm{C} \\
\text { real }\end{array}$ \\
\hline 1 & - & - & 71.06 & 71.35 \\
\hline 2 & $2.45 ; 2.64$ & $2.55 ; 2.62$ & 46.45 & 44.96 \\
\hline 3 & - & & 195.35 & 199.91 \\
\hline 4 & - & & 133.37 & 133.92 \\
\hline 5 & 6.45 & & 126.02 & 120.85 \\
\hline 6 & $2.34 ; 2.38$ & $2.35 ; 2.40$ & 39.19 & 36.29 \\
\hline 7 & 1.31 & & 27.98 & 28.13 \\
\hline 8 & - & & 138.20 & 135.67 \\
\hline 9 & $5.35 ; 5.01$ & $5.40(\mathrm{~m})$ & 112.48 & 109.81 \\
\hline 10 & 1.84 & & 21.57 & 20.70 \\
\hline
\end{tabular}

The predicted chemical shifts were obtained through software available in http://www.nmrdb.org 
The fragmentations of the main peaks in the mass spectrum of the majoritary monoterpene in the essential oil of M. x villosa are shown in figure 4.3.

Figure 4.3. Suggested fragmentations for the main peaks in 1-hydroxy- $p$-mentha-4,8dien-3-one

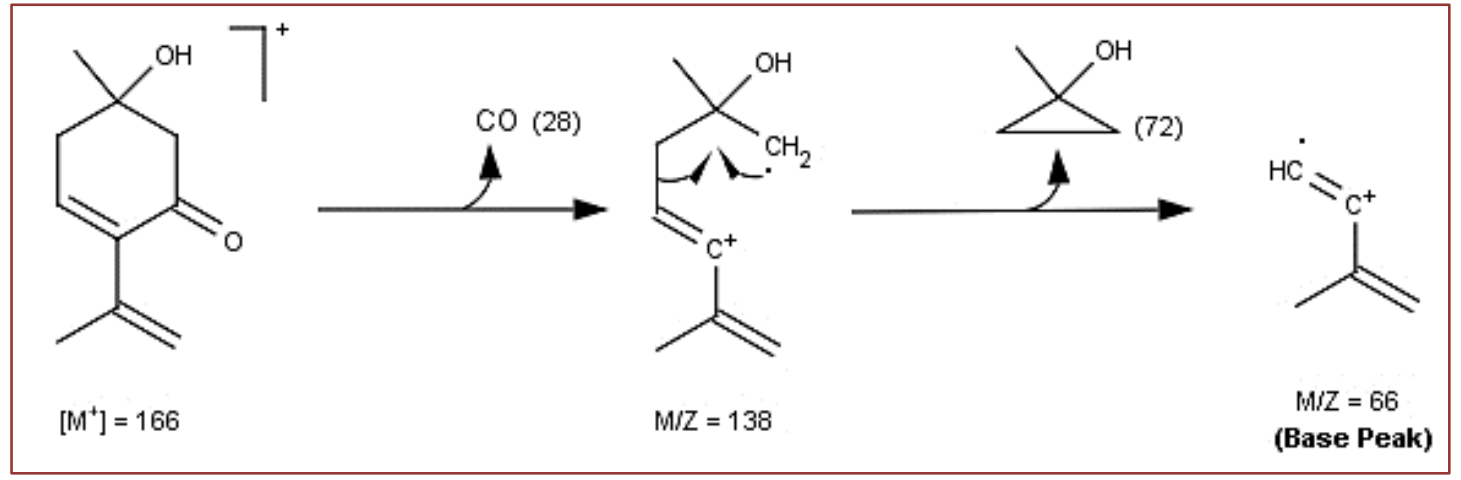

The stable radical DPPH was reduced by the methanol extract of thymol with an $\mathrm{IC}_{50}$ value of $0.538 \pm 0.02 \mu \mathrm{g} / \mathrm{mL}$ (Esmaeili \& Mohabi, 2014). By the $\beta$-carotene/linoleic acid method, among standards tested, BHT ( $\mathrm{IC}_{50}>25 \mu \mathrm{g} / \mathrm{mL}$ ) was the most efficient, followed by thymol (IC $50105.82 \mu \mathrm{g} / \mathrm{mL}$ ) and ascorbic acid (IC $50118.15 \mu \mathrm{g} / \mathrm{mL}$ ) (Andrade et al., 2013).

The essential oil of $M$. spicata stood out from the others for its antioxidant activity, with $\mathrm{IC}_{50}$ of $27.54 \mu \mathrm{g} / \mathrm{mL}$ for the scavenging method of $\mathrm{DPPH}^{*}$ and $0.44 \mathrm{mg} / \mathrm{mL}$ by the method of inhibiting the oxidation of $\beta$-carotene. The $\mathrm{IC}_{50}$ value of this oil by the method of inhibition of oxidation of $\beta$-carotene was near to thymol $(0.33 \mathrm{mg} / \mathrm{mL})$, demonstrating that the high limonene content can contribute to the antioxidant activity (Gracindo et al., 2006).

In general, the phenolic compounds present in essential oils such as thymol and carvacrol have higher antioxidant activity, nevertheless, in the essential oil of M. spicata unsaturated hydrocarbons are in higher proportion. Besides the oxygenated monoterpenes as phenolic compounds, the allylic alcohols as 1,8-cineole and unsaturated terpene hydrocarbons as limonene and myrcene also have significant activity (Ruberto; Baratta, 2000).

Wang et al. (2019) determine the efficacy of seven predominant wine terpenoids (i.e. $\alpha$ pinene, limonene, myrcene, geraniol, linalool, nerol, and terpineol) as antioxidant by 
DPPH method. $\alpha$-Pinene showed the strongest DPPH free radical scavenging effect with an $\mathrm{IC}_{50}=2.57 \pm 0.18 \mathrm{mg} / \mathrm{mL}$. This was followed by limonene at $13.35 \pm 0.26 \mathrm{mg} / \mathrm{mL}$ and nerol at $26.08 \pm 2.28 \mathrm{mg} / \mathrm{mL}$. Myrcene $(40.83 \pm 1.68 \mathrm{mg} / \mathrm{mL})$ showed the lowest scavenging activity. The determined IC $_{50}$ values were in the order BHT $<\alpha$-pinene $<$ limonene $<$ nerol < terpineol < geraniol < linalool < myrcene. Then mainly limonene followed by myrcene can contribute to the antioxidant activity.

Table 4. Assays of antioxidant activity of essential oils of Mentha species

\begin{tabular}{|c|c|c|}
\hline \multirow[b]{2}{*}{ Mentha specie } & \multicolumn{2}{|r|}{$\mathrm{IC}_{50}$} \\
\hline & DPPH $(\mu \mathrm{g} / \mathrm{mL})$ & $\begin{array}{c}\beta \text {-Carotene /linoleic acid } \\
(\mathrm{mg} / \mathrm{mL})\end{array}$ \\
\hline Mentha $\times$ gracilis & $93.44 \pm 0.08$ & $0.83 \pm 0.04$ \\
\hline Mentha spicata & $27.54 \pm 0.01$ & $0.44 \pm 0.02$ \\
\hline Mentha $x$ villosa & $111.78 \pm 0.10$ & $1.98 \pm 0.07$ \\
\hline Thymol & $1.12 \pm 0.02$ & $0.33 \pm 0.04$ \\
\hline
\end{tabular}

It is known that the $\pi$ bonds are responsible for the antioxidant activity of terpenes. Blocking the double bond decreases the antioxidant activity of monoterpenes (Wojtunik; Ciesla; Waksmundzka-Hajnos, 2014).

\section{CONCLUSIONS}

The composition of essential oils showed the major presence of oxygenated monoterpenes. The monoterpenes piperitenone oxide, limonene, 1,8-cineole (eucalyptol), myrcene and pinene were found in relevant content in the evaluated essential oils, as well as the sesquiterpenes trans- $\beta$-caryophyllene and germacrene D. Menthol and 1-hydroxy-p-mentha-4,8-dien-3-one were also prevalent in the essential oils from M. x gracilis and M. x villosa, respectively.

The essential oils from M. $x$ villosa and M. $x$ gracilis presented, in general, lower antioxidant activity when compared to thymol. The essential oil of $M$. spicata exhibited better antioxidant activity among the studied species and its inhibitory action of $\beta$ carotene oxidation can be considered similar to thymol activity, probably due to higher content in limonene and 1,8-cineole. Also it was possible to identify by means of mass spectrum and ${ }^{1} \mathrm{H}$ and ${ }^{13} \mathrm{C}$ NMR, a substance which was not yet reported in the literature, 
the 1-hydroxy-p-mentha-4,8-dien-3-one, an oxygenated monoterpene and a piperitenone oxide isomer.

\section{REFERENCES}

Adams, R.P. Identification of essential oil components by Gas Chromatography Quadrupole Mass Spectroscopy. USA, Allured Publishing Corporation, 2001.

Andrade, M.A.; das Graças Cardoso, M.; de Andrade, J.; Silva, L.F.; Teixeira, M.L.; Valério Resende, J.M.; da Silva Figueiredo, A.C.; Barroso, J.G. Chemical Composition and Antioxidant Activity of Essential Oils from Cinnamodendron dinisii Schwacke and Siparuna guianensis Aublet. Antioxidants (Basel, Switzerland), 2(4), 384-397, 2013.

Araújo, C. S.; de Oliveira, A. P.; Lima, R. N.; Alves, P. B.; Diniz, T. C.; Almeida, J. R. G. S. Chemical constituents and antioxidant activity of the essential oil from leaves of Annona vepretorum Mart. (Annonaceae). Pharmacognosy magazine, v. 11, n. 43, p. 615, 2015.

Berger, K. G.; Hamilton, R. J. Developments in Oils and Fats, London: Chapman \& Hall. (1995), cap. 7.

Bhat, S.; Maheshwari, P.; Kumar, S.; Kumar, A. Mentha species: in vitro regeneration and genetic transformation. Molecular Biology Today, v. 3, n. 1, p. 11-23, 2002.

Blumenthal, M. The complete German commission E monographs. Therapeutic Guide to Herbal Medicines. American Botanical Council: Austin, Texas, 1999.

Bozin, B.; Mimica-Dukic, N.; Simin, N.; Anackov, G. Characterization of the volatile composition of essential oils of some Lamiaceae spices and the antimicrobial and antioxidant activities of the entire oils. Journal of agricultural and food chemistry, v. 54, n. 5, p. 1822-1828, 2006.

Bruneton, J. Pharmacognosy, Phytochemistry, Medicinal Plants, 2nd ed.; Intercept Ltd.: London, New York, 1999.

Craveiro, A. A.; Matos F. J.; Alencar J. W. A simple and inexpensive steam generator for essential oils extraction. Journal of Chemical Education, v. 53, n. 10, p. 652, 1976.

Croteau R.; Kutchan, T.M.; Lewis, N.G., Biochemistry \& Molecular Biology of Plants, American Society of Plant Physiologists, 2000, cap. 24.

Djeridane, A.; Yousfi, M.; Nadjemi, B.; Boutassouna, D.; Stocker, P.; Vidal, N. Antioxidant activity of some Algerian medicinal plant extracts containing phenolic compounds. Food chemistry, v. 97, n. 4, p. 654-660, 2006.

Esmaeili, A; Mohabi, N. Experimental and Theoretical Determination of the Antioxidant Properties of Aromatic Monoterpenes of Thymol and 2,5,6-Trifluorothymol, International Journal of Food Properties, 17:5, 1162-1168, 2014.

Falcão, D. Q.; Menezes, F. S. Revisão etnofarmacológica, farmacológica e química do gênero Hyptis. Revista Brasileira de Farmacognosia, v. 84, n. 3, p. 69-74, 2003.

Galvez, M.; Martin-Cordero, C.; Houghton, P. J.; Ayuso, M. J. Antioxidant activity of methanol extracts obtained from Plantago species. Journal of Agricultural and Food Chemistry, v. 53, n. 6, p. 1927-1933, 2005.

Gracindo, L. A. M. B.; Grisi, M. C. M.; Silva, D. B.; Alves, R. B. N.; Bizzo, H. R.; Vieira, R. F. Chemical characterization of mint (Mentha spp.) germplasm at Federal District, Brazil. Revista Brasileira de Plantas Medicinais-Botucatu, v. 8, p. 5-9, 2006.

Husain, S. R.; Cillard. J.; Cillard, P. Hydroxyl radical scavenging activity of flavonoids. Phytochemistry, v. 26, n. 9, p. 2489-2491, 1987.

Kiselova, Y.; Ivanova, D.; Chervenkov, T.; Gerova, D.; Galunska, B.; Yankova, T. Correlation between the in vitro antioxidant activity and polyphenol content of aqueous extracts from Bulgarian herbs. Phytotherapy Research: An International Journal Devoted to Pharmacological and Toxicological Evaluation of Natural Product Derivatives, v. 20, n. 11, p. 961-965, 2006. 
Kokkini, S. Chemical races within the genus Mentha L. In: Essential oils and waxes. Springer, Berlin, Heidelberg, p. 63-78, 1991.

Kukic, J.; Petrovic, S.; Niketic, M. Antioxidant activity of four endemic Stachys taxa. Biological and Pharmaceutical Bulletin, v. 29, n. 4, p. 725-729, 2006.

Lima, T. C.; Silva, T. K. M.; Silva, F. L.; Barbosa-Filho, J. M.; Marques, M. O. M.; Santos, R. L. C.; Sousa, D. P. Larvicidal activity of Mentha $x$ villosa Hudson essential oil, rotundifolone and derivatives. Chemosphere, v. 104, p. 37-43, 2014.

Lorenzi, H.; Matos, F. J. A. Plantas medicinais no Brasil: nativas e exóticas cultivadas. Nova Odessa, SP: Instituto Plantarum, 2002.

Melo, G.F.A.; Costa, A.C.V.; Garino Junior, F.; Medeiros, R.S.; Madruga, M.S.; Queiroga Neto, V. The sensitivity of bacterial foodborne pathogens to Croton blanchetianus Baill essential oil. Brazilian Journal of Microbiology, v. 44, n. 4, p. 1189-1194, 2013.

Marotti M.; Piccaglia, R.; Giovanelli, E.; Deans, S. G.; Eaglesham, E. Effects of planting time and mineral fertilization on peppermint (Mentha $x$ piperita L.) essential oil composition and its biological activity. Flavour and Fragrance journal, v. 9, n. 3, p. 125-129, 1994.

Mathew, S.; Abraham, T. E. In vitro antioxidant activity and scavenging effects of Cinnamomum verum leaf extract assayed by different methodologies. Food and Chemical Toxicology, v. 44, n. 2, p. 198-206, 2006.

Matos-Rocha, T. J.; Cavalcanti, M. G. S.; Barbosa-Filho, J. M.; Lúcio, A. S. S. C.; Veras, D. L.; Feitosa, A. P. S.; Siqueira Júnior, J. P.; Almeida, R. N.; Marques, M. O. M.; Alves, L. C.; Brayner, F. A. In vitro evaluation of schistosomicidal activity of essential oil of Mentha $x$ villosa and some of its chemical constituents in adult worms of Schistosoma mansoni. Planta medica, v. 79, n. 14, p. 1307-1312, 2013.

Mattos, S. H. Estudos fitotécnicos da Mentha arvensis L. var. piperacens Holmes como produtora de mentol no Ceará.Tese de doutorado, Universidade Federal do Ceará, Fortaleza, 2000.

Mimica-Dukic, N.; Bozin, B.; Sokovic, M.; Mihajlovic, B.; Matavulj, M. Antimicrobial and antioxidant activities of three Mentha species essential oils. Planta medica, v. 69, n. 05, p. 413-419, 2003.

Monteiro, R. Desenvolvimento de menta e produção de óleo essencial sob diferentes condições de manejo. Dissertação de Mestrado, Universidade Federal do Paraná, Brasil, 2009.

Morais, S. M.; Catunda, F. E. A.; Silva, A. R. A.; Neto, J. M.; Rondina, D.; Cardoso, J. H. L. Atividade antioxidante de óleos essenciais de espécies de Croton do nordeste do Brasil. Química Nova, v. 29, n. 5, p. 907-910, 2006.

Nickavar, B.; Kamalinejad, M.; Haj-Yahya, M.; Shafaghi, B. Comparison of the free radical scavenging activity of six iranian achillea. species. Pharmaceutical biology, v. 44, n. 3, p. 208-212, 2006.

Pegoraro, R. L.; Falkenberg, M. B.; Voltolini, C. H.; Santos, M.; Paulilo, M.T.S. Produção de óleos essenciais em plantas de Mentha x piperita L. var. piperita (Lamiaceae) submetidas a diferentes níveis de luz e nutrição do substrato. Brazilian Journal of Botany, v. 33, n. 4, p. 631-637, 2010.

Pittler, M. H.; Ernst, E. Peppermint oil for irritable bowel syndrome: a critical review and metaanalysis. The American journal of gastroenterology, v. 93, n. 7, p. 1131-1135, 1998.

Poovaiah, C. R.; Weller, S. C.; Jenks, M. A. Adventitious shoot regeneration of scotch spearmint (menthe $x$ gracilis Sole). In Vitro Cellular \& Developmental Biology-Plant. v. 42, n. 4, p. 354-358, 2006.

Prior, R.L.; Wu, X.; Schaich, K. Standardized methods for the determination of antioxidant capacity and phenolics in foods and dietary supplements. Journal of agricultural and food chemistry, v. 53, n. 10, p. 4290-4302, 2005.

Ruberto, G.; Baratta, M. T. Antioxidant activity of selected essential oil components in two lipid model systems. Food chemistry, v. 69, n. 2, p. 167-174, 2000.

Schmidt, E.; Bail, S.; Buchbauer, G.; Stoilova, I.; Atanasova, T.; Stoyanova, A.; Krastanov, A.; Jirovetz, L. Chemical composition, olfactory evaluation and antioxidant effects of essential oil from Mentha $x$ piperita. Natural product communications, v. 4, n. 8, p. 1934578X0900400819, 2009.

Silva, A.B.; Oliveira, C.R.F.; Matos, C.H.C.; Santos, P.É.M.; Lira, C.R.I.M. Bioatividade do óleo essencial de Croton blanchetianus Baill (Euphorbiaceae) sobre Callosobruchus maculatus Fabricius, 1775 (Coleoptera: Chrysomelidae). Nativa, Sinop, v. 8, n. 4, p. 450-455, jul./ago. 2020. 
Tucker, A. O.; Naczi, R. F. C. Mentha: an overview of its classification and relationships. In: LAWRENCE, B. M (ed.). Mint: the genus Mentha. Boca Raton: CRC, 2007.

Turra, H. Z.; Pereira, P. B. Reclassificação taxonômica de acessos da coleção de Mentha spp da universidade de Brasília. Trabalho de conclusão de curso (Graduação) - Faculdade de Agronomia e Medicina Veterinária da Universidade de Brasília, Brasil, 2012.

Wettasinghe, M.; Shahidi, F. J. Evening primrose meal: a source of natural antioxidants and scavenger of hydrogen peroxide and oxygen-derived free radicals. Journal of Agricultural and Food Chemistry, v. 47, n. 5, p. 1801-1812, 1999.

Wojtunik, K. A.; Ciesla, L. M.; Waksmundzka-Hajnos, M. Model studies on the antioxidant activity of common terpenoid constituents of essential oils by means of the 2, 2-diphenyl-1-picrylhydrazyl method. Journal of agricultural and food chemistry, v. 62, n. 37, p. 9088-9094, 2014.

Xu, P.; Jia, W.; Bi, L.; Liu, X.; Zhao, Y. Studies components and quality of essential oil from Mentha piperita L. produced in Xinjiang, China. Chemistry and Industty of Forest Products, v. 23, p. 43-45, 2003.

Yepez, B.; Espinosa, M.; López, S.; Bolaños, G. Producing antioxidant fractions from herbaceous matrices by supercritical fluid extraction. Fluid Phase Equilibria, v. 194, p. 879-884, 2002.

Yu, L.; Perret, J.; Davy, B.; Wilson, J.; Melby, C. L. Antioxidant properties of cereal products. Journal of Food Science, v. 67, n. 7, p. 2600-2603, 2002.

Zeinali, H.; Arzani, A.; Razmjoo, K.; Rezaee, M. B. Evaluation of oil compositions of Iranian mints (Mentha ssp.). Journal of Essential Oil Research. V. 17, n. 2, 2005.

Zheljazkov, V. D.; Astatkie, T. Effect of residual distillation water of 15 plants and three plant hormones on Scotch spearmint (Mentha X gracilis Sole). Industrial Crops and Products, v. 33, n. 3, p. 704-709, 2011. 


\section{Chapter 5}

Applications of essential oils

Selene Maia de Morais
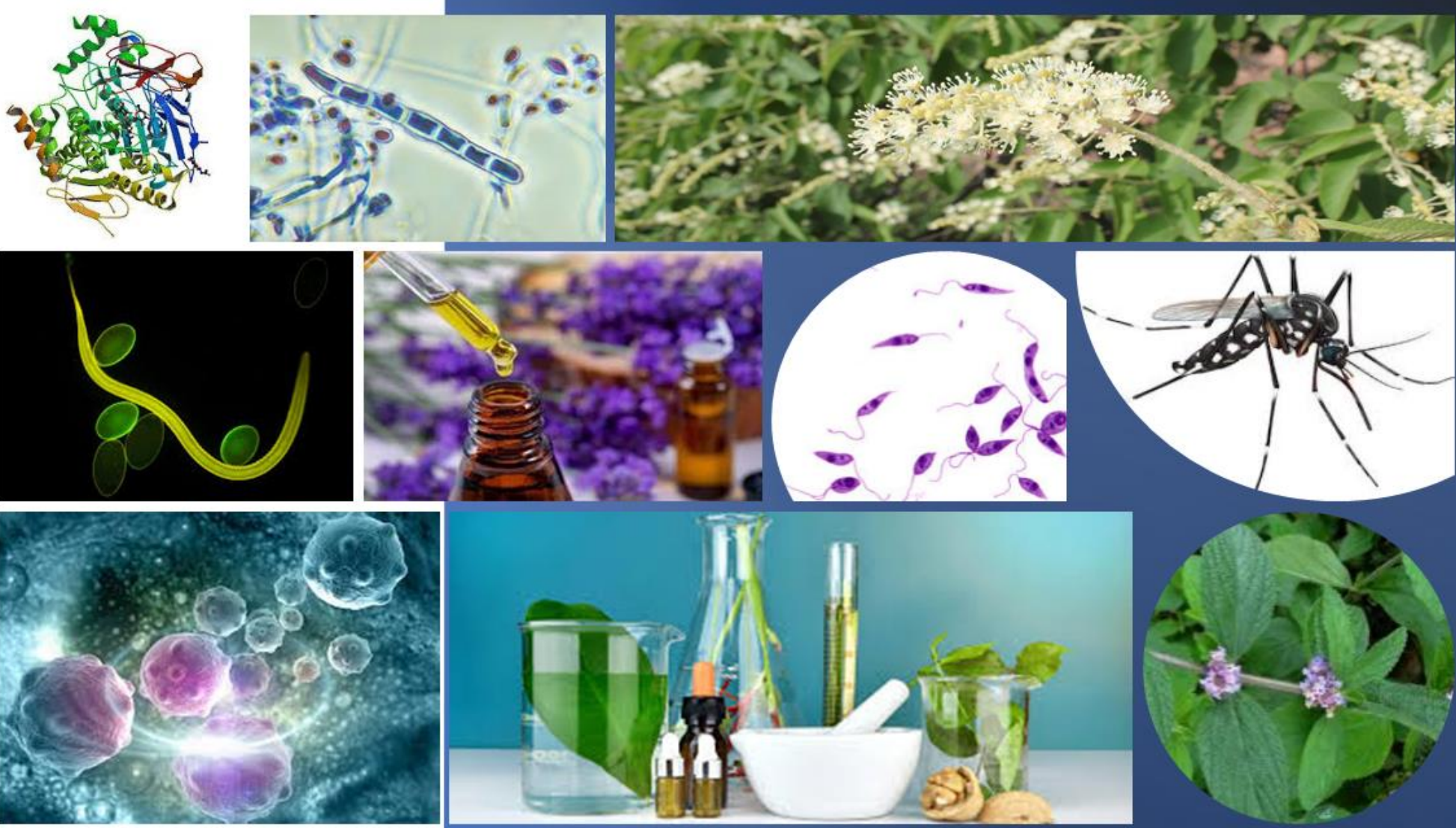


\section{INTRODUCTION}

The use of natural products as raw material for the extraction of chemical components that have biological activity has been widely reported over the years. The biodiversity of Brazil is considered a source of biologically active substances; therefore, its preservation and study are essential due to its enormous potential in the discovery of new drugs with pharmacological action, which has long been attracting interest from researchers in the pharmaceutical area (KORDALI et al., 2008).

Important active principles can be found in all parts of the plants, and these are synthesized by the secondary metabolism of plants giving rise to a series of known substances and with diverse biotechnological applications. One of the most important classes are the essential oils, which are volatile compounds released by some plants that have the function of chemical signaling for communication between species, protection against microorganisms, herbivores and environmental conditions (Nunes et al 2006). Essential oils are a rich source of volatile secondary metabolites, usually associated with important biological activities (Figure 5.1).

Figure 5.1. Some applications of essential oils from plants

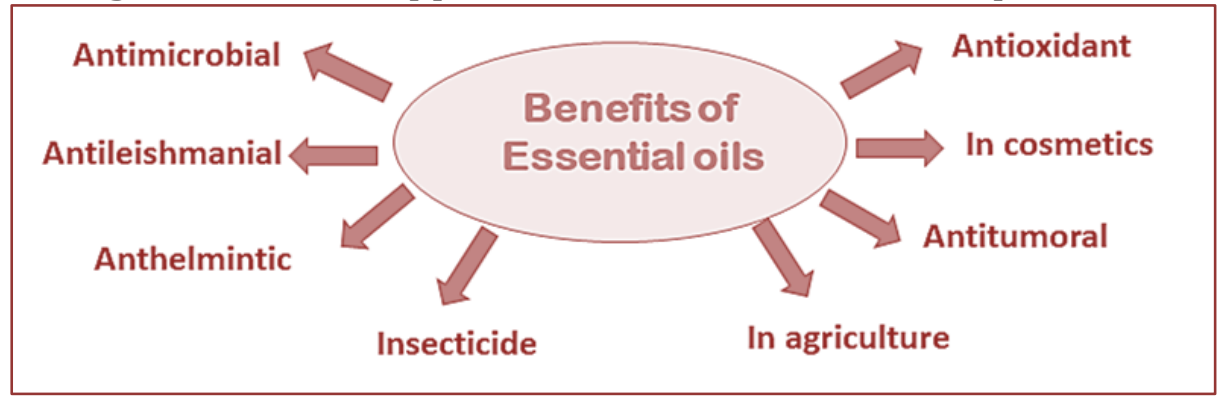

\subsection{AS ANTIMICROBIAL AGENT}

In modern complementary and alternative medical practice, plants are the primary source of therapeutics and each part of the plant, including the seeds, root, stem, leaves, and fruit, potentially contains bioactive components. The main bioactive components in medicinal plants are considered to be combinations of secondary metabolites

The interest in essential oils and their application in food preservation has been amplified in recent years by an increasingly negative consumer perception of synthetic preservatives. The antimicrobial activity of most terpenoids is linked to their functional 
groups, and it has been shown that the hydroxyl group of phenolic terpenoids and the presence of delocalized electrons are important for antimicrobial activity.

The terpenoids are a large group of antimicrobial compounds that are active against a broad spectrum of microorganisms, with the most active monoterpenoids identified so far being carvacrol and thymol. Dorman and Deans (2000) investigated the effect of many terpenoids against 25 different bacterial strains, and showed that all aromatic terpenoid compounds, except borneol and carvacrol methyl ester, exhibited a broad antimicrobial activity. The antimicrobial activity of carvacrol, thymol, linalool, and menthol were evaluated against Listeria monocytogenes, Enterobacter aerogenes, E. coli, and Pseudomonas aeruginosa. The most active compound was carvacrol followed by thymol with their highest MIC being 300 and $800 \mu \mathrm{g} / \mathrm{mL}$, respectively (Bassolé et al., 2010). Then these aromatic monoterpenes represent antimicrobial agents to be used in food preservation or for general antimicrobial use (Morten; Tina; Rikke et al., 2012)

Vitex gardneriana, popularly known as "jaramataia", is a shrub commonly found in the Caatinga biome located in northeast Brazil. In folk medicine, its leaves have been used as analgesic and anti-inflammatory agents. The chemical composition of the leaf essential oils extracted at 8.00, 12.00 and 17.00 h from $V$. gardneriana present a circadian rhythm, and antimicrobial and anticholinesterase activities vary with the composition. The main constituents were the sesquiterpenes cis-calamenene, 6,9-guaiadiene and caryophyllene oxide. The essential oils showed activity against strains of Trichophyton rubrum (Pereira et al., 2018).

The compounds thymol, eugenol, estragole and anethole and some $O$-methyl-derivatives (methylthymol and methyleugenol), whose structures are shown in figure 5.2, were tested against Candida spp. and Microsporum canis with and showed in vitro antifungal activities (Fontenelle et al., 2011). 
Figure 5.2. Antifungal aromatic monoterpenes and aryl-propanoids

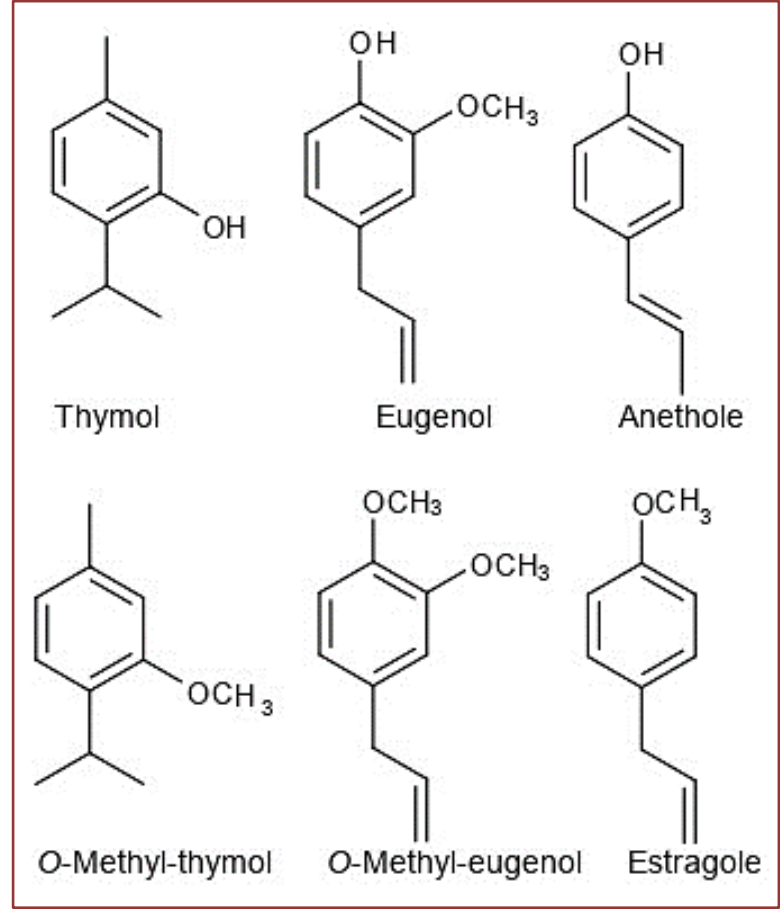

With the increase of microbial diseases and many reports of resistance of microorganisms to antifungal drugs, the importance of studies on bioprospecting of natural products with antimicrobial properties also increases. Essential oils from five Brazilian Ocimum species: O. americanum, O. basilicum var. purpurascens, 0 . basilicum var. minimum, 0 . micranthum and $O$. selloi were tested against Candida albicans, $C$. tropicalis, C. parapsilosis, C. glabrata and C. krusei by the broth microdilution method. The main constituents for 0 . americanum oil were 1,8-cineole (25.9\%) and (Z)-methyl cinnamate (29.4\%), for 0 . basilicum var. purpurascens linalool (41.5\%) and $\alpha$-muurulol (11.8\%), for O. basilicum var. minimum linalool (44\%) and 1,8-cineole (15.5\%), for 0 . micranthum and eugenol (64.11\%) and $\beta$-caryophyllene (14.3\%) and for 0 . selloi, linalool (16.8\%) and anethole (52.2\%). The Ocimum essential oils, mainly O. micranthum and $O$. selloi are active in vitro against the Candida species showing to be promising sources for new phytotherapeutic agents to treat mycosis due to the presence of effective antifungal compounds as eugenol and anethole (Vieira et al., 2014).

The essential oil from Coriandrum sativum L. fruits, obtained by hydro-distillation, was analyzed by gas chromatography/mass spectroscopy. Linalool was the main constituent (58.22\%). The oil was considered bioactive, showing an $\mathrm{LC}_{50}$ value of $23 \mu \mathrm{g} / \mathrm{mL}$ in the Artemia salina lethality test. The antifungal activity was evaluated against Microsporum 
canis and Candida spp. C. sativum essential oil is active in vitro against M. canis and Candida spp. demonstrating good antifungal activity (Soares et al., 2012).

Resistance to use antifungal drugs is a great concern seeking for scientists to discover new products to treat fungal infections. Essential oils and extracts of Plectranthus grandis and Plectranthus ornatus were tested against Trichophyton rubrum and Microsporum canis dermatophytes strains. Extracts were obtained from leaves by maceration in ethanol (96\%) during 7 days. The oils were obtained by hydrodistillation and analyzed by gas chromatography/mass spectrometry. A total of 25 components were identified, as major constituents the sesquiterpenes $\beta$-caryophyllene, $\alpha$-copaene, germacrene, $\beta$-caryophyllene and caryophyllene oxide. The decocts obtained from the extraction of essential oil presented a greater antioxidant action when compared with the essential oils, with $\mathrm{IC}_{50}$ values of $12.35 \mu \mathrm{g} / \mathrm{mL}$ and $15.69 \mu \mathrm{g} / \mathrm{mL}$ to $P$. ornatus and $P$. grandis, respectively. Natural products presented significant antifungal activity, with MIC values ranging from $0.078 \mathrm{mg} / \mathrm{mL}$ to $0.31 \mathrm{mg} / \mathrm{mL}$ for all strains, indicating its potential for use in preventive veterinary medicine to treat dermatophytosis (Ribeiro et al., 2018).

Effect of essential oils from Mangifera indica L. cultivars on the antifungal susceptibility of Candida spp. strains isolated from dogs. Tommy Atkins cultivar presented $\beta$-selinene (29.49\%), caryophyllene oxide (12.40\%) and humulene II epoxide (8.66\%) as main constituents, while the main constituents of Rosa, Moscatel and Jasmim varieties were caryophyllene oxide (23.62, 48.42 and $30.77 \%$, respectively) and humulene epoxide II (11.56, 23.45, and16.27\%, respectively). The means of inhibition zones were $11 \pm 0.71$, $13.5 \pm 3.54,10.5 \pm 0.71$ and $13.5 \pm 0.71 \mathrm{~mm}$ to Tommy Atkins, Rosa, Moscatel and Jasmim varieties, respectively. For Tommy Atkins, the MIC ranged from 0.62 to $1.25 \mathrm{mg} / \mathrm{mL}$; for Rosa, ranged from 0.31 to $1.25 \mathrm{mg} / \mathrm{mL}$; for Jasmim ranged from 0.31 to $0.62 \mathrm{mg} / \mathrm{mL}$; while for the Moscatel variety the MIC value was $1.25 \mathrm{mg} / \mathrm{mL}$ for all Candida strains. Essential oils of four $M$. indica cultivars were active in vitro against Candida spp., demonstrating good antifungal activity and can be a useful source of antifungal compounds for veterinary medicine (Fontenelle et al., 2017).

The essential oil of Coriandrum sativum L. fruits presented Linalool as the main constituent (58.22\%). The oil was considered bioactive, showing an $\mathrm{LC}_{50}$ value of 23 $\mu \mathrm{g} / \mathrm{mL}$ in the Artemia salina lethality test. The antifungal activity was evaluated against 
Microsporum canis and Candida spp. by the agar-well diffusion method and the minimum inhibitory concentration (MIC) and the minimum fungicidal concentration (MFC) were established by the broth microdilution method. The essential oil induced growth inhibition zones of $28 \pm 5.42$ and $9.25 \pm 0.5$ for $M$. canis and Candida spp. respectively. The MICs and MFCs for M. canis strains ranged from 78 to 620 and 150 to 1,250 $\mu \mathrm{g} / \mathrm{mL}$, and the MICs and MFCs for Candida spp strains ranged from 310 to 620 and 620 to 1,250 $\mu \mathrm{g} / \mathrm{mL}$, respectively. C. sativum essential oil is active in vitro against $M$. canis and Candida spp. demonstrating good antifungal activity. (Soares et al., 2012).

\subsection{ANTILEISHMANIAL ACTIVITY}

The increased incidence of visceral leishmaniasis (VL) in Brazil is due to a lack of effective disease control measures. In addition to that, no effective treatment exists for canine VL in response to synthetic drugs. In the search for new antileishmanial agents, essential oils (Eos) from four Croton species (C. argyrophylloides, C. jacobinensis, C. nepetifolius and C. sincorensis) were evaluated against Leishmania infantum chagasi, $L$. amazonensis and L. braziliensis. Spathulenol, $\beta$-caryophyllene, $\beta$-caryophyllene oxide, 1,8-cineole and methyl eugenol were the major constituents. The in silico analysis revealed that 1,8-cineole and spathulenol (Figure 5.3) were active against the enzyme Leishmania infantum trypanothione reductase (LiTR), which is responsible for the redox defense of Leishmania in mammals, making both compounds promising agents for leishmaniasis control (Morais et al, 2019).

Figure 5.3. Active antileishmanial compounds from Croton species essential oil

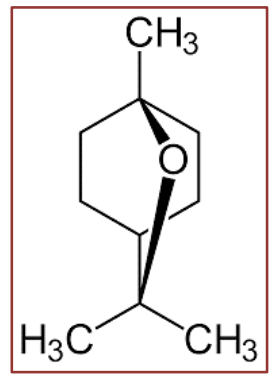

1,8-cineole

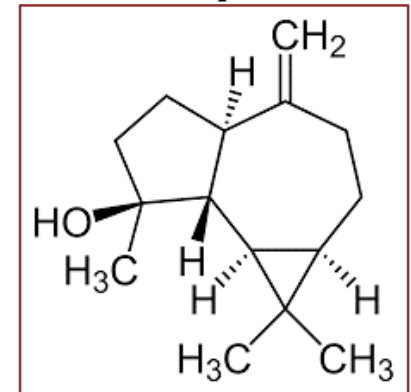

Spathulenol 
The compounds thymol and eugenol were chosen to be starting compounds to synthesize acetyl and benzoyl derivatives and to test their antileishmanial activity in vitro and in vivo against Leishmania infantum chagasi. The chemical structures are shown in figure 5.4. All compounds demonstrated similar activity against amastigotes, and acetyl-thymol was more active than thymol and the positive control drug amphotericin B. Immunohistochemistry demonstrated the presence of Leishmania amastigote only in the spleen but not the liver of mice treated with acetyl-thymol. Thus, these synthesized derivatives demonstrated anti-leishmanial activity both in vitro and in vivo. These may constitute useful compounds to generate new agents for treatment of leishmaniasis (Morais et al., 2014)

Figure 5.4. Representation of chemical structures of thymol and eugenol derivatives, antileishmanial agents

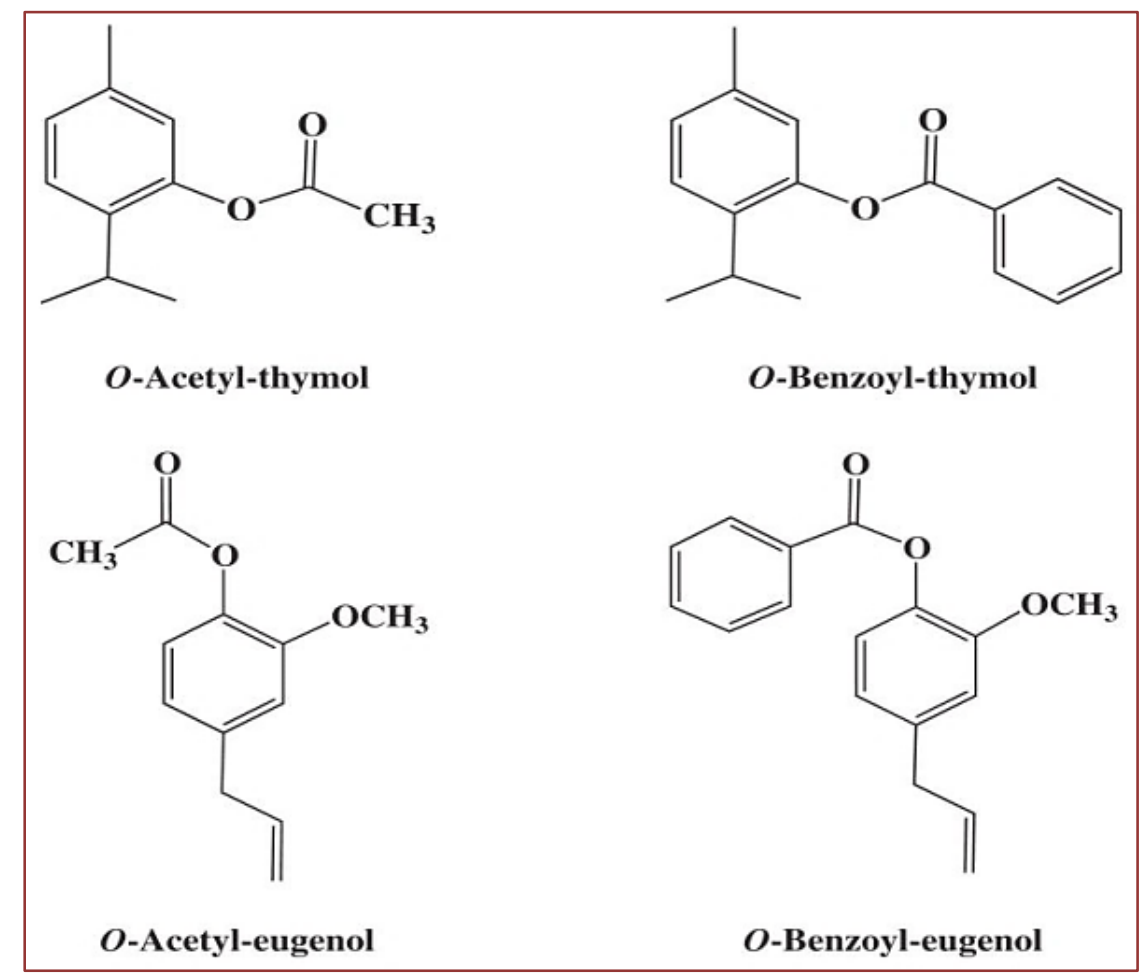

\subsection{ANTHELMINTIC ACTIVITY}

Phytotherapy can be an alternative for the control of gastrointestinal parasites of small ruminants. The efficacy of Alpinia zerumbet, Coriandrum sativum, Tagetes minuta and Lantana camara essential oils was demonstrated by two in vitro assays on Haemonchus contortus, an egg hatch test (EHT) and a larval development test (LDT). Chemical 
analysis identified components with high concentrations in these essential oils that may be responsible for their anthelmintic activity. The main component of $A$. zerumbet was 1,8-cineol, for L. camara was caryophyllene oxide, for $C$. sativum was linalool and the major constituent of T. minuta was piperitone. Based on the promising results presented in these in vitro models, it may be possible use these essential oils to control gastrointestinal nematodes. However, their anthelmintic activity should be confirmed in vivo (Macedo et al., 2013).

Thymol is a monoterpene and the acetylation form of this compound present lower toxicity. Thymol and 0-acetyl-thymol (Figure 7) were assayed on egg, larva and adult Haemonchus contortus and the cuticular changes, acute toxicity in mice and the efficacy on sheep gastrointestinal nematodes. In in vitro tests thymol presented better anthelmintic activity than TA. However, TA was less toxic and in in vivo test efficacy was similar (André et al., 2017).

Carvacrol is a compound present in several essential oils and it has been reported to possess anthelmintic activity. Acetylation of this monoterpene has been proposed as a potential way to reduce the toxicity and enhance the pharmacological effects of carvacrol. The effect of $O$-acetyl-carvacrol (Figure 5.6) was evaluated using in vitro and in vivo assays with gastrointestinal nematodes of small ruminants. AC showed in vitro and in vivo anthelmintic activity and was less toxic than carvacrol (André et al., 2016).

Figure 5.6. Chemical representation of anthelmintic aromatic monoterpenes and acetylderivatives

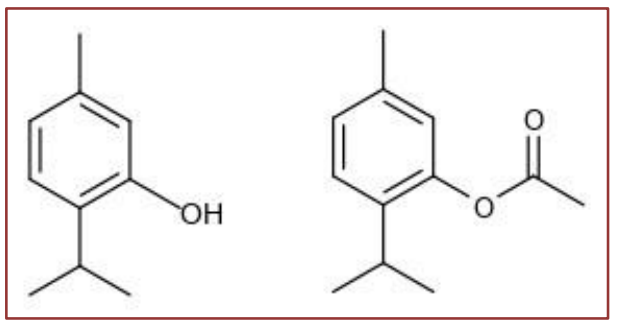

Thymol

O-acetyl-thymol

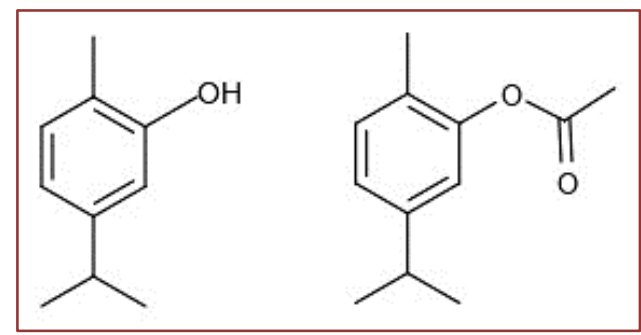

Carvacrol O-Acetyl-carvacrol

The anthelmintic activity of Eucalyptus citriodora essential oil and citronellal was observed on sheep gastrointestinal nematodes. Essential oil composition was 
determined by gas chromatography mass spectrometry. The acute toxicity test in mice and the fecal egg count reduction test (FECRT) in sheep were performed. Citronellal was confirmed as the essential oil major constituent (63.9\%). The essential oil and citronellal completely inhibited Haemonchus contortus motility at $6 \mathrm{~h}$ post exposure. H. contortus exposed to essential oil and citronellal exhibited internal ultrastructural modifications (Araújo-Filho et al., 2019).

On sheep gastrointestinal nematodes essential oils and its main constituents were tested obtaining good results as Eucalyptus citriodora essential oil and its major component, citronellal (Araújo-Filho et al., 2019) and Ocimum gratissimim and eugenol (Pessoa et al., 2002).

\subsection{LARVICIDE AGAINST AEDES AEGYPTI}

The search for new insecticides to control dengue fever, chikungunya, and Zika vectors has gained relevance in the past decades. The larvicidal action of essential oils (EOs) from Thymus vulgaris, Salvia officinalis, Lippia origanoides, Eucalyptus globulus, Cymbopogon nardus, Cymbopogon martinii, Lippia alba, Pelargonium graveolens, Turnera diffusa, and Swinglea glutinosa on Aedes (Stegomyia) aegypti were evaluated. The EOs were extracted by microwave-assisted hydrodistillation and characterized by gas chromatography/mass spectrometry (GC/MS). All EOs achieved larvicidal activity at medium lethal concentration $\mathrm{LC}_{50}$ values lower than $115 \mathrm{mg} / \mathrm{L}$. The main compounds of the EOs with highest larvicidal activity were thymol (42\%) and p-cymene (26.4\%) (Riós et al, 2017).

The essential oil from Tagetes erecta was active against 3rd instars of Aedes and the main compounds were piperitone (45.72\%), D-limonene (9.67\%), and piperitenone (5.89\%). The essential oil of T. erecta present effective action and then constitutes a good source of varied compounds showing larvicidal activity against Ae. aegypti (Marques et al., 2011).

The essential oils from Cymbopogon citratus and Lippia sidoides, reported in the literature to have larvicidal properties against A. aegypti, were used for activity comparison. The results show that Ocimum americanum and Ocimum gratissimum have $\mathrm{LC}_{50}$ of $67 \mathrm{ppm}$ and $60 \mathrm{ppm}$ respectively, compared to $63 \mathrm{ppm}$ for L. sidoides and $69 \mathrm{ppm}$ 
for $C$. citratus. These good results suggest a potential utilization of the essential oil of these two Ocimum species for the control of Ae. aegypti (Cavalcanti et al, 2004).

Insecticidal activity of the essential oils (EOs) isolated from Tagetes lucida, Lippia alba, Lippia origanoides, Eucalyptus citriodora, Cymbopogon citratus, Cymbopogon flexuosus, Citrus sinensis, Swinglea glutinosa, and Cananga odorata aromatic plants, grown in Colombia (Bucaramanga, Santander), and of a mixture of L. alba and L. origanoides EOs were evaluated on Aedes (Stegomyia) aegypti Rockefeller larvae. The EOs were extracted by microwave-assisted hydrodistillation. All essential oils tested showed insecticidal activity. The EO from $C$. flexuosus, with citral (geranial+neral) as main component, showed the highest larvicidal activity (Viera et al., 2014).

The larvicidal activity of essential oils of four species of Piper from the Amazon Forest was tested using third-instar larvae of Aedes aegypti. The main components isolated from each Piper species were as follows: viridiflorol (27.50\%), aromadendrene (15.55\%) and $\beta$-selinene (10.50\%) from Piper gaudichaudianum; $\beta$-selinene $(15.77 \%)$ and caryophyllene oxide (16.63\%) from Piper humaytanum; dillapiol (54.70\%) and myristicin (25.61\%) from Piper permucronatum; and asaricin (27.37\%) and myristicin (20.26\%) from Piper hostmanianum. Amongst all essential oils tested, the most active against larvae of $A$. aegypti was the oil extracted from $P$. permucronatum, with a $\mathrm{LC}_{50}=36 \mu \mathrm{g} / \mathrm{ml} \quad\left(\mathrm{LC}_{90}=47 \mu \mathrm{g} / \mathrm{ml}\right)$, followed by the essential oil of $P$. hostmanianum, with a $\mathrm{LC}_{50}=54 \mu \mathrm{g} / \mathrm{ml}\left(\mathrm{LC}_{90}=72 \mu \mathrm{g} / \mathrm{ml}\right)$. The oils with higher content of arylpropanoids were more active against larvae of $A$. aegypti (Morais et al., 2007).

The essential oils from Cymbopogon citratus and Lippia sidoides, reported in the literature to have larvicidal properties against $A$. aegypti, were used for activity comparison. The results show that Ocimum americanum and Ocimum gratissimum have $\mathrm{LC}_{50}$ of $67 \mathrm{ppm}$ and $60 \mathrm{ppm}$ respectively, compared to $63 \mathrm{ppm}$ for L. sidoides and $69 \mathrm{ppm}$ for $C$. citratus. The essential oils of $O$. americanum (main constituent E-methylcinnamate) and 0. gratissimum (eugenol and 1,8-cineole) were shown to be as potent as L. sidoides and $C$. citratus in the larvicidal activity against A. aegypti and caused $100 \%$ mortality at a concentration of $100 \mathrm{ppm}$. These results suggest a potential utilization of the essential oil of these two Ocimum species for the control of A. aegypti (Morais et al, 2006). 


\subsection{IN AGRICULTURE}

The primary functions of volatiles appear to be to defend the plant against herbivores or pathogens or, by attracting pollinators and seed dispersers, to provide some reproductive advantage to plants. In the root system, there is also the production of volatile compounds that can act as antimicrobials, anti-herbivores or attract natural enemies of herbivores that feed on roots such as $\beta$-caryophyllene and 1,8-cineole. Methylated derivatives of phytohormones, such as methyl salicylate, methyl jasmonate and ethylene, for example, are released and negatively affect other plants, protecting the plant from competition. This process is known as allelopathy. Against the herbivory, volatile alcohols, aldehydes and esters with six carbon atoms as (Z)-3-hexenol, (E)-2hexanal e (Z)-3-acetato de hexenila are produced (Riffel \& Costa, 2015).

\subsection{AS ANTIOXIDANT}

General methodologies used in basic research evaluating antioxidant activity of natural products are by free radical capture methods DPPH (2,2-diphenyl-1-picrylhidrazil) (Rufino et al, 2007) and ABTS (S 2,2 AZINO BIS (3-ethylbenzo thiazoline 6 sulfonic acid, diammoninum salt) and by autoxidation of the FRAP and the $\beta$-carotene/linoleic acid system, comparing trolox and BHA standards as references (Rufino et al., 2006).

The antioxidant activity of volatile oils has been extensively studied and essential oils from Croton genre of Northeastern Brazil are considered potential sources of natural antioxidants. Essential oils of $C$. zenhtneri and C. nepetaefolius were evaluated as antioxidant by the modified methodology of thiobarbituric-reactive species and in general the oils of $C$. zenhtneri and C. argyrophylloides showed better action then $C$. nepetaefolius. The essential oils of $C$. zenhtneri and $C$. nepetaefolius present in their constitution monoterpenoids and sesquiterpenoids, as well as arylpropanoids; $C$. argyrophylloides oil has monoterpenoids and sesquiterpenoids, but does not contain arylpropanoids. The constituents E-anethole, anisyl formate, anisaldehyde, methyleugenol, 1,8-cineole, $\alpha$-pinene and spathulenol (Figure 5.7) were the main constituents of the essential oils studied (Morais et al., 2006). 
Figure 5.7. Main constituents of antioxidant essential oils from Croton species

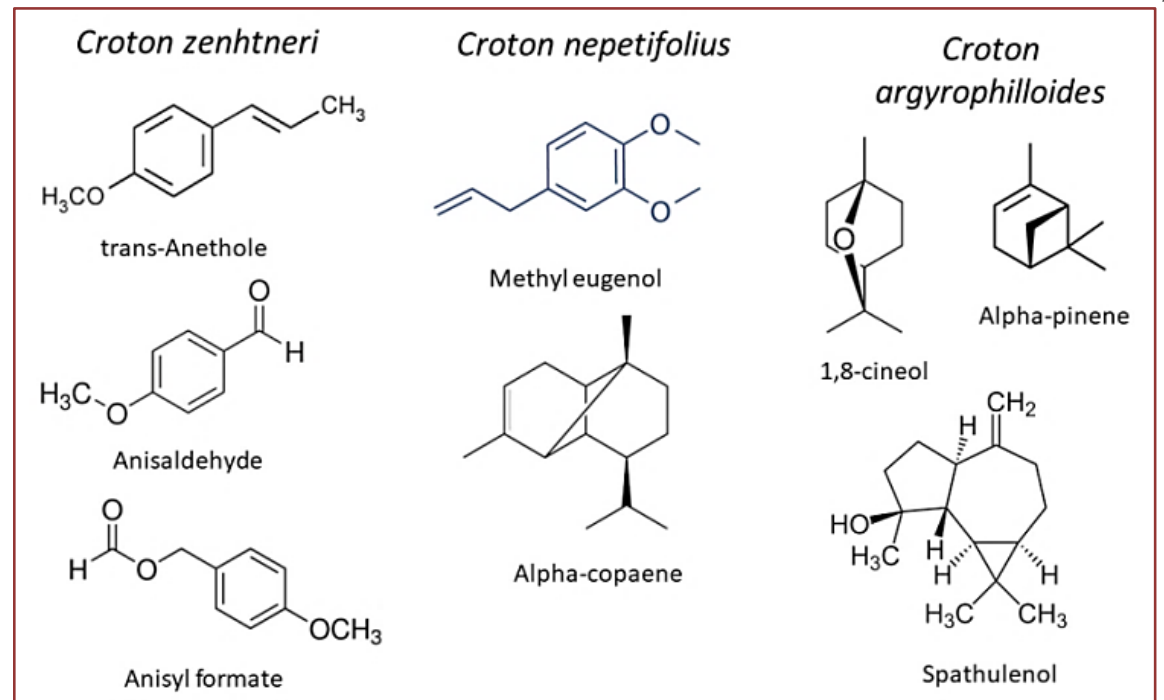

Some Eugenia essential oils have been reported as antioxidant and cytotoxic. The oil of Eugenia caryophyllata (clove) (syn. Syzygium aromaticum (L.) Merril \& Perry) is rich in eugenol and is a powerful natural antioxidant, with different mechanisms of action, such as radical scavenging, metals chelation, and the inhibition of lipid peroxidation. The high antioxidant activity observed for the Eugenia egensis oil (TEAC $=216.5 \pm 11.6 \mathrm{mg} \mathrm{TE} / \mathrm{mL}$ and $177.6 \pm 9.8 \mathrm{mg} \mathrm{BHAE} / \mathrm{mL}$ ) could be attributed to the oxygenated sesquiterpene 5hydroxy-cis-calamenene. The presence of a phenolic ring in the structure of 5-hydroxycis-calamenene as in eugenol molecule (Figure 5.8) enhances the antioxidant activity due to its ability for scavenging free radicals, the donation of hydrogen atoms or electrons, or chelation with metal cations (da Silva et al., 2017).

Figure 5.8. Structures of antioxidant constituents of Eugenia essential oils<smiles>C=CCc1ccc(O)c(OC)c1</smiles>

Eugenol

5-hydroxy-cis-calamenene

Several essential oils obtained by hydrodistillation from Mentha species showed higher levels of the monoterpenes limonene, isomenthone, menthol, menthofuran, $d$ neoisomenthol, 1,8-cineole (eucalyptol), d-carvone, linalool, linalyl acetate, piperitenone oxide and pulegone. The essential oil of Mentha longifolia (Himalayan silver mint) stood 
out for its antioxidant activity with $\mathrm{IC}_{50}$ of $0.86 \pm 0.01 \mathrm{mg} / \mathrm{mL}$ by the DPPH method (Barros et al., 2015).

\subsection{AS ANTITUMORAL}

Natural essential oil constituents play an important role in cancer prevention and treatment. Various mechanisms such antioxidant, antimutagenic and antiproliferative, enhancement of immune function and surveillance, enzyme induction and enhancing detoxification, modulation of multidrug resistance and synergistic mechanism of volatile constituents are responsible for their chemopreventive properties (Bhalla et al., 2013).

The antitumor action of terpenoids and phenylpropanoids is linked to the activation of the phenomena of cell death (apoptosis) in cancer cells without affecting normal cells. A very large number of studies suggest that natural terpenoids such as limonene constitutes a new class of anticancer drugs with the potential to cause tumor regressions with limited toxicity. Limonene is one of the most widespread monoterpene and is present in the majority of the EOs, in amounts up to $90 \%$ in lemon and citrus EO. In vitro and in vivo results suggest that limonene is effective against neuroblastoma and leukemia as well as other cancers from breast, liver, lungs, skin, stomach, and other organs. The efficacy of Geraniol, Thymol and Carvacrol, Farnesol, (-)- $\beta$-Elemene, (-)- $\alpha-$ Bisabolol, Thymoquinone, (-)- $\beta$-Caryophyllene, $\alpha$-Humulene, Nerolidol, Germacrone, Eugenol, has been demonstrated by numerous studies in vitro and in vivo on many cancers (Lesgards et al., 2014)

Girola and coworkers (2015) tested the antitumor properties of camphene isolated from the EO of Piper cernuum in melanoma cells. The study demonstrated that this compound was able to induce apoptosis through the caspase-3 pathway activation, as well as activating the endoplasmic reticulum (ER) stress signaling. Another study focused on the evaluation of the mechanism of action of carvacrol, a phenolic monoterpenoid abundant in the essential oils of oregano and thyme. In the metastatic breast cancer cell line MDAMB-231, carvacrol induced apoptosis via mitochondrial membrane permeabilization, resulting in cytochrome $\mathrm{C}$ release, induction of caspases indicated through poly ADP ribose polymerase (PARP) cleavage, and DNA fragmentation. $\alpha$-terpineol, a monoterpenoid alcohol, was able to downregulate the transcription of $\mathrm{NF} \kappa \mathrm{B}$ in a range of tumor cells, with the strongest inhibitory effect on small cell lung carcinoma cell line 
NCI-H69. Finally, $\alpha$-terpineol was further shown to have synergistic properties with another monoterpene, linalyl acetate, in colon cancer cells, inhibiting NF $\kappa \mathrm{B}$ expression and resulting in apoptosis (Blowman et al., 2018). Figure 5.9 show the chemical structures of active compounds with antitumoral activity.

Figure 5.9. Some antitumoral constituents from essential oils

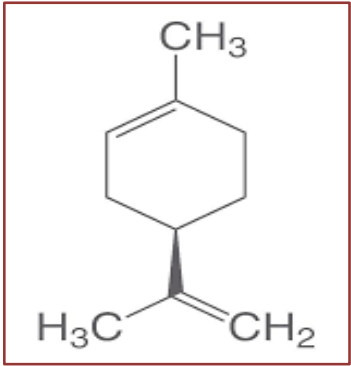

Limonene

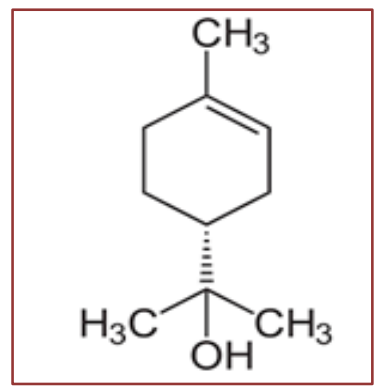

$\alpha$-Terpineol

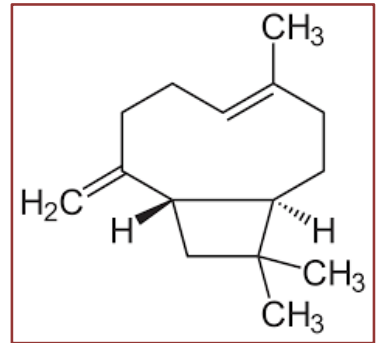

$\beta$-Caryophyllene<smiles>Cc1ccc(C(C)C)c(O)c1</smiles>

Thymol Carvacrol

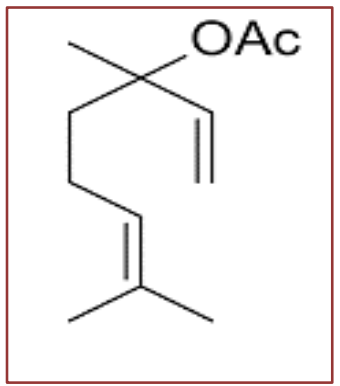

Linalyl acetate

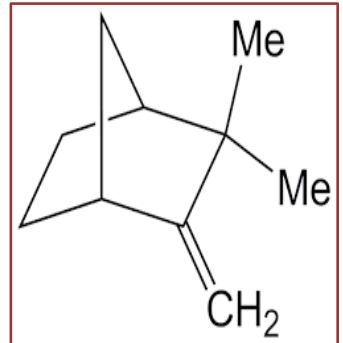

Camphene 


\section{REFERENCES}

Alves, F.A. Ribeiro; Morais, S.M. ; Sobrinho, A.C.N.; Silva, I.N.G.; Martins, C.G.; Silva, A.A.S.; Fontenelle, R.O.S. Chemical composition, antioxidant and antifungal activities of essential oils and extracts from Plectranthus spp. against dermatophytes fungi. Revista Brasileira de Saúde e Produção Animal (UFBA), v. 19, p. 105115, 2018.

André, W.P.P., Cavalcante, G. S., Ribeiro, W.L.C., Santos, J.M.L., Macedo, I.T.F., Paula, H.C.B., Morais, S.M., Melo, J.V.; Bevilaqua, C.M.L. Anthelmintic effect of thymol and thymol acetate on sheep gastrointestinal nematodes and their toxicity in mice. Revista Brasileira de Parasitologia Veterinária, v. 26, n.3, p. 323-330, 2017.

André, W.P.P.; Ribeiro, W. L.C.; Cavalcante, G. S.; Santos, Jessica M.L.D.; Macedo, I.T.F.; Paula, H.C.B.D.; Freitas, R.M.; Morais, S.M.; Melo, J.V.; Bevilaqua, C.M.L. Comparative efficacy and toxic effects of carvacryl acetate and carvacrol on sheep gastrointestinal nematodes and mice. Veterinary Parasitology, v. 218, p. 52-58, 2016.

Araújo-Filho, J.V.,Ribeiro, W.L.C., André, W.P.P., Cavalcante, G.S., Rios, T. T., Schwinden, G.M., Rocha, L.O., Macedo, I.T.F., Morais, S.M., Bevilaqua, C. M.L., Oliveira, L.M.B. Anthelmintic activity of Eucalyptus citriodora essential oil and its major component, citronellal, on sheep gastrointestinal nematodes. Revista Brasileira de Parasitologia Veterinária, v. 2, n. 8, p. 4, p. 644-651, 2019.

Aziz, Z.A.A.; Ahmad, A.; Setapar, S.H.M.; Karakucuk, A.; Azim, M.M.; Lokhat, D.; Rafatullah, M.; Ganash, M.; Kamal, M.A.; Ashraf, G.M. Essential Oils: Extraction Techniques, Pharmaceutical and Therapeutic Potential - A Review. Current Drug Metabolism, v. 19 p. 1100, 2018.

Bhalla, Y.; Gupta, V.K.; Jaitak, V. Anticancer activity of essential oils: a review. Journal of the Science of Food Agriculture, 93: 3643-3653, 2013.

Bandoni, A.L.; Mizrahi, I.; Juárez, M.A. Composition and Quality of the Essential Oil of Coriander (Coriandrum sativum L.) from Argentina. Journal of Essential Oil Research, v. 10, n. 5, p. 581-5, 1998.

Barbosa, L. C. A.; Demuner, A. J.; Clemente, A. D.; Paula, V. F.; Ismail, F. M. D. Seasonal variation in the composition of volatile oils from Schinus terebinthifolius Raddi. Química Nova, v. 30, n. 8, p. 1959-1965, 2007.

Barros, A.S.; Morais, S.M.; Ferreira, P.A.T.; Vieira, Í.G.P.; Craveiro, A.A.; Fontenelle, R.O.S.; Menezes, I.G.P.; Silva, F.W.F.; Sousa, H.A. Chemical composition and functional properties of essential oils from Mentha species. Industrial Crops and Products, v. 76, p. 557-564, 2015.

Borges, R. S.; Ortiz, B. L. S.; Pereira, A. C. M.; Keita, H.; Carvalho, J. C. T. Rosmarinus officinalis essential oil: A review of its phytochemistry, anti-inflammatory activity, and mechanisms of action involved. Journal of Ethnopharmacology, v. 229, p. 29-45, 2019.

Blowman, K.; Magalhães, M.; Lemos, M.; Cabral, C.; Pires, I.M. Anticancer Properties of Essential Oils and Other Natural Products. Evidence-based complementary and alternative medicine: eCAM, 2018, 3149362, 2018.

Cavalcanti E.S B.; Morais S.M.; Lima, M.A.A., Santana, E.W.P. Larvicidal Activity of essential oils from Brazilian plants against Aedes aegypti L. Memórias do Instituto Oswaldo Cruz, v. 99, n. 5, p. 541-544, 2004.

Dannenberg, G.S.; Funck G.D.; Silva, W.P.; Fiorentini, A.M. Essential oil from pink pepper (Schinus terebinthifolius Raddi): Chemical composition, antibacterial activity and mechanism of action. Food Control, 95, p115-120, 2019.

Diab, Y.; Auezova, L.; Chebib, H.; Chalchat, J-C.; Figueredo, G. Chemical Composition of Lebanese Rosemary (Rosmarinus officinalis L.) Essential Oil as a Function of the Geographical Region and the Harvest Time. Journal of Essential Oil Research, v. 14, n. 6, 449-452, 2002.

El-Baroty, G.S.; Abd El-Baky, H.H.; Farag, R.S.; Saleh, M.A. Characterization of antioxidant and antimicrobial compounds of cinnamon and ginger essential oils. African Journal of Biochemistry Research, v. 4, n. 6, p. 167-174, 2010.

Fontenelle, R.O.S.; Morais, S.M.; Brito, E.H.S.; Kerntopf, M.R.; Brilhante, R. S. N. Cordeiro, R.A.; Tomé, A.R.; Queiroz, M.G.R.; Nascimento, N.R.F.; Sidrim, J.J.C.; Rocha, M.F.G. Chemical composition, toxicological aspects and antifungal activity of essential oil from Lippia sidoides Cham. Journal of Antimicrobial Chemotherapy, v. 59, n. 5, p. 934-940, 2007. 
Fontenelle, R.O.S.; Morais, S.M.; Brito, E. H.; Brilhante, R. S.; Cordeiro, R. A.; Lima, Y. C.; Brasil, N. V.; Monteiro, A.J.; Sidrim, J.J.; Rocha, M.F. Alkylphenol Activity against Candida spp. and Microsporum canis: A Focus on the Antifungal Activity of Thymol, Eugenol and $O$-Methyl Derivatives. Molecules, 2011.

Fontenelle, R.O.S.; Nogueira-Sobrinho, A.C.; Soares, B.V.; Aguiar, F.L.L.; Brito, E.H.S.; Cavalcante, C.S.P.; Rocha, M F.G.; Morais, S.M Effect of essential oils from Mangifera indica L. cultivars on the antifungal susceptibility of Candida spp. strains isolated from dogs. Revista Brasileira de Saúde e Produção Animal (UFBA), v. 18, p. 337-346, 2017.

Hussain, A.I.; Anwar, F.; Chatha, S.A., Jabbar, A.; Mahboob, S.; Nigam, P.S. Rosmarinus officinalis essential oil: antiproliferative, antioxidant and antibacterial activities. Brazilian journal of microbiology, v. 41(4), p. 1070-1078, 2010.

Joshi, R. K.; Hoti, S. (2014). Chemical composition of the essential oil of Ocimum tenuiflorum L. (Krishna Tulsi) from North West Karnataka, India. Plant Science Today. 1. 99-102. 10.14719/pst.2014.1.3.52.

Kavoosi, G.; Rabiei, F. Zataria multiflora: chemical and biological diversity in the essential oil. Journal of Essential Oil Research, v. 27, n. 5, p. 428-436, 2015.

Komaitis, M.; Ifanti-Papatragianni, N.; Melissari-Panagiotou, E. Composition of the essential oil of marjoram (Origanum majorana L.). Food Chemistry, v. 45, p. 117-118, 1992.

Leyva-López, N.; Gutiérrez-Grijalva, E.P.; Vazquez-Olivo, G.; Heredia, J.B. Essential Oils of Oregano: Biological Activity beyond their Antimicrobial Properties. Molecules (Basel, Switzerland), v. 22, n. 6, p. 989, 2017.

Lesgards, J.-F.; Baldovini, N.; Vidal, N.; Pietri, S. Anticancer Activities of Essential Oils Constituents and Synergy with Conventional Therapies: A Review. Phytother. Res. 28: 14231446, 2014.

Macedo, I.T.F.; Oliveira, L.M.B.; Camurça-Vasconcelos, A.L.F.; Ribeiro, W.L. C.; Santos, J.M.L.; Morais, S.M. ; Paula, H.C.B.; Bevilaqua, C.M.L. In vitro effects of Coriandrum sativum, Tagetes minuta, Alpinia zerumbet and Lantana camara essential oils on Haemonchus contortus. Revista Brasileira de Parasitologia Veterinária, v. 22, p. 463-469, 2013.

Maciel, M.V.; Morais, S.M.; Bevilaqua, C.M.L.; Silva, R.A; Barros, R.S.; Sousa, R.N.; Sousa, L.C.; Brito, E.S.; Souza-Neto, M.A. Chemical composition of Eucalyptus spp. essential oils and their insecticidal effects on Lutzomyia longipalpis. Veterinary Parasitology, v.167, p. 1-7, 2010.

Marques, M.M.M.; Morais, S.M.; Vieira, Í.G.P.; Vieira, M.G.S.; Silva, A.R.A.; De Almeida, R.R.; Guedes, M.I.F. Larvicidal Activity of Tagetes erecta Against Aedes aegypti. Journal of the American Mosquito Control Association, v. 27, p. 156-158, 2011.

Marriot, P. J.; Shellie, R.; Cornwell C. Gas chromatographic technologies for the analysis of essential oils. Journal of Chromatography A, 936 (2001) 1-22

Mejri, J., Aydi, A., Abderrabba, M., Mejri, M. Emerging extraction processes of essential oils: A review. Asian Journal of Green Chemistry, 2018; 2(3): 246-267.

Morais, S.M.; Cossolosso, D.; Silva, A.A.; De Moraes, M.O.; Teixeira, M.J.; Campello, C.; Bonilla, O.H.; De Paula, V.; Vila-Nova, N. Essential Oils from Croton Species: Chemical Composition, in vitro and in silico Antileishmanial Evaluation, Antioxidant and Cytotoxicity Activities. Journal of The Brazilian Chemical Society, v. 1, p. 1-9, 2019.

Morais, S.M.; Vila-Nova, N.S.; Bevilaqua, C.M.L.; Rondon, F.C.; Lobo, C.H.; Moura, A.A.A.N.; Sales, A.D.; Rodrigues, A.P.R.; Figueredo, J.R.; Campello, C.C.; Wilson, M. E.; Andrade-Filho, H.F. Thymol and eugenol derivatives as potential antileishmanial agents. Bioorganic \& Medicinal Chemistry, v. 22, p. 6250-6255, 2014.

Morais, S.M.; Catunda Júnior, F.E.A.; Silva, A.R.A.; Martins Neto, J.S.; Rondina, D.; Cardoso, J.H.L. (2006). Atividade antioxidante de óleos essenciais de espécies de Croton do Nordeste do Brasil. Química Nova, v. 29, n. 5, p. 907-910, 2006.

Morais, S.M. ; Facundo, V. ; Bertini, L. ; Cavalcanti, E ; Anjos-Junior, J.; Ferreira, S.; Brito, E.; Souza-Neto, M. Chemical composition and larvicidal activity of essential oils from Piper species. Biochemical Systematics and Ecology, Estados Unidos, v. 35, p. 670-675, 2007. 
Morais, S. M.; Cavalcanti, E.S.B.; Bertini, L.M.; Oliveira, C.L.L.; Rodrigues, J.R.B.; Cardoso, J.H.L. Larvicidal Activity Of Essential Oils From Brazilian Croton Species against Aedes aegypti L. Journal of the American Mosquito Control Association, v. 22, n.2, p. 161-164, 2006.

Morten, H; Tina, M.; Rikke, M. Essential Oils in Food Preservation: Mode of Action, Synergies, and Interactions with Food Matrix Components, v. 3, n. 2, p. 1-24, 2012.

Njoroge, S.M.; Phi, N.T.L.; Sawamura, M. Chemical Composition of Peel Essential Oils of Sweet Oranges (Citrus sinensis) from Uganda and Rwanda. Journal of Essential Oil Bearing Plants, v. 12, n.1, p. 26-33, 2009

Pereira, E.J.P.; Vale, J.P.C.; Silva, P.T.; Lima, J.; Alves, D.; Costa, P.S.; Rodrigues, T.H.S.; Menezes, J.E.S.A.; Morais, S.M.; Bandeira, P.N.; Fontenelle, R.O.S.; Santos, H.S. Circadian rhythm, and antimicrobial and anticholinesterase activities of essential oils from Vitex gardneriana. Natural Product Communications. v. 13, p. 635-638, 2018.

Pessoa, L.M; Morais, S.M. ; Bevilaqua, C.M.L. Anthelmintic activity of essential oil of Ocimum gratissimim Linn. and eugenol against Haemonchus contortus. Veterinary Parasitology, Austrália, v. 109, p. 59-63, 2002.

Ríos, N.; Stashenko, E.E.; Duque, J.E. Evaluation of the insecticidal activity of essential oils and their mixtures against Aedes aegypti (Diptera: Culicidae). Revista Brasileira de Entomologia. v. 61, n. 4, p. 307 $311,2017$.

Rufino, M.S.M.; Alves, R.E.; Brito, E.S.; Mancini Filho, J.; Moreira, A.V.B. Metodologia científica: determinação da atividade antioxidante total em frutas no sistema beta-caroteno/ácido linoléico. Embrapa Comunicado Técnico 126, 2006.

Rufino, M.S.M.; Alves, R.E.; Brito, E.S.; Morais, S.M.; Sampaio, C.G.; Pérez-jiménez, J.; Saura-Calixto, F.D. Ministério da Agricultura, Pecuária Metodologia Científica: Determinação da Atividade Antioxidante Total em Frutas pela Captura do Radical Livre DPPH. Embrapa, Fortaleza, CE., 2007.

Rufino, M.S.M.; Alves, R.E.; Brito, E.S.; Morais, S.M.; Sampaio, C.G.; Pérez-jiménez, J.; Saura-Calixto, F.D. Metodologia Científica: Determinação da Atividade Antioxidante Total em Frutas pela Captura do Radical Livre ABTS. EMBRAPA. Comunicado Técnico on-line nํ 127. Fortaleza. 2007.

Silva, J.K.R.; Andrade, E.H.A.; Barreto, L.H.; da Silva, N.C.F.; Ribeiro A.F.; Montenegro, R.C.; Maia, J.G.S. Chemical Composition of Four Essential Oils of Eugenia from the Brazilian Amazon and their Cytotoxic and Antioxidant Activity. Medicines (Basel), v. 8, n. 4(3), p. 51, 2017.

Soares, B.V.; Morais, S.M.; Fontenelle, R.O.S.; Queiroz, V.A.; Vila-Nova, N.S. Pereira, C.M.C.; Brito, E.S.; Neto, M.A.S.; Brito, E.H.S.; Cavalcante, C.S.P.; Castelo-Branco, D.S.C.M.; Rocha, M.F.G. Antifungal Activity, Toxicity and Chemical Composition of the Essential Oil of Coriandrum sativum L. fruits. Molecules (Basel. Online), v. 17, p. 8439-8448, 2012.

Soares, B.V.; Morais, S.M.; Fontenelle, R.O.S.; Queiroz, V.A.; Vila-Nova, N.S.; Pereira, C. M.C.; Brito, E.S.; Neto, M.A.S.; Brito, E.H.S.; Cavalcante, C.S.P.; Castelo-Branco, D.S.C.M.; Rocha, M.F.G. Antifungal Activity, Toxicity and Chemical Composition of the Essential Oil of Coriandrum sativum L. fruits. Molecules, v. 17, p. 84398448, 2012.

Solberg, vein O.; Göransson, M.; Petersen, M. A.; Yndgaard, F.; Jeppson, S. Caraway essential oil composition and morphology: The role of location and genotype, Biochemical Systematics and Ecology, v. 66, p. 351$357,2016$.

Srivastava, A.K.; Srivastava, S.K.; Syamsundar, K.V. Bud and leaf essential oil composition of Syzygium aromaticum from India and Madagascar. Flavour and Fragrance Journal, v. 20, p. 51-53, 2005.

Vankar. P.S. Essential Oils and Fragrances from Natural Sources. Resonance, 2004.

Vera, S.S.; Zambrano, D.F.; Méndez-Sanchez, S.C.; Rodríguez-Sanabria, F.; Stashenko, E.E.; Luna, J.E.D. Essential oils with insecticidal activity against larvae of Aedes aegypti (Diptera: Culicidae). Parasitology Research, v. 113, n. 7, 2647-2654, 2014.

Vieira, P.R.N. ; Morais, S.M.; Ferreira. P.A.T.; Bezerra, F.H.Q.; Oliveira, I.R.; Silva, M.G.V. Chemical composition and antifungal activity of essential oils from Ocimum species. Industrial Crops and Products, v. 55, p. 267-271, 2014.

Villanueva, M.A., Torres, R.C., Başer, K.H.C., Özek, T. and Kürkçüoğlu, M. The composition of Manila elemi oil. Flavour and Fragrance Journal, v. 8, p. 35-37, 1993 
Wolffenbuttel, A.; Zamboni, A.; dos Santos, M.; Borille, B.T.; Augustin, O.; Mariotti, K.; Leal, M.; Limberger, R. Chemical Components of Citrus Essential Oils from Brazil. The Natural Products Journal, v 5. p. 14-27, 2015.

Yamani, H.A.; Pang, E.C.; Mantri, N.; Deighton, M.A. Antimicrobial Activity of Tulsi (Ocimum tenuiflorum) Essential Oil and Their Major Constituents against Three Species of Bacteria. Frontiers in microbiology, v. 7, Article 681, 2016.

Yildiz, H. Chemical Composition, Antimicrobial, and Antioxidant Activities of Essential Oil and Ethanol Extract of Coriandrum sativum L. Leaves from Turkey, International Journal of Food Properties, v. 19, n. 7, p. 1593-1603, 2016.

Ziosi, P.; Manfredini, S.; Vertuani, S.; Ruscetta, V.; Radice, M.; Sacchetti, G.; Bruni, R. Evaluating essential oils in cosmetics: Antioxidant capacity and functionality. Cosmetics \& Toiletries. v.125, p. 32-40, 2010. 


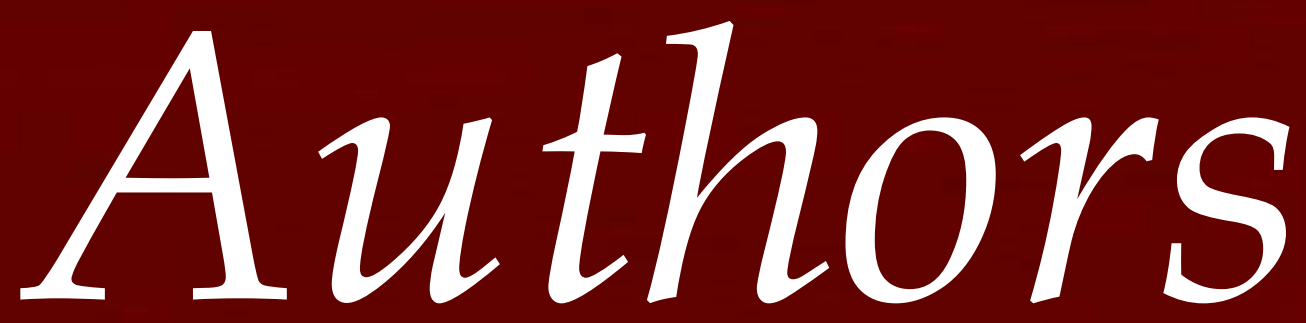




\section{Selene Maia de Morais (Organizer)}

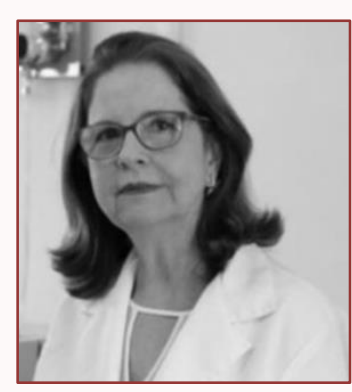

Graduated in Industrial Chemistry by the Federal University of Ceará, with a master's degree in Organic Chemistry at the Federal University of Ceará and a doctorate in Chemistry University of London (1991). Post-doctoral studies at the University of Aveiro (2015). She was a professor at the Federal University of Ceará until 1996, in undergraduate and graduate courses, exercising the positions of Coordinator of the Chemistry Course and Director of the Laboratory of Natural Products. She is currently a Full Professor at the State University of Ceará (UECE) and a CNPq productivity scholarship. She was coordinator of the Chemistry Course at UECE, participated in the Postgraduate Program in Physiological Sciences and currently guides students in the Doctoral Courses in Biotechnology at RENORBIO, in the Postgraduate Programs in Veterinary Sciences and Natural Sciences. He has experience in the Chemistry of Natural Products area, acting mainly in the isolation and structural determination of natural organic compounds and in the evaluation of their biological properties as antioxidant, leishmanicide, antiviral against the Dengue virus, antimicrobial, larvicide against Aedes aegypti, among others, working in together with researchers from the Veterinary Medicine, Biology and Medicine Courses. She is a reviewer of several national and international journals

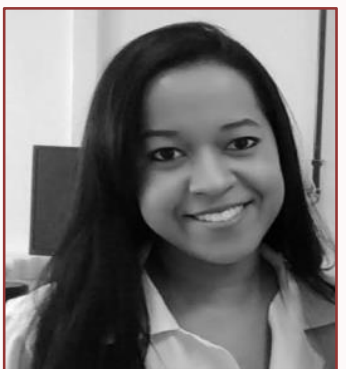

Ana Livya Moreira Rodrigues

Graduated in Chemistry from the State University of Ceará (UECE). She is currently a doctoral student in the Post-Graduate Program in Biotechnology - RENORBIO (UECE). Works with High Performance Liquid Chromatography (HPLC) analysis of phenolic compounds from plant extracts, cashew nut liquid, water-soluble and fatsoluble vitamins, gas chromatography analysis coupled to mass spectrometry (GC/ME) of essential oils, lipids and waxes. She has experience in the field of Natural Products, acting mainly on the following topics: Isolation and quantification of secondary metabolites with application in the pharmaceutical food and cosmetics industry. 


\section{Alexandre Sousa Barros}

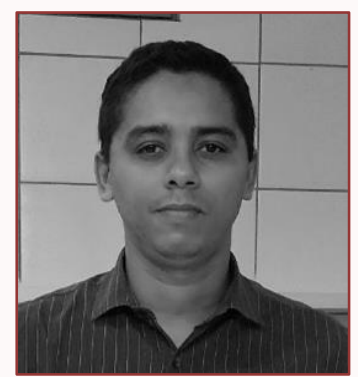

Doctorate in Biotechnology by the Northeast Biotechnology Network / UECE (2020), master's degree in Natural Resources from the Ceará State University (2015) graduation in Chemistry in Ceará State University (2006) and Specialist in School Management by Faculty of the Aldeia of Carapicuíba (2013). Has experience in the area of Chemistry, with an emphasis on Natural Products and Inorganic Chemistry, acting mainly on the following topics: Prospecting for natural products, essential oils, bioactive compounds, coordination compounds, natural products characterization, anticancer and anti-tuberculosis drugs, electrodeposition of metal alloys. Currently works as a teacher at the Ceará State Department of Education.

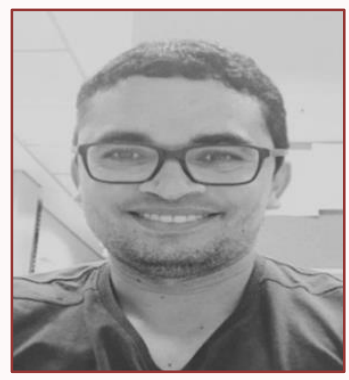

\section{Antonio Carlos Nogueira Sobrinho}

Graduated in Biological Sciences from the State University of Ceará (UECE), specialization in Inclusive Education (UECE), specialization in Human Physiology (Estácio de Sá), master's degree in Natural Resources (UECE) and doctorate in Biotechnology (UECE). Works with prospecting for natural products and teaching Biology. He has experience in the field of Natural Products, acting mainly on the following topics: antimicrobial sensitivity, antifungal and antiviral tests, toxicity of extracts and volatile oils, antioxidant tests, natural products of plant origin, essential oils and ethnobiological studies. Experience in Education, with an emphasis on Special Education, working mainly on the following themes: school inclusion, high skills / giftedness, science teaching, deaf education, and teaching-learning. He is currently a professor in the Biological Sciences Course at the State University of Ceará, based at the Faculty of Education, Sciences and Letters of Iguatu. He also currently holds a postdoctoral internship in the Graduate Program in Medical Sciences at the University of Fortaleza in the area of virology and molecular biology. 


\section{Celma de Oliveira Barbosa}

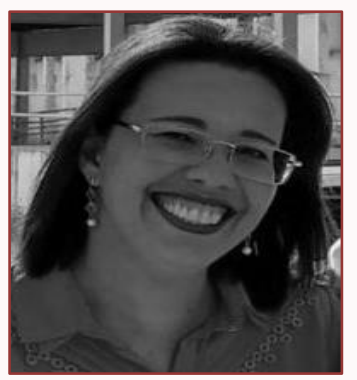

Doctorate in Biotechnology at the Federal University of Ceará (UFC); Master in Science and Health at the Federal University of Piauí (2008), Specialist in Food and Nutrition at the Federal University of Piauí (2005) and Specialist in Teaching from Higher Education at the FSA (2009), and graduated in Nutrition at the Federal University of Piauí (2003). Works as teacher in the area of chemical analysis of food and in the area of research I work in Food Science (Chemistry of foods and natural products) and Public Health. Research experiences: Essential oils; Spices; Chemical composition of food and development of food products; Bioactive compounds and antioxidant potential; Chemical analysis methods; Gerontology, Family Health Strategy; Chronic Noncommunicable Diseases and larvicidal activity against Aedes aegypt.

\section{Claudia Pessoa}

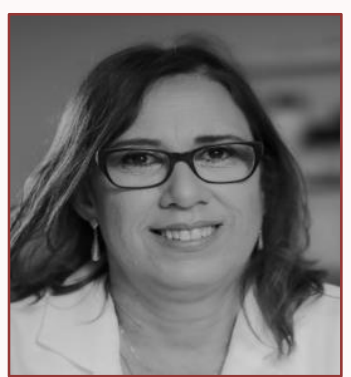

Full Professor of Physiology at the Department of Physiology and Pharmacology from the Federal University of Ceará (UFC). Researcher fellow from CNPq, level 1B. Undergraduation in Pharmacy from the Federal University of Pernambuco (1989), Master's degree and PhD in Pharmacology from UFC (1992), postdoctorate at the University of British Columbia (2008). Visiting researcher at the National Cancer Institute (NCI- USA) in 2000 and 2004. Senior visiting researcher at the John Curtin School of Medical Research - Australian National University, Canberra (2019). Head of the Natural Resources Area at RENORBIO Program (2007-2011). Vice-coordinator of the graduate program, focal point, RENORBIO at UFC (2019-2021). Currently, member of the Biotechnology Committee CA-BI/CNPq (2018-2023), besides the scientific and innovation technical evaluation and advisory chamber of the Foundation Ceará of Support to Scientific and Technological Development-FUNCAP (2018-2022). The main research activity is experimental oncology aiming the discovery of molecules (originated from the biodiversity, nature inspired or synthetic compounds) with anticancer potential. 


\section{Cleonilda Claita Carneiro Pinto}

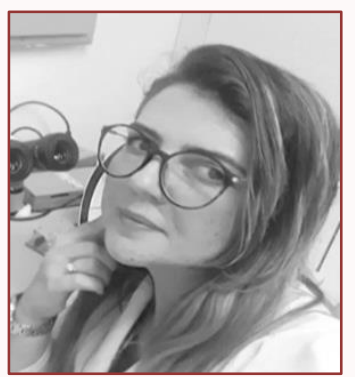

PhD student in Natural Sciences at the State University of Ceará. She holds a PhD (2019) and Master's (2015) degree in Veterinary Sciences and Specialization in Biochemistry and Molecular Biology Applied to the Health Area (2013) by the same institution, with a Degree in Biology (2008) from the State University Vale do Acaraú. She works in the area of Natural Products Chemistry, Biochemistry, Biology of Microorganisms and Molecular Biology, with an emphasis on anticholinesterase activity, synthesis of coordinated metal compounds, isolation and analysis of chemical constituents of plant species and microorganisms from the Caatinga with antioxidant, antifungal activities, anticancer, antileishmanial, and antiviral for Dengue, Zika and COVID-19. She was a Professor at the Ceará Department of Education and the Maracanaú City Hall.

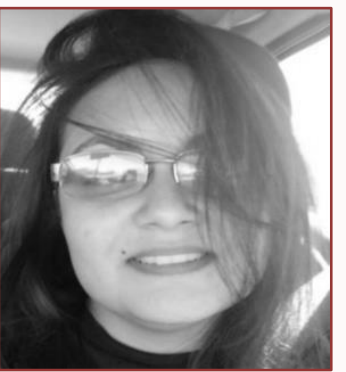

\section{Daniela Ribeiro Alves}

PhD student in Natural Sciences at the State University of Ceará. She holds a PhD (2019) and Master's (2015) degree in Veterinary Sciences and Specialization in Biochemistry and Molecular Biology Applied to the Health Area (2013) by the same institution, with a Degree in Biology (2008) from the State University Vale do Acaraú. She works in the area of Natural Products Chemistry, Biochemistry, Biology of Microorganisms and Molecular Biology, with an emphasis on anticholinesterase activity, synthesis of coordinated metal compounds, isolation and analysis of chemical constituents of plant species and microorganisms from the Caatinga with antioxidant, antifungal activities, anticancer, antileishmanial, and antiviral for Dengue, Zika and COVID-19. She was a Professor at the Ceará Department of Education and the Maracanaú City Hall. 


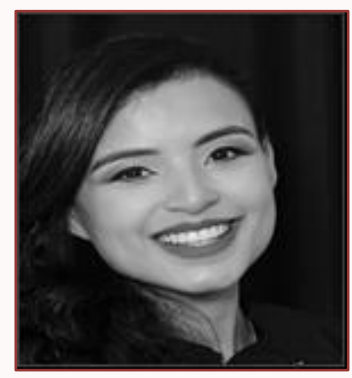

\section{Dayane Lima Guerra}

Bachelor of Biotechnology from the Federal University of Ceará (UFC)

2017.1. Effective member of the Integrated Student Qualification Program (PIQD) of the Biotechnology course 2013-2014. Director of Human Resources at the Junior Company of the Bachelor of Biotechnology, AUG BIOTEC, in the 2014-2015 management. Scholarship holder of the Institutional Program for Scientific Initiation Scholarships - PIBIC / CNPq at the Biocrystallography Laboratory 2014-2015. Intern at the Brazilian Agricultural Research Corporation (Embrapa), at the headquarters of Tropical Agriculture 2015-2017. Master in the Natural Sciences Program at the State University of Ceará March / 2018-December / 2019.

\section{Edilberto Rocha Silveira}

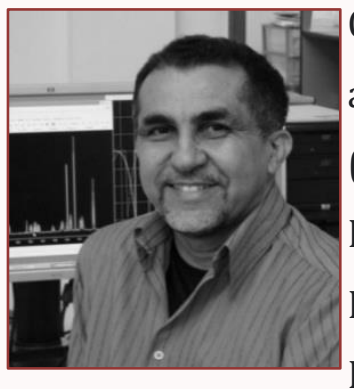

Graduated in Chemistry from the Federal University of Ceará (1975) and Bachelor in Chemistry from the Federal University of Ceará (1976). He completed a Master's Degree in Organic Chemistry from the Federal University of Ceará (1979), a Doctorate (Ph. D.) in Pharmacognosy - University of Mississippi (1985), and did a

Postdoctoral internship at Virginia Polytechnic Institute and State University-USA (1994). He is currently a researcher $1 \mathrm{~A}$ of the National Council for Scientific and Technological Development, participating, until June 2017, in three non-consecutive administrations, as a member of the CNPq Chemistry Advisory Committee, in the area of Natural Products Chemistry. Full Professor in Organic Chemistry of the Department of Organic and Inorganic Chemistry at the Federal University of Ceará, and was elected Full Member of the Brazilian Academy of Sciences in 2017. He was Head of the Department of Organic and Inorganic Chemistry and Course Coordinator. Member of the CAPES triennial Evaluation Committee, twice member of the committee for choosing the best CAPES Thesis, and representative of the Full Professors of the Science Center at CONSUNI-UFC. He has experience in the area of Chemistry, with an emphasis on Chemistry of Natural Products, acting mainly in the following areas: Plant Phytochemistry of Northeastern Flora, including volatile (essential oils) and non-volatile chemical constitution; in the Integrated and Interdisciplinary Study (Chemistry / Botany / Pharmacology / Agronomy) of Medicinal Plants, Application of Spectroscopic Techniques in Structural Determination of Secondary Metabolites, and Application and Use of Modern NMR Techniques. 


\section{Elthon Gois Ferreira}

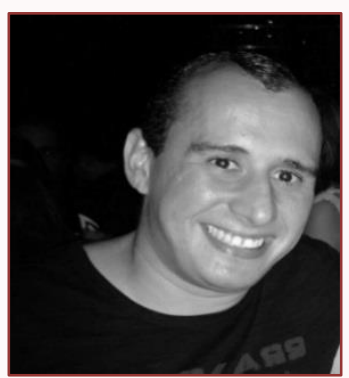

Graduated in Fisheries Engineering (2007) with Master in Tropical Marine Sciences (2010) and PhD in Tropical Marine Sciences (2014) by the Federal University of Ceará. Acts in the search for new drugs with anticancer activity through the prospecting of natural marine products with biological activity isolated from marine invertebrates and associated microorganisms.

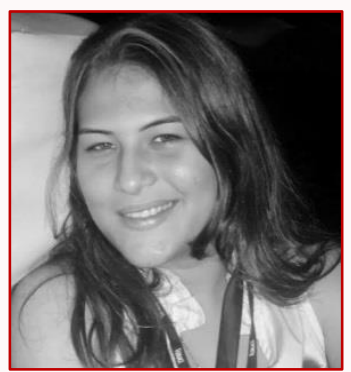

\section{Hortência Liberato}

Graduated in Full Degree in Chemistry from the State University of Ceará (UECE). Graduated at the technical level in the Environment course at the Federal Institute of Education, Science and Technology of Ceará (IFCE). Experience in chemical, physicalchemical, chemical analysis and evaluation of biological activity in natural products, as well as preparation of extracts, extraction of essential oils and natural pigments and phytochemical prospecting. Operation of equipment such as NIRFT, HPLC, Flame Photometer and Spectrophotometer. Knowledge in operating ICP-OES, CG-MS equipment. Experience in multivariate analysis and assembly of a chemometric model. Facilitator of short courses and workshops related to the area of solid waste management and environmental chemistry. Knowledge of quality management process and quality tools. Preparation of management documents, such as Technical Specifications for receiving raw material and standard for finished products, Technical Instructions for analysis and quality laboratory management, as well as preparation of analytical reports. Monitoring in internal audits and application of Good Manufacturing Practices (GMP) and Good Laboratory Practices (GLP). Currently work as quality control analyst in a pharmaceutical industry.

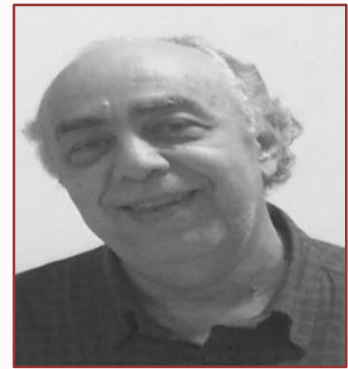

\section{Ícaro Gusmão Pinto Vieira}

Master's degree in Organic Chemistry - Department of Organic and Inorganic Chemistry (1990) and a PhD in Organic Chemistry from the Federal University of Ceará (2003). Experience in the area of Chemistry, with emphasis on Chemistry of Natural Products, acting mainly on the following topics: fine chemistry, organic syntheses, HPLC, chemistry of natural products, development of products and processes and methods for quality control. He is 
currently Visiting Professor of the Postgraduate Program in Natural Resources at UECE. Research activities at the Human Biochemistry Laboratories of the Nutrition Course at the Health Sciences Center - CCS as Collaborating Researcher and at the Natural Products Chemistry Laboratory of the Chemistry Course at UECE. Develops research and development activities at PADETEC and is a collaborating Professor in the Academic Master's Degree in Nutrition and Health at UECE.

\section{José Osvaldo Beserra Carioca}

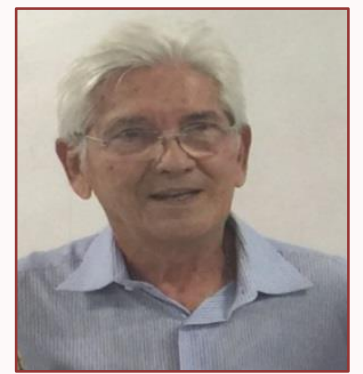

Graduation in Chemical Engineering from the Federal University of Ceará - UFC (1969), with a master's and doctorate in Chemical Engineering from the Federal University of Rio de Janeiro (1972 and 1976), respectively. He is an Associate Professor at UFC, based in the Department of Food Technology. He is a collaborator at the Ministry of the Environment, at the Luis de Queiroz Higher School of Agriculture, at Embrapa Agroindustry Tropical. He is a collaborating researcher at the Universities of Urbino (Italy) and Cologne (Germany), developing partnerships with the latter through the Institute of Technology of the Tropics (ITT). He has experience in the area of Chemical Engineering, with an emphasis on biotechnology, working mainly in the areas of bioenergy, biofuels and chemical processes of biomass. He is a professor of the Doctorate course at Rede Nordeste de Biotecnologia-RENORBIO, as well as the Master's course in Applied Physical Sciences-MCFA, at the State University of Ceará-UECE. Currently, coordinator of the Product and Process Development Laboratory - LDPP, located at PADETEC / UFC. He is a member of the Cearense Chemistry Academy. Member of the Coordination Committee of the Brazilian Green Chemistry Network. He is a member of the International Scientific Committee of the International Biotechnology Simposium-IBS Symposium (China / 2008; Italy / 2010; Korea / 2012; He is the Chairman of the 16th IBS, Brazil / 2014. He is a Member of the Scientific Committee of the European Federation of Biotechnology-EFB, Environmental biotechnology section, since 2011. Member of the Council for Environmental PoliciesCONPAM, of the Government of the State of Ceará, since 2008. He is a member of the Biotechnology Advisory Committee of IUPAC. 


\section{João Francisco Câmara Neto}

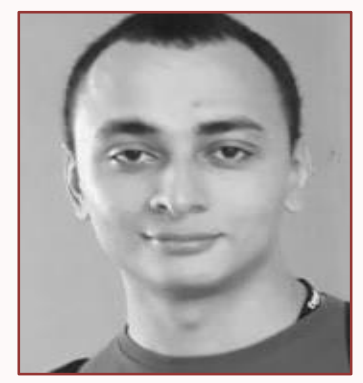

Graduated in Chemistry at the State University of Ceará - UECE. Has experience in the area of Chemistry, with emphasis on Chemistry of Natural Products. He was a monitor for two years of the discipline of Organic Chemistry I at the State University of Ceará - UECE, he was part of the Scientific Initiation group of the Laboratory of Chemistry of Natural Products (LQPN) of the Research Center in Animal Health - UECE. Master's degree completed by the Graduate Program in Chemistry at the Federal University of Ceará - UFC. Currently pursuing a Doctorate Course at UEC and being a member of the Laboratory of Polymers and Materials Innovation - LABPIM (UFC), working in the research line of natural polymers, with an emphasis on polysaccharides .

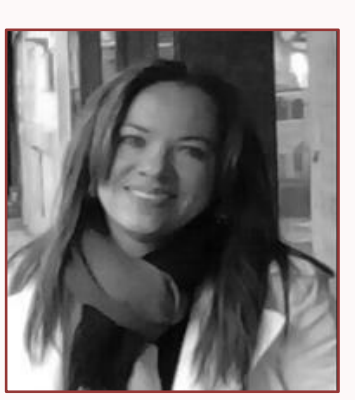

\section{Raquel Oliveira dos Santos Fontenelle}

Graduated in Biological Sciences from the University State of Ceará (2001), Bachelor's Degree in Biological Sciences from the State University of Ceará (2002), Master of Science Veterinarians at the State University of Ceará (2005), PhD in Veterinary Sciences by the State University of Ceará (2008) and Postdoctoral Degree in Molecular Genetics and Microorganisms focusing on application of basic techniques for diagnosis in pathogen research emerging and reemerging. She is currently an adjunct professor in the Biological Sciences at Vale do Acaraú State University, professor permanent degree of the Master and Doctorate in Natural Sciences of the University State of Ceará, Permanent Professor of the Master's Degree in Health Sciences from the Federal University of Ceará, Collaborating Professor of the Master's Degree in Zootechnics at the Universidade Vale do Acaraú State University and is a Research Productivity Fellow and Stimulus to Interiorization and Technological Innovation (BPI). Has experience in the area of Natural Products and Microbiology, acting mainly in the following topics: Bioprospecting of natural products. 


\section{Rita de Cassia Alves Pereira}

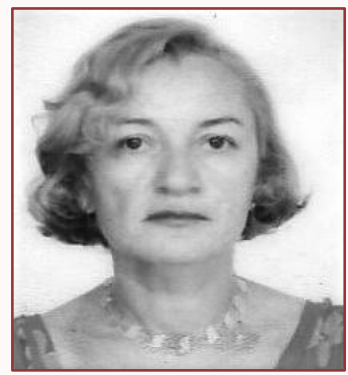

Graduated in Agronomic Engineering (1983) and Master in Agronomy (Fitotecnia) from the Federal University of Ceará (1994). PhD (Phytotechnics) from the Federal University of Lavras (2004) in the area of medicinal plants. Researcher at Embrapa Agroindustry Tropical since 1994. Experience in the area of Phytotechnics, with an emphasis on Plant Breeding, Plant Production and Management, working mainly on the following themes: medicinal, aromatic and seasoning plant.

\section{Vitor Carvalho Martins}

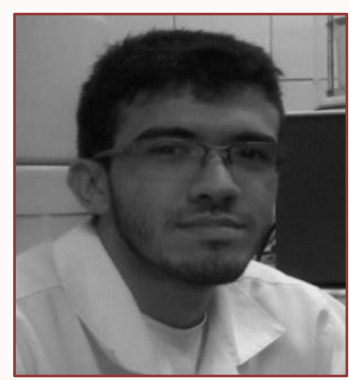

Master in Chemistry in Materials Chemistry field at the Federal University of Ceará, on the study of dielectric materials and dielectric properties. Graduated in Chemistry from the State University of Ceará (2016), with an emphasis on Chemistry of Natural Products, acting mainly in the study of extracts and essential oils of plants, mainly from Northeastern Brazil, in the main themes: antioxidants and toxicities in Artemia sp larvae. and Aedes aegypti. 


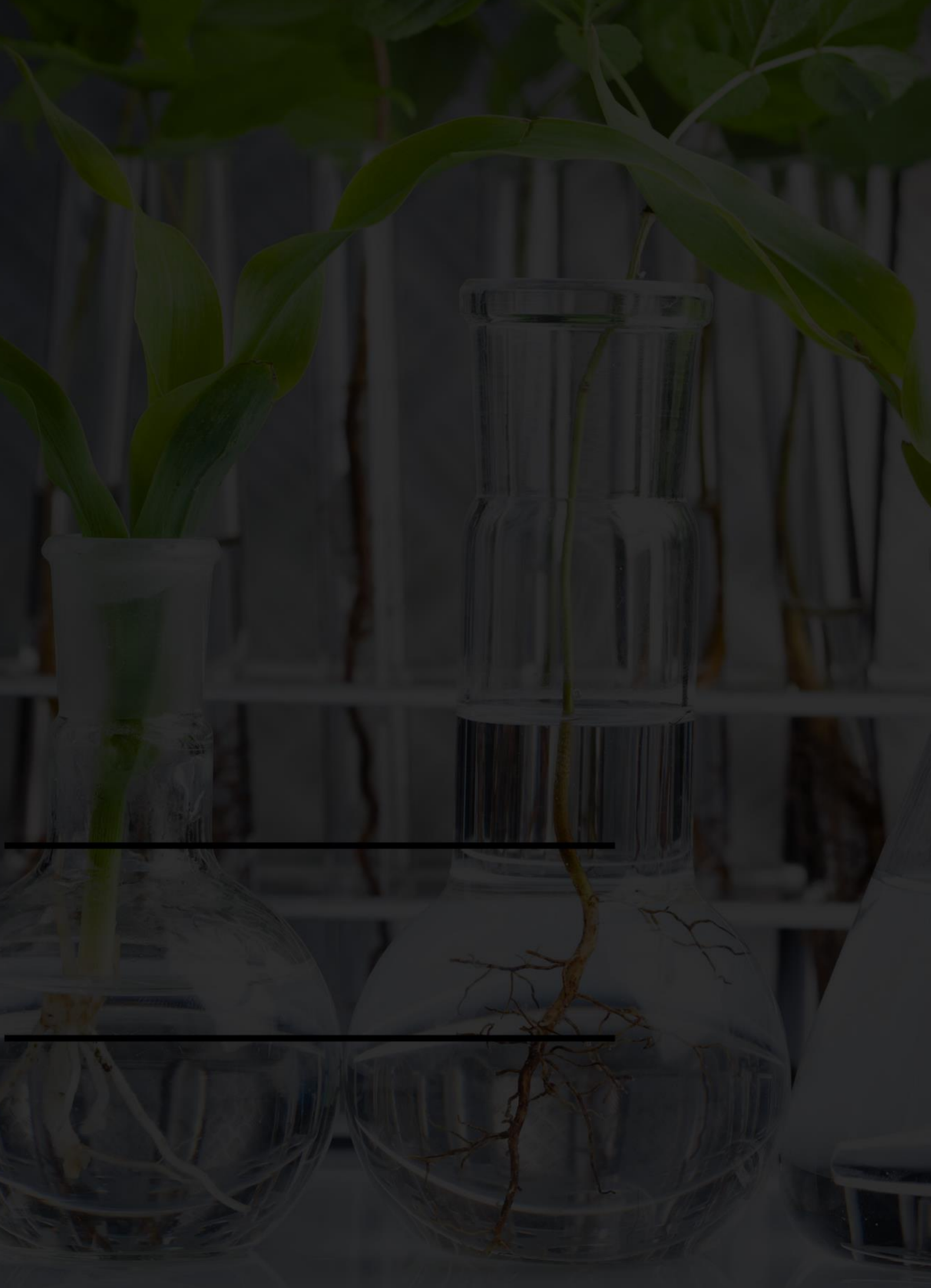

